\title{
COSTS AND THREATS OF INVASIVE SPECIES TO ALBERTA'S NATURAL RESOURCES
}


Digitized by the Internet Archive in 2016 
Costs and Threats of Invasive Species to Alberta's Natural Resources
A.S. McClay
K.M. Fry
E.J. Korpela
R.M. Lange
L.D. Roy

Alberta Research Council

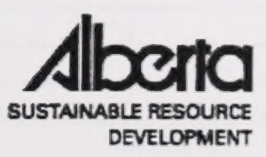

March 2004

Edmonton 


\section{DISCLAIMER}

This report is intended to provide Sustainable Resource Development staff with up-to-date information regarding the ecological and economic impacts of and potential threats from Alberta's invasive alien species.

The opinions, findings and recommendations expressed in this report are those of the authors and do not necessarily reflect the views of the government of Alberta.

For copies of this report, contact:

Information Centre

Main Floor, 9920108 Street

Edmonton, Alberta

CANADA T5K 2M4

Phone: (780) 944-0313

FAX: (780) 427-4407

Email: env.infocent@gov.ab.ca

ISBN No. 0-7785-2956-8 (Printed Edition)

ISBN No. 0-7785-2957-6 (On-line Edition)

Pub No. T/054 (Printed, On-line Edition) 


\section{TABLE OF CONTENTS}

LIST OF TABLES

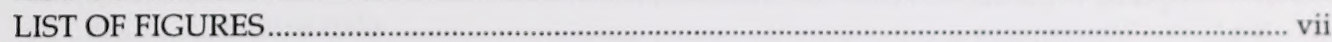

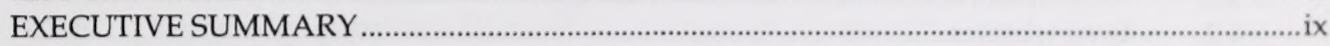

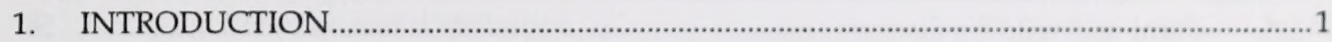

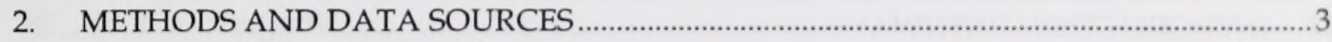

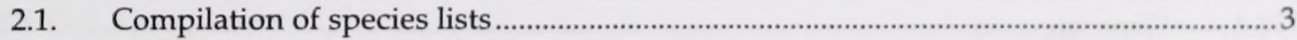

2.2. Selection of major invasive species in each category …...................................................

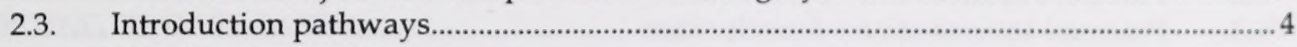

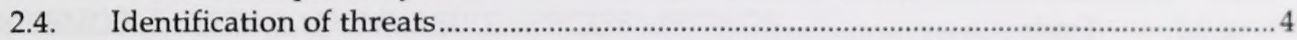

3. LISTING OF INVASIVE SPECIES CURRENTLY PRESENT IN ALBERTA .......................... 5

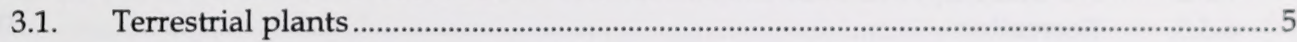

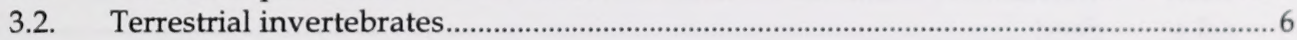

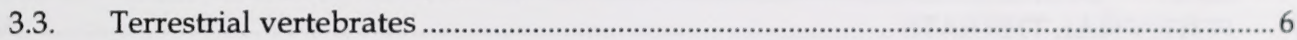

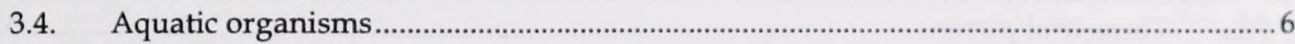

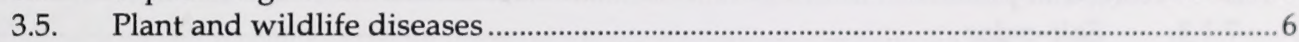

4. STATUS OF MAJOR INVASIVE SPECIES IN ALBERTA BY CATEGORY........................... 6

4.1. Terrestrial plants - non-agronomics ............................................................................

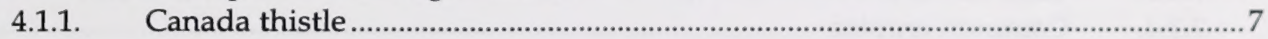

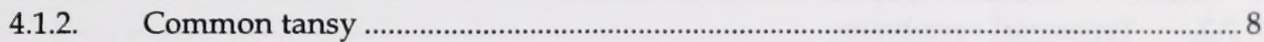

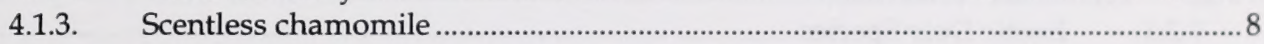

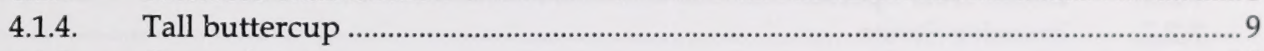

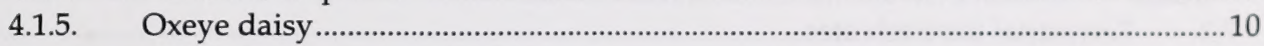

4.2. Terrestrial plants - escaped agronomics ................................................................. 11

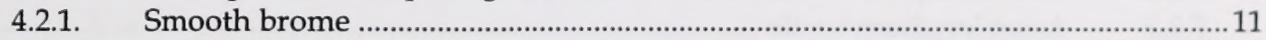

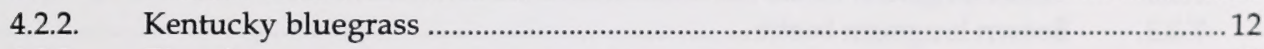

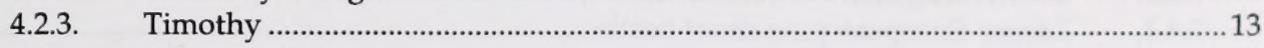

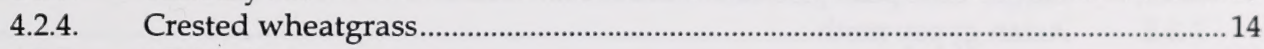

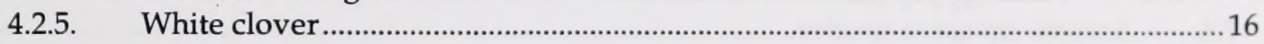

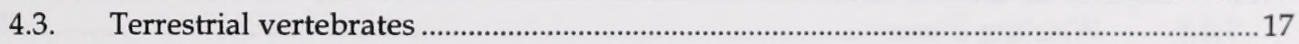

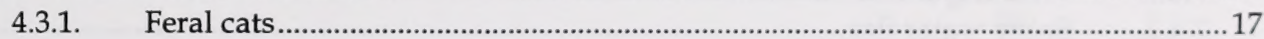

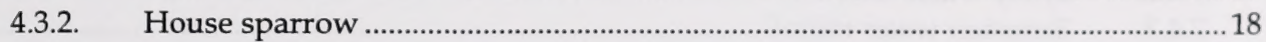

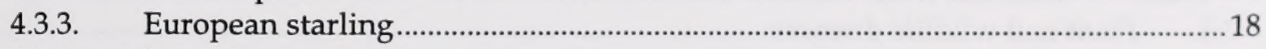

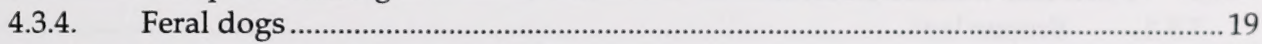

4.3.5. Norway and Black or Roof Rat ….................................................................... 19

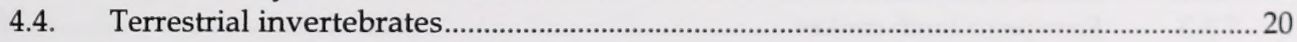

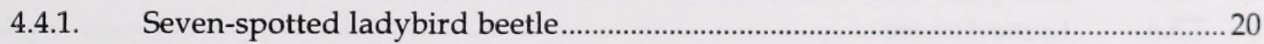

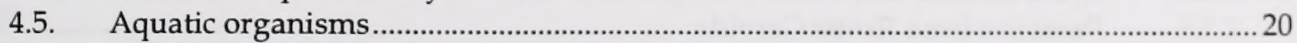

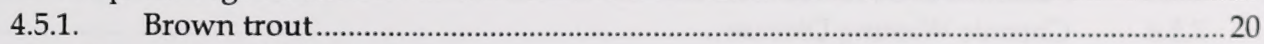

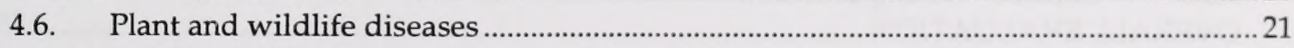

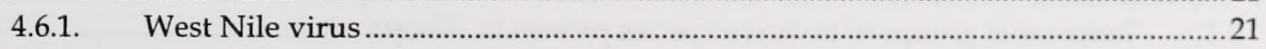

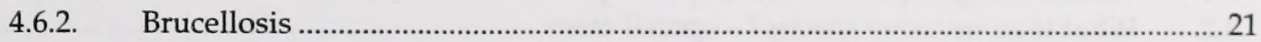

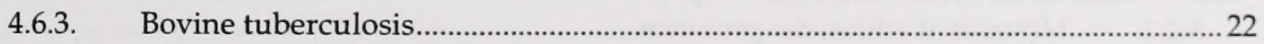

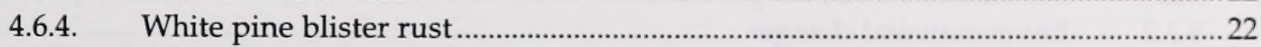

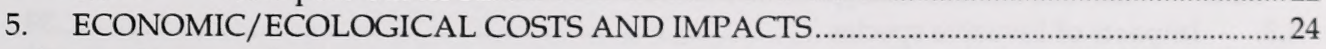

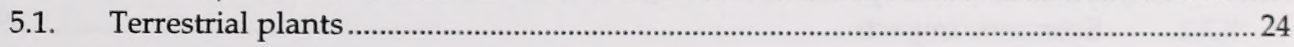




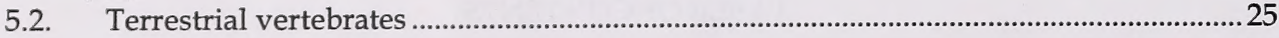

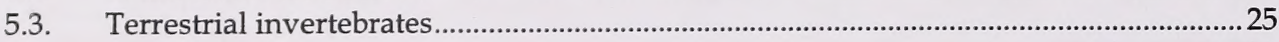

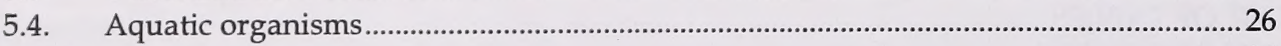

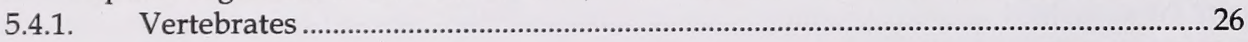

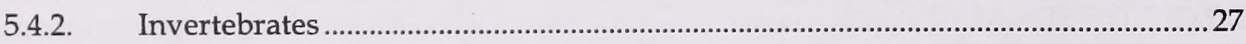

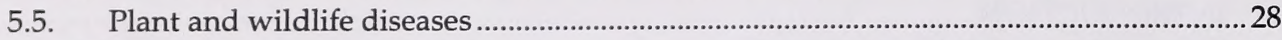

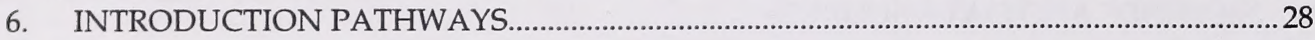

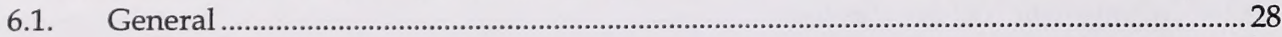

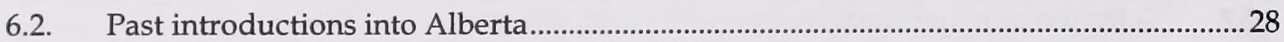

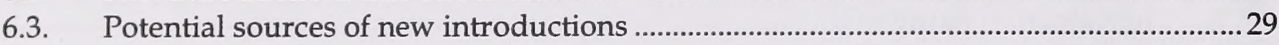

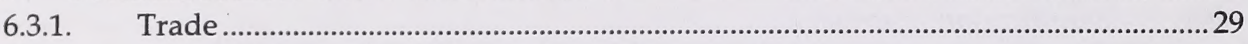

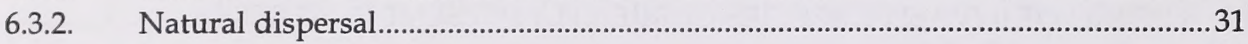

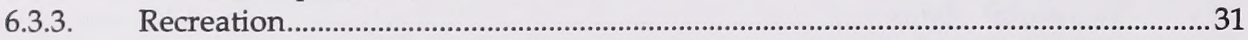

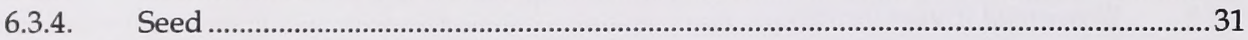

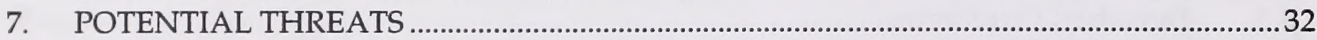

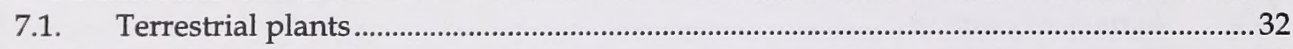

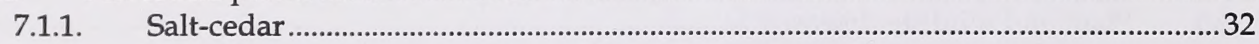

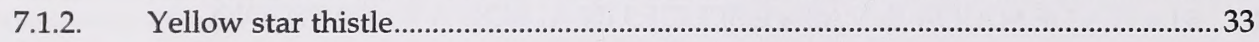

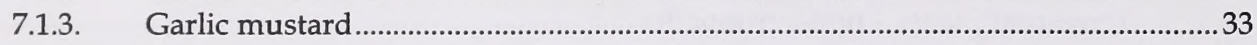

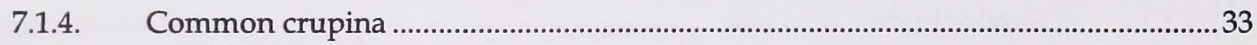

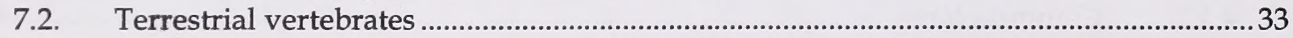

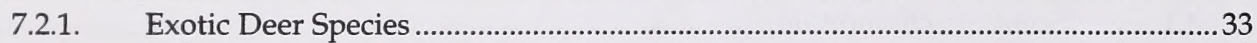

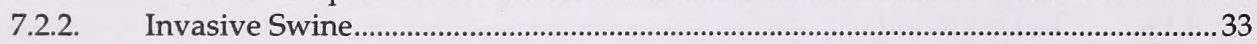

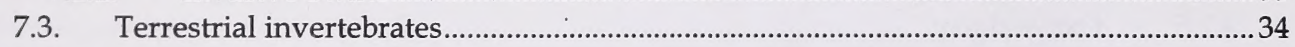

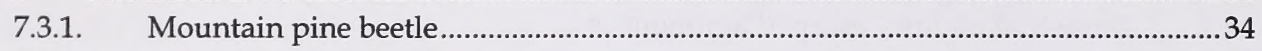

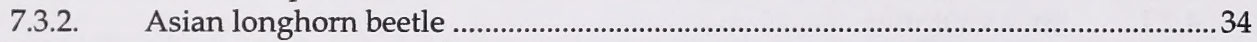

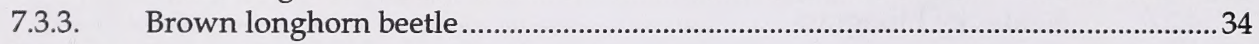

7.3.4. Larger European pine shoot beetle....................................................................... 34

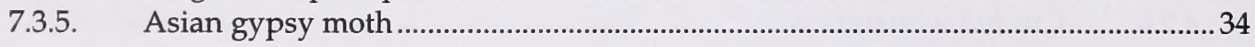

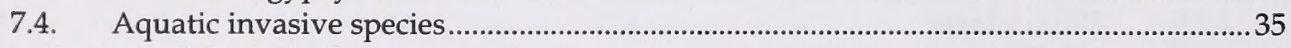

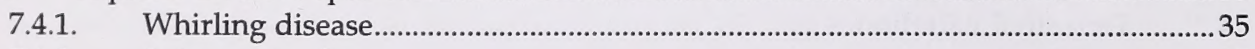

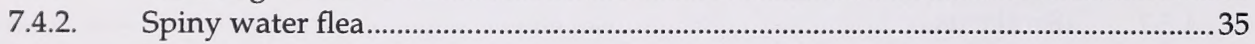

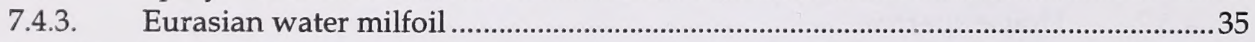

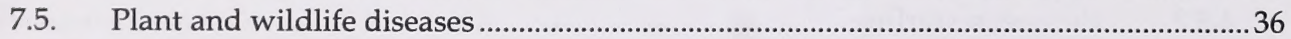

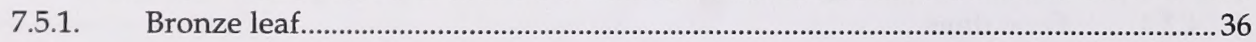

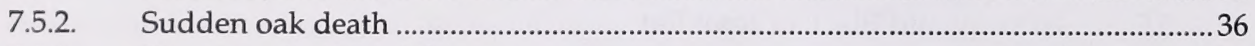

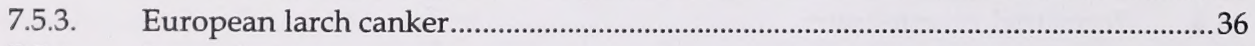

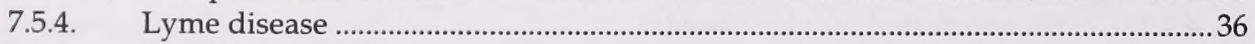

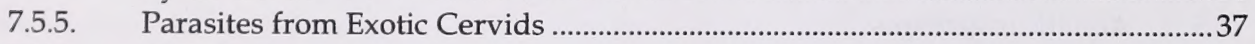

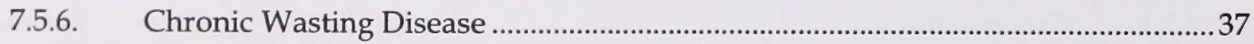

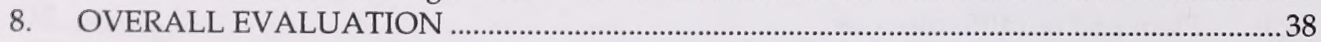

8.1. Taxonomic groups of invasive species present in Alberta ...............................................38

8.2. What is an invasive species? - special cases .................................................................. 38

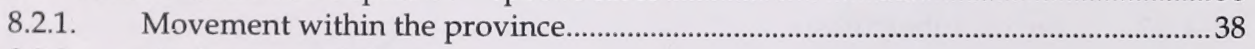

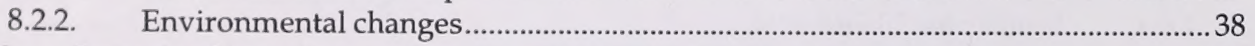

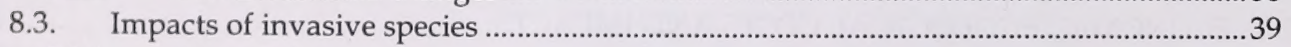

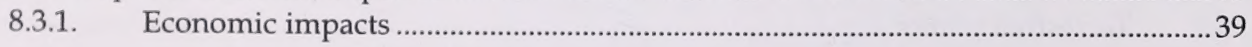




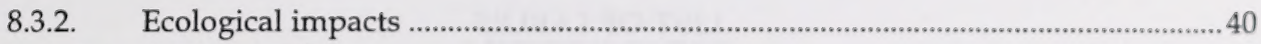

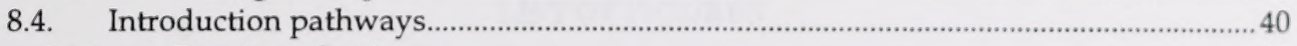

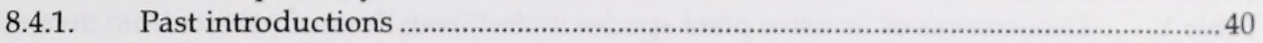

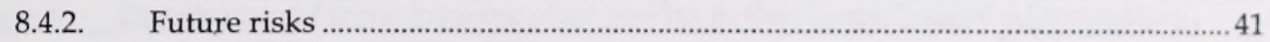

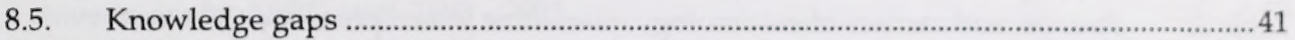

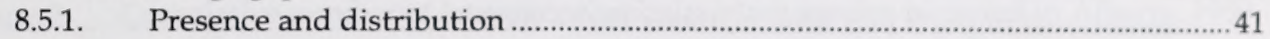

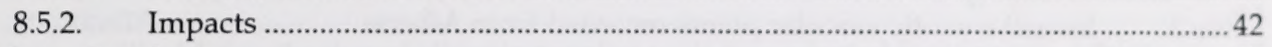

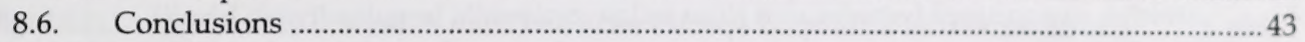

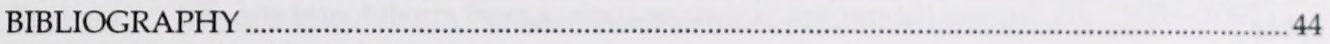

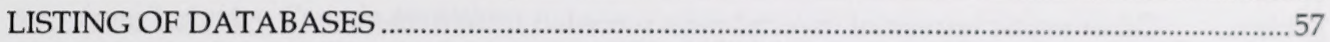

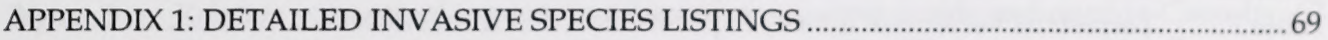

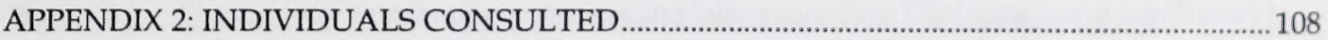




\section{LIST OF TABLES}

Table 1. Occurrences of invasive plant species in the Green Zone of Alberta from inventories by ASRD staff, 1998 - 2003. 61

Table 2. Sources and carriers of entomology quarantine interceptions by CFIA on

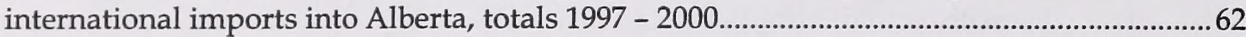

Table 3. Invasive exotic vascular plants recorded from Alberta ..............................................70

Table 4. Exotic terrestrial arthropod species recorded from Alberta........................................8 80

Table 5. Exotic terrestrial molluscs recorded from Alberta ......................................................93

Table 6. Other exotic terrestrial invertebrates recorded from Alberta .....................................94

Table 7. Terrestrial vertebrate invasive species recorded from Alberta..................................96

Table 8. Exotic fish species recorded from Alberta ...............................................................100

Table 9. Terrestrial invasive plant pathogens recorded from Alberta.................................... 101

Table 10. Exotic wildlife diseases recorded from Alberta ........................................................104 


\section{LIST OF FIGURES}

Figure 1. Distribution of some invasive plant species in the Green Zone of Alberta, from inventories by ASRD staff, 1998 - 2003.

Figure 2. Cumulative number of introduced vascular plant species recorded in Alberta, 1959 to present.

Figure 3. World distribution of climatic matches with five selected locations in Alberta. ......65

Figure 4. Imports into Alberta from various regions of the world, average for 1998 - 2002 from Industry Canada statistics. 66

Figure 5. Relative volumes of imports to Alberta from sources inside and outside Canada. .67 Figure 6. Entomology quarantine interceptions (also including Diplopoda and Mollusca) by Canadian Food Inspection Agency by province. 


\section{EXECUTIVE SUMMARY}

On the basis of available information, twenty-five non-native animal, plant, and microbial species were identified as the most significant invasive species affecting Alberta's natural resources.

Invasive plants are the most numerous and best documented invasives in Alberta, fifty species having been identified. Non-agronomic plants such as Canada thistle, common tansy, scentless chamomile, tall buttercup, and oxeye daisy are increasing in rangeland habitats in both the agricultural and green areas of Alberta, displacing native species and desirable forage plants. Some of these species are toxic or unpalatable to cattle and wildlife. Escaped agronomic species such as smooth brome, Kentucky bluegrass, timothy, crested wheatgrass, and white clover are dominant in some range types where native grasses would provide better grazing, and also invade native plant communities in conservation areas. Exotic plants may cause difficulty in reforestation if they invade logged areas.

There are relatively few invasive vertebrate species in Alberta, but the house sparrow and European starling are abundant and compete with native bird species for nest sites. Feral dogs and cats prey on native bird and mammal species. Norway and black rat numbers are kept low by eradication programs, but represent large potential damage to stored crops and human health. Several introduced sport fish (brown trout, brook trout, Yellowstone cutthroat trout, and rainbow trout) have extensively displaced and hybridized with native trout species along the Eastern Slopes.

Relatively little is known of the ecological effects of introduced arthropods and diseases in Alberta. The European seven-spotted lady beetle has displaced many native lady beetle species. White pine blister rust has had extensive impacts on whitebark and limber pine, with consequent ecosystem effects on species that depend on these pines. Brucellosis and bovine tuberculosis have had a serious impact on efforts to re-establish wood bison populations in northern Alberta, and are a potential threat to domestic livestock. West Nile virus has spread rapidly and may impact native bird populations, in addition to its human and animal health effects. (Note: bovine spongiform encephalopathy was not covered under the scope of this report.)

A review of potential threats and introduction pathways for invasive species in Alberta suggests that the province is most likely to receive new invasive species by spread from neighbouring areas, rather than being a primary introduction point for species from outside North America. Climate matching indicates that Europe and east Asia are also possible sources for new introductions.

A number of potential invaders were identified that are not currently present in Alberta but are significant problems in neighbouring jurisdictions. This list, which is not an exhaustive review of potential invaders, includes salt-cedar, yellow star-thistle, garlic mustard, common crupina, exotic deer species, swine (wild boar), Asian longhorn beetle, brown longhorn beetle, larger European pine shoot beetle, Asian gypsy moth, whirling disease, spiny water flea, Eurasian water-milfoil, Lyme disease, parasites from exotic cervids, chronic wasting disease, bronze leaf, European larch canker, and sudden oak death. The mountain pine beetle was identified as a 
native species currently on the edge of its range that could become an invasive alien if it undergoes a major range expansion into Alberta.

There are significant gaps in our knowledge of invasive species and their impacts in Alberta. Information on their economic and environmental impacts is too fragmentary to permit an assessment of total costs, but extrapolation from estimates in the US suggests a total of \$1 billion per year may be realistic over all areas of the provincial economy. The distribution, abundance, and effects of invasive plants in rangeland are not known quantitatively. The ecological impacts of introduced insects are little known, and there is a lack of sampling to detect possible invaders, particularly invertebrates, in aquatic systems. The potential impacts of invasive species on carbon sequestration and nutrient cycling also require study.

Alberta has to date escaped some of the more serious impacts of invasive species elsewhere in North America, due to a combination of geographic barriers, extreme climate, remoteness from sources of introduction, and some effective early detection and eradication programs.

Increasing international trade, environmental disturbance, climate change, and the natural dispersal of species from elsewhere in North America, however, will continue to increase the impacts and risks of invasive species in the province. 


\section{INTRODUCTION}

An invasive alien species is defined under the 1992 Convention on Biological Diversity (the "Rio Convention") as

"a species, subspecies or lower taxon, introduced outside its natural past or present distribution ... whose introduction and/or spread threaten biological diversity".

Introduction, in turn, is defined as

"the movement by human agency, indirect or direct, of an alien species outside of its natural range (past or present). This movement can be either within a country or between countries or areas beyond national jurisdiction". (United Nations Environment Program 2002).

This definition, as would be expected given its source, focuses on the impacts of invasive alien species on biodiversity. In addition, invasive alien species can have far-reaching impacts on agricultural and forest production, water resources, ecosystem processes, economic activity, and human health. These impacts are recognized in the definition adopted under US Executive Order 13112:

" 'Invasive species' means an alien species whose introduction does or is likely to cause economic or environmental harm or harm to human health.' (Clinton 1999).

Worldwide, invasive alien species are generally considered to be the second greatest threat to biodiversity after habitat destruction (Wilson 1992). This was confirmed in an analysis of documented threats facing listed threatened or endangered species in the USA (Wilcove et al. 1998) and for aquatic species in the USA by Richter et al. (1997).

Under Article $8(\mathrm{~h})$ of the Convention, the parties, which include Canada, committed themselves to "prevent the introduction of, control or eradicate those alien species which threaten ecosystems, habitats or species".

Examples of invasive alien species include the American grey squirrel, which has been introduced into Europe and is displacing native red squirrels; the Australian paperbark or melaleuca tree, which is invading and transforming the landscape and hydrology of the Florida Everglades; the West Nile virus, which has moved rapidly across North America over the last few years causing widespread disease in birds, mammals, and humans; and the European green $\mathrm{crab}$, which is though to have contributed to the collapse of the softshell clam industry in Maine during the 1950s. Not all introduced species become invasive aliens. As a very rough guide, Williamson's "Tens Rule" suggests that one in ten alien species introduced into a new region will become established as free-living populations, and one in ten of those species that become established will increase and spread to a level at which they can be considered invasive

(Williamson and Brown 1986; Williamson and Fitter 1996). Thus about 1\% of introduced species may be expected to become invasive. This is of course a rule of thumb, subject to wide variation in particular cases. 
The costs and impacts of invasive species have been reviewed extensively in the United States (e.g. U.S. Congress Office of Technology Assessment 1993; Westbrooks 1998; Cox 1999; Pimentel et al. 2000) and the issue became prominent enough to result in the issuing of an Executive Order by President Clinton in 1999. This Order established a National Invasive Species Council and required federal departments and agencies to work together to prevent the introduction of invasive species, detect, monitor, and control their populations, restore affected ecosystems, conduct research, and promote public education. A further requirement of the Executive Order was to develop a National Invasive Species Management Plan (National Invasive Species Council 2001), which is currently being implemented.

In Canada a national invasive species strategy is currently being developed by Environment Canada in collaboration with the provinces. Although considerable documentation (e.g. Nantel et al. 2002) is available for invasive species issues in some geographic areas of Canada, such as the Great Lakes, and for some taxonomic groups of invaders, such as noxious weeds, there has been no overview of invasive species impacts in Alberta. This report was prepared to provide an overview of the costs and impacts of invasive species in Alberta, particularly as they affect the resource management interests of Alberta Sustainable Resource Development. It is hoped that it will be useful in guiding the development of ASRD's policy and programs on invasive species for the province, in concert with other affected departments and levels of government.

The review focuses on invasive species affecting forestry, provincial grazing land, aquatic and wetland environments, and natural ecosystems in Alberta. It should be noted that although the review takes a fairly broad scope, specific aspects are not covered. Impacts of introduced agricultural pests are not covered, except for those affecting grazing land. Introduced species that only affect urban or landscape plantings of species not native to Alberta (such as ash, Fraxinus spp., and elm, Ulmus spp.) represent significant actual and potential economic impacts, but are also not covered. Household or stored product pests are not covered. Some native North American species that did not historically occur in Alberta (such as Manitoba maple or annual ragweed) are expanding their range into Alberta, or have been introduced here by human activities, and may sometimes be considered invasives. However the primary focus of the review is on species introduced from outside North America that affect Alberta Sustainable Resource Development's natural resource management interests.

It was not considered practical to cover all taxonomic groups that could potentially include invasive species in Alberta, given the lack of faunistic and floristic knowledge in many less studied groups such as nematodes, algae, and protists. As agreed in the project proposal, the review covers the following taxonomic categories:

\begin{tabular}{ll}
\multicolumn{1}{c}{ Category } & \multicolumn{1}{c}{ Proposed coverage } \\
Terrestrial plants & Vascular plants (flowering plants, ferns, and fern allies) \\
Terrestrial vertebrates & Full coverage (mammals, birds, reptiles, and amphibians) \\
Terrestrial invertebrates & Coleoptera, Lepidoptera, Hymenoptera, Diptera, Hemiptera, \\
& Homoptera, spiders, phytophagous mites, molluscs, annelids \\
Aquatic organisms & $\begin{array}{l}\text { Fish, Crustaceans, vascular plants, insects, molluscs, } \\
\text { protozoan parasites of fish }\end{array}$ \\
Plant and wildlife diseases & $\begin{array}{l}\text { Bacterial, fungal, and viral diseases affecting vertebrates, } \\
\text { forest trees, and native rangeland plant species }\end{array}$
\end{tabular}


Because of the extent and diversity of invasive plant problems in Alberta, it was also agreed to separate the vascular plant section into non-agronomic species ("weeds" in a broad sense) and escaped agronomics.

\section{METHODS AND DATA SOURCES}

\subsection{Compilation of species lists}

A literature search for information on invasive species relevant to Canada was conducted using the keywords "adventive", "alien", "exotic", "invader", "invading", "invasibility", "invasion", "invasive", "invasiveness", "non-indigenous", or "non-native", co-occurring with "Alberta", "Canada" or "Canadian". An Internet search was also conducted for relevant websites and online databases, and relevant experts were interviewed. Information was gathered from the available literature sources and databases on the distribution, abundance, habitat, economic and environmental impact of the listed species. Noxious weed survey data compiled by the Lands and Forests Division, ASRD, during the period 1999-2003 was provided by ASRD staff (Mike Undershultz and Marian Jones) and imported into a geographic information system (Maplnfo) to provide data on the distribution of introduced plants in the Green Zone.

As an initial step towards the identification of invasive species of concern in Alberta, listings were compiled of all known non-native species established in Alberta in each of the taxonomic groups to be covered by the review. For some groups, such as the vascular plants (Kartesz 1999) and beetles (Bousquet 1991), comprehensive databases were available that allowed reasonably full lists of non-native species in Alberta to be compiled. In other groups, no such systematic source is available and the coverage in many of these is certainly incomplete.

An unpublished invasive species database compiled by the World Wildlife Fund - Canada as part of their Nature Audit Program was provided courtesy of Lindsay Roger, Senior Manager, Wildlife Conservation and Outreach, WWF Canada.

\subsection{Selection of major invasive species in each category}

The initial objective was to identify the five most important invasive alien species in Alberta in each taxonomic category. This objective had to be modified for some categories where there was either an abundance or a lack of identified invasive alien species in the province. The major invasive species in each category were identified by project team members on the basis of the available information on their distribution, abundance, and economic and environmental impacts in Alberta. For each of the non-native species identified in the initial listing, available information on their distribution, abundance, and economic and environmental impacts in Alberta or elsewhere was assembled from sources identified during the literature survey and Internet searches, and entered into a spreadsheet along with references to literature and Internet sources. Little quantitative data was found on either economic or environmental impacts, so the selection of the major invasive species in each taxonomic category was based primarily on distribution and abundance, supplemented where possible by impact information from any available sources. In the case of some taxonomic groups, only a few invasive species were identified in Alberta, so selection of the most important species was not difficult. In other groups, particularly the vascular plants, a large number of invasive species are known and it was difficult to objectively rank the top invaders. Inventory data from weed surveys by ASRD 
staff, provided by Mike Undershultz and Marian Jones, were compiled to obtain some indication of the frequency and distribution of invasive plants in the Green Zone. These were used in conjunction with experience of these species in the White Zone to select the major invasive species for more detailed discussion.

Information on impacts of invasive species on species at risk was obtained from the Environment Canada Species at Risk website (Environment Canada 2003) and from the Alberta Wildlife Status reports prepared for some species.

\subsection{Introduction pathways}

Import statistics for Alberta over the period 1998 - 2002 were obtained from Industry Canada's Trade Data Online site (Industry Canada 2003), covering a number of product categories considered to be relevant to invasive species introduction risks. Statistics were collected for various plant products, live animals, aquatic species, and wood-related products. As trade in non-biological items also carries invasive species risks, through the possible carrying of invasive species in vehicles, containers, and crating and packaging materials, data were also collected for total imports into Alberta from outside Canada over the same period. Statistics on interprovincial trade volumes for the period 1997 - 1999 (goods only, excluding services) were obtained from BC Statistics (2000). Statistics on quarantine interceptions by the Canadian Food Inspection Agency were obtained from the Canadian Food Inspection Agency (2002a).

Climatic matching with Alberta was investigated using the Climex 1.1 package (Sutherst et al. 1999). The climate match index produced by Climex is based on comparing monthly maximum and minimum temperatures, rainfall amount, and rainfall pattern. It ranges from 0 for no match to $100 \%$ for perfectly matched climates. The "Match Climates" option was run for five Alberta locations representing a range of climatic conditions in the province (Fort McMurray, Grande Prairie, Edmonton, Calgary, and Medicine Hat) against Climex's world climate database. A composite match index for Alberta was produced by selecting the highest match value for any of the five Alberta locations at each of the over 2,000 world locations in the Climex database.

\subsection{Identification of threats}

Species not currently established in Alberta were identified as potential invasive threats if they occurred in neighbouring areas such as British Columbia, the prairie provinces of Canada, or the northern United States, and showed evidence of significant invasiveness or impact in those areas. Most such species were introductions from outside to North America, but the mountain pine beetle was identified as a native North American species with potential to become invasive in Alberta through range expansion.

For the vascular plants a search was conducted in the Synthesis of the North American Flora database (Kartesz 1999) for species introduced to North America, not present in Alberta, present in any of Alaska, Yukon, Mackenzie, Keewatin, BC, SK, MB, WA, ID, MT, or ND, and listed as a state or federal-level noxious weed in the United States. A few species were added to this list that are known invasives although not federally or state listed as noxious.

It is important to note that this assessment does not represent a comprehensive review of potential invasive species threats in Alberta. The species identified are all considered potential problem invaders in Alberta, but other species not listed may represent equally high risks. A 
full review to identify and categorize all potential invasive species problems for Alberta was beyond the scope of this study.

\section{LISTING OF INVASIVE SPECIES CURRENTLY PRESENT IN ALBERTA}

The full lists of invasive species identified in Alberta by taxonomic group are presented in Appendix 2. It was difficult to apply a uniform criterion of what constituted invasiveness. For the vascular plants, only those introduced species that are established in Alberta and are known to show weedy or invasive behaviour to some extent in the province or elsewhere are included. For the insects there is usually insufficient information to determine their ecological impacts. Thus the species listed in this category are introduced species known to be established in the province, with the exception of strictly agricultural, urban or domestic species.

\subsection{Terrestrial plants}

According to the Synthesis of the North American Flora (Kartesz 1999) a total of 2,198 unique taxa (including 1,932 species) of vascular plants occur in Alberta. Of these, 301 taxa (296 species) are introduced from outside North America. An additional 9 taxa not listed in the Synthesis were identified from other sources as being exotic in Alberta; these include some species native elsewhere in North America, and species that contain both native and exotic biotypes. Fifty species from this list have been reported at least at times to be weedy or invasive in Alberta (Table 3). Thus, approximately $14 \%$ of the Alberta flora consists of exotics and around $2 \%$ consists of invasive or weedy exotic species. Around $16 \%$ of exotic vascular plant species established in Alberta are thus invasive to some degree, in approximate agreement with the tens rule. It is not possible with the available data to estimate what percentage of species introduced into the province have become established, as there is no record of introductions that have failed to become established.

Invasive plant problems occur widely in Alberta, with significant impacts from a relatively wide range of species, and are more thoroughly documented than any other group of invasive species in the province. Because of the extent and diversity of invasive plant problems in Alberta, they have been divided into two categories, non-agronomics and escaped agronomics. Plants in the non-agronomic category are typically either accidental introductions or escaped ornamentals, and generally have no recognized agricultural benefits. Non-agronomic species recognized as "weeds" are regulated under the Alberta Weed Act primarily because of their actual or potential impacts to agricultural production, although environmental impact was a factor in the listing of purple loosestrife, Lythrum salicaria, as a restricted weed. The escaped agronomics are primarily grasses and legumes that were deliberately introduced as pasture or forage species, and are often still valued in agricultural environments. In natural ecosystems, however, they may have significant impacts on biodiversity and ecosystem function.

The distribution of some invasive plant species found during noxious weed surveys conducted in the Green Zone by ASRD staff is shown in Figure 1. It should be noted that these are not systematic surveys, and not all areas of the Green Zone were surveyed. Species other than those on the provincial weed list (such as escaped agronomics) were not generally reported. These maps give a general indication of the areas of the province in which these invasive plants can be found, but do not necessarily mean that a species is absent from areas where no records are shown. The frequency of occurrence of these species in the surveys is shown in Table 1. 


\subsection{Terrestrial invertebrates}

Most introduced terrestrial invertebrate records in Alberta are for insects, of which 146 species were found (Table 4). Species known to occur only as agricultural, stored product or domestic pests were not included on this list. For the vast majority of these species, however, only records documenting their occurrence in Alberta and some basic biological data are known, while their impact on native species or ecosystems has been largely unstudied. Four introduced terrestrial molluscs (Table 5) and four introduced earthworms (Table 6) are known in Alberta.

\subsection{Terrestrial vertebrates}

Fourteen terrestrial vertebrate species were considered to be invasive to some extent in Alberta, including seven mammals and seven bird species. No records of any invasive reptile or amphibian species were found (Table 7).

\subsection{Aquatic organisms}

Eight introduced fish species are established in Alberta water bodies (Table 8). There is very little information on introduced aquatic invertebrates in Alberta. A crayfish, Orconectes virilis, appears to have been moved between drainage basins within Alberta, and a European snail, Radix auricularia, has been recorded from Banff.

\subsection{Plant and wildlife diseases}

Very little information is available on exotic plant diseases affecting forests, rangelands or natural ecosystems in Alberta (Table 9). The geographic origin of plant diseases is often much less easy to determine than that of plants or insects. Only three species were identified conclusively as belonging to this category, although one has had a major impact on pinedominated ecosystems in Alberta. Six exotic diseases affecting terrestrial wildlife were found (Table 10).

\section{STATUS OF MAJOR INVASIVE SPECIES IN ALBERTA BY CATEGORY}

The species listed below were identified by the project team as the major invasive species currently present in Alberta in each of the specified categories. In some cases fewer than five significant invasive species could be identified in a given category. Among the terrestrial plants, selection of a "top ten" is inevitably arbitrary to some extent. A number of other species are widespread, such as perennial sow-thistle, dandelion, yellow toadflax, and leafy spurge. Others, such as wild caraway, purple loosestrife, spotted knapweed, and field scabious are limited to smaller areas, either because of active control programs or more recent arrival, but show potential for significant impact.

Terrestrial plants non-agronomic category

Terrestrial plants escaped agronomics
Canada thistle, Cirsium arvense (L.) Scop.

Common tansy, Tanacetum vulgare $\mathrm{L}$.

Scentless chamomile, Tripleurospermum perforatum (Mérat) M. Lainz

Tall buttercup, Ranunculus acris L.

Oxeye daisy, Leucanthemum vulgare Lam.

Smooth brome, Bromus inermis Leyss.

Kentucky bluegrass, Poa pratensis L.

Timothy, Phleum pratense L. 


$\begin{array}{ll} & \text { Crested wheatgrass, Agropyron cristatum (L.) Gaertn. } \\ & \text { White clover, Trifolium repens L. } \\ \text { Terrestrial vertebrates } & \text { Feral cats, Felis catus L. } \\ & \text { House sparrow, Passer domesticus L. } \\ & \text { European starling, Sturnus vulgaris L. } \\ & \text { Feral dogs, Canis familiaris L. } \\ & \text { Norway and Black or Roof Rat, Rattus norvegicus (Berkkenhaut) and } \\ & \text { Rattus rattus L. } \\ \text { Terrestrial } & \text { Mountain pine beetle, Dendroctonus ponderosae (Hopkins) } \\ \text { invertebrates } & \text { Seven-spotted lady beetle, Coccinella septempunctata L. } \\ \text { Aquatic organisms } & \text { Brown trout, Salmo trutta L. } \\ & \text { Brook trout, Salvelinus fontinalis (Mitchill) } \\ & \text { Cutthroat trout (Yellowstone), Oncorhynchus clarki bouvieri (Bendire) } \\ \text { Plant and wildlife } & \text { Rainbow Trout, Oncorhynchus mykiss (Walbaum) } \\ \text { diseases } & \text { White pine blister rust, Cronartium ribicola J.C. Fisch. } \\ & \text { West Nile Virus } \\ & \text { Brucellosis, Brucella abortus (Schmidt) } \\ & \text { Bovine tuberculosis, Mycobacterium bovis Karlson and Lessel }\end{array}$

The following sections provide some details on these major invaders.

\subsection{Terrestrial plants - non-agronomics}

\subsubsection{Canada thistle}

\section{STATUS AND DISTRIBUTION}

Canada thistle is widespread and often abundant throughout the province. In the Land and Forest Division surveys from 1999 to 2002 it was especially common in SRD corporate areas SW2,3,4, NE1, and NW1 (Figure 1).

\section{HABITAT}

Canada thistle occurs along roads and pipelines, on well sites, grazing leases, cut blocks, and recreation areas in the forested areas of Alberta. It frequently occurs along lakeshores and creek banks. It is also a common weed of pastures, cultivated land, wastelands, and urban areas throughout the province, although it is less common in dryer areas and in the south.

\section{ECONOMIC IMPACT}

Canada thistle is one of the major agricultural weeds of the prairies, causing significant yield losses and management problems in a wide variety of crops. It is also common and often abundant in pastures, particularly on moister soils. Recent studies have show that it reduces forage yield of pastures by up to $2 \mathrm{~kg}$ for every $\mathrm{kg}$ of thistle biomass (C. Grekul and E. Bork, University of Alberta, unpublished).

\section{ECOLOGICAL IMPACT}

Canada thistle is capable of crowding out and replacing native grasses and forbs, decreasing the species diversity of an area, and changing the structure and composition of some habitats 
(Hutchison 1992). It was rated as a moderately invasive but widespread problem in natural areas (White et al. 1993).

\subsubsection{Common tansy}

\section{STATUS AND DISTRIBUTION}

Common tansy was originally introduced as an ornamental, culinary, and medicinal herb, but is now rarely used for these purposes. It has escaped from cultivation and is established widely across Alberta, primarily in central and northern areas. In a 1993 survey in the agricultural areas of the province, based on telephone interviews with agriculture fieldmen, it was found mainly in central and east-central Alberta (White 1997). In the Land and Forest Division surveys from 1999 to 2002 it was especially common in SRD corporate areas SW4, NE1, NE2, and NW1 (Figure 1). Interestingly, in the 1993 survey no tansy was reported in the MD of Opportunity No. 17, whereas in the LFD surveys it was found frequently in the southern part of the MD around Calling Lake. This suggests that tansy is increasing its range within the province.

\section{HABITAT}

In the Green Zone tansy is found along roads and pipelines, on well sites, gravel pits, cut blocks, grazing areas, railways, natural areas, and recreation areas. In the rest of the province tansy is common along roadsides and fencelines, in pastures, waste areas, riparian zones, and urban areas.

\section{ECONOMIC IMPACT}

Tansy competes with desirable forage species and reduces the productivity of pastures (McClay unpublished; White 1997). It contains aromatic essential oils that give it a strong flavour and make it unpalatable to livestock. One of these essential oils, a-thujone, is highly toxic, causing convulsions, seizures, and abortions. Anecdotal information suggests that tansy poisoning has caused abortions in domestic cattle and deer herds. Tansy biotypes vary considerably in their chemical makeup. In a survey in Alberta up to $50 \%$ of plants in some areas tested positive for athujone (McClay et al. 2002a). Tansy is a major problem on the St. Paul's and Rannach Provincial Grazing Reserves, (G. Ehlert, pers. comm.).

\section{ECOLOGICAL IMPACT}

Tansy can form dense monospecific stands in pastures and riparian areas, excluding native vegetation. Its impact on grazing wildlife is likely to be similar to that on domestic cattle. In British Columbia weed control staff with the Ministry of Forests believe common tansy could become a very serious problem on gravely soils in high precipitation areas such as highway shoulders, gravel pits, river estuaries and other riparian zones both in the interior and at the coast (D. Brooke, pers. comm.).

\subsubsection{Scentless chamomile}

\section{STATUS AND DISTRIBUTION}

Scentless chamomile is widespread and appears to be increasing in northern Alberta, and has also been found in the Northwest Territories (J. Woosaree, ARC, pers. comm.). In the LFD surveys it was the most frequently reported noxious weed, and was commonly found in all northern areas surveyed. It was less frequent in the Rocky Mountain Forest Reserve. In the 
White Zone, scentless chamomile is common in central Alberta and the Peace River district, and less so in the south. Some municipalities have raised scentless chamomile to "restricted" status under the Weed Act, requiring it to be destroyed whenever found. It is suspected that it is frequently moved with contaminated soil, gravel, vehicles, and machinery. Biological control agents have been released and established against scentless chamomile (McClay et al. 2002b).

\section{HABITAT}

Scentless chamomile was found around campsites, access roads, cut blocks, gravel pits, grazed areas, pipelines, well sites, and storage areas. In the agricultural areas of Alberta and Saskatchewan, scentless chamomile is usually found in disturbed or cultivated land, around field edges and slough margins, along creek banks, in wasteland, construction sites, and in urban and industrial areas (Bowes et al. 1994).

\section{ECONOMIC IMPACT}

Scentless chamomile is a strong competitor with cultivated crops, particularly with forages in the early stages of establishment. Infested fields in central Alberta can be completely white with scentless chamomile blooms in July. Gravel pits infested with scentless chamomile may have to be shut down to prevent movement of seed to new sites in contaminated gravel. It is not palatable to livestock and has low nutrient value.

\section{ECOLOGICAL IMPACT}

Scentless chamomile spreads and increases very rapidly, once established, due to its profuse seed production, up to 1.8 million seeds $\mathrm{m}^{-2}$ (Woo et al. 1991). It can become dominant in periodically disturbed or flooded areas such as slough margins and temporary creeks. It can form very dense stands when first established, that shade out and outcompete most other vegetation. These stands tend to fade out after a few years as they are outcompeted by perennial species, but they leave a large seed bank in the soil that will reinfest if the ground cover is disturbed again at a later date. Scentless chamomile at present occurs mainly in disturbed areas where the plant community includes many other introduced species. As it spreads into more northern areas of Alberta it is likely to come in contact with more native plant communities, where it has the potential to disrupt successional patterns in areas that have been disturbed by oil, gas, or forestry operations.

\subsection{4. $\quad$ Tall buttercup}

\section{STATUS AND DISTRIBUTION}

Tall buttercup appears to be increasing in abundance in Alberta. In the SRD surveys it was particularly abundant in all areas of the Southwest region, as well as in area NE1 around the Calling Lake area.

\section{HABITAT}

Tali buttercup is found in pastures, grazing areas, recreation areas, natural vegetation, oil and gas sites, and along roads and seismic lines. It prefers relatively moist conditions. It seems less dependent on disturbance and better able to establish in a closed vegetative community than some of the other invasive plant species in Alberta. 


\section{ECONOMIC IMPACT}

Tall buttercup contains a bitter, irritating oil, protoanemonin, that is toxic to grazing livestock and other animals (especially cattle). This can cause gastrointestinal irritation, salivation, diarrhea, and abdominal pain, with convulsions in severe cases. Because the fresh foliage of tall buttercup is distasteful, animals tend to avoid it until all better forage is gone, but some individual cattle will develop a preference for buttercups and feed on them even though better forage is available (Kingsbury 1964).

\section{ECOLOGICAL IMPACT}

The ecological impact of tall buttercup has not been studied. Invasion of tall buttercup into areas used for grazing by native ungulates will presumably reduce the quality and quantity of forage available and have a similar impact to that found on cattle.

\subsection{5. $\quad$ Oxeye daisy}

\section{STATUS AND DISTRIBUTION}

Oxeye daisy was found mainly in areas SW3 and SW4, with scattered occurrences in the Northeast region. It was the most frequently encountered weed in the Southern Rockies area (SW1) in the 2002 and 2003 weed surveys. According to Frankton and Mulligan (1987), oxeye daisy was "rare in most of Alberta" in the 1980s. It thus appears to have increased substantially over the last two decades.

\section{HABITAT}

In the PLFD surveys, oxeye daisy occurs in pastures, roads, pipelines, gravel pits, well sites, rail tracks, recreation areas, and parks. Typical habitat includes mainly roadsides, native grasslands, rangeland, pastures, hay fields, abandoned croplands, railway embankments, rocky shores, rock outcrops, forest openings and waste ground but it also is found in cultivated land, gardens and lawns (Clements et al. In press).

\section{ECONOMIC IMPACT}

Oxeye daisy can establish dense stands in pasture, reducing plant species diversity and hay or forage production. In west-central Alberta, heavily infested hay and pastureland may be completely white with $L$. vulgare in July. It is usually avoided by grazing cattle, and can impart an off-flavour to milk of cattle that graze on it. It acts as a host reservoir for gall-forming nematodes (Meloidogyne spp.) which are pests of crops.

\section{ECOLOGICAL IMPACT}

Oxeye daisy is a perennial which reproduces by seed and by rooting along the decumbent portions of the stem and lowest branches. Seeds remain viable when passing through the digestive tracts of horses and cattle, and may be spread in manure. Oxeye daisy competes with native species and reduces plant community diversity. Because of the relatively shallow root system of oxeye daisy in comparison to those of perennial grasses, large populations render areas vulnerable to soil erosion and deplete soil organic matter. In its native range, oxeye daisy is an effective inhibitor of establishment by seedlings of invading species, possibly due to high populations of root nematodes associated with it (van Ruijven et al. 2003). This suggests that it may itself be very competitive as an invader. 


\subsection{Terrestrial plants - escaped agronomics \\ 4.2.1. Smooth brome}

\section{STATUS AND DISTRIBUTION}

Smooth brome is native to Eurasia, however the variety used in the northern Great Plains originated in Siberia (Magness et al. 1971). In North America it occurs from Alaska and all the Canadian provinces and territories south to southern California and New Mexico, northern Oklahoma, and North Carolina (Stubbendieck et al. 1992).

In Alberta smooth brome is a widespread seeded forage species throughout the moister portions of the province. In particular, smooth brome has been used as a forage species throughout much of the moist mixed grass prairie and aspen parkland regions of the province. Smooth brome also occurs as an escaped agronomic throughout much of the green zone, in particular as an invading species within rough fescue grasslands and riparian areas (Smoliak et al. 1981).

\section{HABITAT}

In its native Eurasian range smooth brome grows on roadsides, riverbanks, edges of fields and woods and pastures (Looman 1983). In Alberta it is common in pastures, cultivated land, wastelands, and urban areas throughout the province, although it is less common in dryer areas and in the south. The species is well adapted to the moist mixed grass and aspen parkland natural regions of Alberta where adequate precipitation allows it to maximize production and enhances the species' invasive abilities.

Smooth brome is a perennial cool season grass that reproduces by both seed and vegetative structures (rhizomes) (Looman 1983). It ranges in height from 1.3 to 3.2 feet $(0.4-1.0 \mathrm{~m})$ tall. Blades are flat. The inflorescence is an open panicle from 2.4 to 6.8 inches $(6-17 \mathrm{~cm})$ long bearing 6 to 11-flowered spikelets. Lemmas have short awns $(<2 \mathrm{~mm})$ or are unawned (Stubbendieck et al. 1992). Two principal types of smooth brome are recognized, the northern and southern. The northern type is weakly rhizomatous, with leaves well up on the stem and short glumes. A few northern cultivars are actually bunchgrasses. The southern type is strongly rhizomatous, with leaves near the base of the stem and long glumes. Other notable differences are earlier spring growth of the southern type and more even growth of the northern type through the growing season. Due to cloning, smooth brome is a long-lived species. Plantings have persisted for at least 60 years (Plummer et al. 1968).

\section{ECONOMIC IMPACT}

Economic value of smooth brome as a forage for grazing livestock has been documented in the context of seed and livestock production. In Alberta in 2001 about 10.7 million acres of tame forages were seeded for pasture and hay production with a value of about 1.1 billion dollars (Arvid Aasen AAFRD pers comm.). In the Peace region over 340,000 acres of forage crops for seed production were grown in 2001 (Anon 2003). The proportion of this that was smooth brome is unknown. Estimated value of this production was on the order of $\$ 30$ to $\$ 40$ million. No economic impact studies viewing smooth brome as an invading species were found. 


\section{ECOLOGICAL IMPACT}

Smooth brome is an aggressive invader of prairie dominated by plains rough fescue (Festuca altaica subsp. hallii), displacing native flora (e.g. Grilz and Romo 1995). In particular invasion of rough fescue grassland communities within the aspen parkland and foothills natural regions of Alberta has been identified. Research directed toward reversing this invasion using prescribed burning and chemical control has been conducted within Parks and Natural Areas (Anderson 1994; Masters et al. 2001).

\subsubsection{Kentucky bluegrass}

\section{STATUS AND DISTRIBUTION}

Kentucky bluegrass is widely distributed across North America growing in every state and Canadian province. It is well adapted for growth in cool, humid climates, and is most prevalent in the northern half of the United States and the southern half of Canada. It is not common in the Gulf States nor in desert regions of the Southwest United States nor tundra regions of the far North (Stubbendieck et al. 1992).

In Alberta Kentucky bluegrass is a widespread occasionally seeded forage species throughout the moister portions of the Province. Like, smooth brome Kentucky bluegrass also occurs as an escaped agronomic throughout much of the green zone in particular as an invading species within rough fescue grasslands and riparian areas and occurs in many other community types including aspen forests usually as a minor component.

\section{HABITAT}

Kentucky bluegrass is adapted to a wide range of habitat conditions but favours moist habitats and can withstand temporary flooding. It is found in meadows, open woodlands, prairies, and disturbed sites. It is commonly planted as a lawn grass and a pasture grass in some areas. Kentucky bluegrass is well adapted to most soil types, although it is most common on finetextured soils. Kentucky bluegrass is native to Europe, Eurasia, and possibly North America. Some scientists theorize that Kentucky bluegrass may have migrated across the Bering Land Bridge 12,000 to 20,000 years ago. It was probably introduced to the east coast by early colonial settlers sometime after 1600 and spread westward by settlers. The species is now often considered to be naturalized (Butterfield et al. 1996).

Kentucky bluegrass is an introduced, perennial, short to medium-tall, cool-season, sod-forming grass. The leaves are primarily basally attached and are usually 4 to 12 inches $(10-30 \mathrm{~cm})$ long. Stems are numerous in a tuft and grow 12 to 36 inches $(30-91 \mathrm{~cm})$ high. The inflorescence is an open panicle. Kentucky bluegrass is shallow rooted and is intolerant of drought. Most roots and rhizomes are found within 3 inches $(7.5 \mathrm{~cm})$ of the soil surface. It is a highly palatable and nutritious pasture grass that is highly adapted to grazing and is also extensively used for lawns and turf. It is readily established by seeding. Numerous varieties are in commercial use (Looman 1983).

\section{ECONOMIC IMPACT}

Economic value of Kentucky bluegrass as a forage for grazing livestock has been documented in the context of seed and livestock production. In Alberta in 2001 about 10.7 million acres of tame forages were seeded for pasture and hay production with a value of about 1.1 billion dollars 
(Arvid Aasen AAFRD, pers comm.). In the Peace region over 340,000 acres of forage crops for seed production were grown in 2001 (Anon. 2002) with an estimated value of 30 to 40 million dollars. The proportion of this that was Kentucky bluegrass is unknown, but total acreage of Kentucky bluegrass for certified seed production in Canada declined by around $90 \%$ between 1995 and 2000 (Young 2001). No economic impact studies viewing Kentucky bluegrass as an invading species were found.

\section{ECOLOGICAL IMPACT}

The ecological impact of Kentucky bluegrass results primarily from its ability to aggressively invade native plant communities particularly under heavy grazing thus displacing native flora and often resulting in reduced production and biodiversity. In particular invasion of riparian areas throughout the province as well as invasion of rough fescue grassland communities within the aspen parkland and foothills natural regions of Alberta have been identified. Within riparian areas the shallow roots of Kentucky bluegrass usually result in less stable riparian areas as streambank cohesiveness is reduced. Research directed toward reversing these invasive tendencies using rest, prescribed burning, chemical control and livestock grazing management has been conducted within Parks and Natural Areas (e.g. Launchbaugh and Owensby 1978).

\subsection{3. $\quad$ Timothy}

\section{STATUS AND DISTRIBUTION}

Timothy, Phleum pratense L., is of Eurasian origin but was first cultivated in the United States. It was found growing in New Hampshire in 1711 and was named herd's grass. In 1747, timothy spread from New England to Canada and westward (Smoliak et al. 1981). Timothy is found in all 50 states and throughout Canada except Prince Edward Island and Labrador. Timothy is widely cultivated in the northeastern states south to the Cotton Belt and west to the 100th meridian, in humid regions of Puget Sound, and in mountainous regions.

In Alberta timothy is a commonly seeded forage species throughout the moister portions of the Province. In addition timothy has been frequently used for reclamation after fires and other disturbances, although this use s now being discouraged. As a result like smooth brome and Kentucky bluegrass timothy also occurs as an escaped agronomic throughout much of the green zone in particular as an invading species within rough fescue grasslands and riparian areas and meadow types and occurs in many other community types as well including aspen and coniferous forests usually as a minor component.

\section{HABITAT}

In its native range timothy grows on roadsides, riverbanks, edges of fields and woods and pastures. It is also a common weed in some pastures, cultivated land, wastelands, and urban areas throughout the Province. Timothy is less common in dryer areas and in the southeast unless in moist or irrigated areas. The species is well adapted to the moist mixed grass, aspen parkland boreal, foothill and mountain natural regions of Alberta where adequate precipitation allows it to maximize production and enhances the species invasive abilities.

Timothy is an introduced, cool-season, perennial bunchgrass that grows from 20 to 40 inches $(51-102 \mathrm{~cm})$ tall. Culms emerge from a swollen or bulblike base and form large clumps. The flowering heads of timothy are cylindrical and spikelike, and about 6 inches $(15 \mathrm{~cm})$ long. The 
one-flowered spikelet produces seeds that are small and enclosed in awned, urn-shaped husks. Leaves of timothy are flat and 3 to 13 inches $(7.6-33 \mathrm{~cm})$ long. Timothy is generally short-lived ( 4 to 5 years) but can live up to 6 or 7 years. Timothy has a moderately shallow and fibrous root system; roots can extend to 48 inches $(120 \mathrm{~cm})$ in depth. Timothy is non-rhizomatous. Timothy plants contain corms at their base which are annual, forming in early summer and dying the next year when the seed matures (Looman 1983; Stubbendieck et al. 1992).

\section{ECONOMIC IMPACT}

Economic value of timothy as a forage for grazing livestock has been documented in the context of seed and livestock production. Pedigreed seed production of timothy in Canada in 2000 was almost 43,000 acres (Young 2001). No economic impact studies viewing timothy as an invading species were found.

\section{ECOLOGICAL IMPACT}

Timothy is an exotic of great concern to wildland managers because it establishes quickly, spreads vigorously, and usually escapes early detection. Timothy had the highest ability of 34 exotics tested to invade closed vegetation areas (Weaver et al. 1990). Numbers and frequency of timothy plants increases from undisturbed sites to regularly disturbed sites. More resources are available at the latter sites because competition is greatly reduced. Alberta SRD Range staff have been finding Timothy invading in the foothills from grazed grasslands due to early seed production and dispersal. As a result timothy is expanding onto dry, south facing slopes (not grazed), out-competing native vegetation (Willoughby et al. 2003). Hence Timothy is of great concern because it often dominates the area it occupies thus displacing native flora. Timothy also occurs on extremely cold sites that seldom burn (Wasser 1982). This ability to withstand cold sites makes timothy a potential invasive threat to boreal forest types. It has been observed expanding into cut blocks from adjacent roadside vegetation (C. Lane, ASRD, pers. comm.).

\subsection{4. $\quad$ Crested wheatgrass}

\section{STATUS AND DISTRIBUTION}

Crested wheatgrass, Agropyron cristatum L., is an introduced species, originally from Russian and Siberian steppe habitats. It has been planted from Alaska south to California, throughout western Canada, east in the United States to Ohio, and south to Texas. It was first successfully established in the United States between 1907 and 1913 (Dillman 1946). Crested wheatgrass varieties from Siberia were first introduced to Canada in 1915 (Looman 1983). Crested wheatgrass and desert wheatgrass were considered distinct species upon their first introduction to the United States in 1906, but since, the two species have often been referred to and treated as one. Crested and desert wheatgrass became prevalent in the United States and the Great Plains of Canada in the 1930s when they were used to seed abandoned cropland. Crested wheatgrass is most common in the northern Great Plains, especially North and South Dakota, eastern Montana and Wyoming, and in southern Saskatchewan and southeastern Alberta. The grass is used throughout the arid and semi-arid regions of the West including the high desert regions of Eastern Oregon, Eastern Washington, Idaho, Utah and Nevada. Crested and desert wheatgrass seedings have been established on 10 million acres ( 3.2 million ha) and, by some accounts, as much as 26 million acres (10.4 ha) in North America. 
In Alberta crested wheatgrass is primarily found in the southeastern portions of the province occurring as seedings many dating from the drought years in the 1930's. As such the species has replaced many native dry mixed grass prairie plant communities. In addition crested wheatgrass has been used as a part of species mixes for renovation of well sites, pipeline right of ways and roadsides. The species is also often planted within the moist mixed grass prairie and drier portions of the aspen parkland as a part of seeding mixes designed to provide forage for domestic livestock.

\section{HABITAT}

Crested wheatgrass is tolerant of very cold and very dry conditions, typical of both its native habitat in Siberia and Russia and some areas of the northern Great Plains (Shiflet 1994). It grows best on medium-textured soils, from sandy loams to clay loams. Crested wheatgrass does not grow well in loose sandy soils, heavy clays, or saline soils. Crusted soils also reduce crested wheatgrass seedling emergence.

Crested wheatgrass is a cool-season, medium-height, exotic perennial bunchgrass. The plant is drought- and cold-resistant and long-lived, enabling it to establish in recognizable monocultures. Crested wheatgrass culms are 10 to 40 inches $(25-100 \mathrm{~cm})$ tall and widely spaced. The deep, finely branched fibrous roots of crested wheatgrass penetrate to a maximum depth of 8 feet $(2.4 \mathrm{~m})$, with most roots extending to a depth of 3.3 feet $(1 \mathrm{~m})$. Crested wheatgrass is common in the Northern Great Plains and in Canada, while desert wheatgrass is more common throughout the western United States. Crested wheatgrass remains productive for more than 30 years. Stand mortality is virtually unknown, except in cases of extreme drought during critical phenological stages (Hardy BBT Ltd. 1989).

\section{ECONOMIC IMPACT}

No economic impact studies on crested wheatgrass as an invading species were found.

\section{ECOLOGICAL IMPACT}

The ecological impact of crested wheatgrass results primarily from its potential to invade native plant communities thus displacing native flora. Although crested wheatgrass does not invade sites as aggressively as rhizomatous species such as smooth brome or Kentucky bluegrass, it does have the ability to exclude other species establishment particularly native species. As a result native plant communities may be difficult if not impossible to re-establish (Wilson 1989). Research directed toward reducing invasion and enhancing native species using prescribed burning, chemical control and livestock grazing management has been conducted within Parks and Natural Areas.

Additional research has suggested that crested wheatgrass seedings have apparently lower carbon sequestering potential than native prairie (Christian and Wilson 1999) however additional research challenges this conclusion (Schuman et al. 2002).

A positive note to the interspersion of crested wheatgrass within native prairie however concerns the species early spring growth and development typically earlier than native prairie thus relieving grazing pressure from associated native prairie early in the growing season (Urness 1983). 


\subsubsection{White clover}

\section{STATUS AND DISTRIBUTION}

White clover, Trifolium repens L., has a circumboreal distribution (Hardy BBT Ltd. 1989). It was introduced to North America from Europe and was well established by 1750 . The species has since naturalized throughout Canada and the United States. There are three types of white clover in Alberta. They are ladino, or large white clover; white Dutch, or intermediate or common white clover; and the wild type, also known as low growing or small white clover. The ladino type grows two to four times taller than white Dutch and is, therefore, much higher yielding. It is less winter hardy, less resistant to very low clipping and less likely to flower well, especially in cloudy, moist climates. All three types are closely related and cross pollinate. In mixtures, grasses are stimulated by the nitrogen released, thereby improving yield and protein content of the forages.

In Alberta Dutch white clover is an occasionally seeded forage species throughout the moister portions of the Province. In addition, white clover has been frequently used for reclamation after fires and other disturbances. As a result, like smooth brome, Kentucky bluegrass, and timothy, white clover also occurs as an escaped agronomic throughout much of the green zone.

\section{HABITAT}

In its native range white clover grows on roadsides, riverbanks, edges of fields and woods and pastures. It is also a common weed in some pastures, cultivated land, wastelands, and urban areas throughout the Province. White clover is less common in dryer areas and in the southeast unless in moist or irrigated areas where ladino white clover is sometimes seeded. The species is well adapted to the moist mixed grass, aspen parkland boreal, foothill and mountain natural regions of Alberta where adequate precipitation allows it to maximize production and enhances the species invasive abilities.

White clover is a short- to long-lived perennial (Smoliak et al. 1981). It has a shallow tap root which may grow to a depth of at least 3 feet and has very small crowns. It produces aboveground, creeping stems called stolons that root at the nodes, thus permitting individual plants to spread over a considerable area. The plant has no upright stems as the top growth consists of leaf stems or petioles and leaves. There is usually a V-shaped white mark in the middle of each leaflet. The taller growing flowers are predominantly white, as the common name of the species suggests, but are sometimes tinged with pink. The small, yellow seeds have a hard seed coat that permits germination many years after the initial seeding. The hard seed of white clover may pass intact through the digestive tract of grazing animals, thus allowing reseeding and spread of the species.

\section{ECONOMIC IMPACT}

Economic value of Dutch white clover as a forage for grazing livestock has been documented in the context of livestock production. In addition seed production economics for Dutch white 
clover as a forage source have been documented. No economic impact studies viewing Dutch white clover as an invading species were found.

\section{ECOLOGICAL IMPACT}

Dutch white clover is usually classified as a moderately invasive species capable of rapidly colonizing disturbed sites (e.g. forest harvest blocks, road and pipeline right of ways, etc). Because the species is so widespread it is usually viewed as naturalized. White clover thrives in full sunlight and declines as grass cover increases. It will grow in partial shade of aspen and oak woodlands (Wasser 1982). In British Columbia, white clover is one of the first plants to colonize river gravel bars (Garrison et al. 1977).

The seeds are dispersed by wind, water, birds, and grazing animals (Wasser 1982) and are long lived as are the plants themselves. Hull (1973) reported that seeds stored for 25 years in unheated sheds had a germination rate of 73 percent. Harberd (1963) reported that most white clover clones live about 20 years, but some may live to 100 or more years of age.

Because white clover is a nitrogen-fixing plant, it is also usually classified as a facultative seral species. As a result white clover may be enriching disturbed soils for colonization by more aggressive possibly invasive species.

\subsection{Terrestrial vertebrates}

\subsection{1. $\quad$ Feral cats}

\section{STATUS}

There are an estimated 600,000 domestic cats in Alberta (Statistics Canada 2001), many of which are feral cats. In the continental United States the ratio of pet to feral cats is 63 million (Nasser and Mosier 1991) to 30 million (Luoma 1997). Pet cats are in $31 \%$ of Alberta's 1,104,100 households(Statistics Canada 2001). Cats are found in many urban residences and most of the 53,652 farms in Alberta. The number of cats on 152 farms and rural residents in the North Saskatchewan River Basin west of Edmonton ranged from 0 to 20 and averaged 2.6 (Roy, unpublished data). Feral cats are most prevalent in south and central Alberta because of climatic limitations in the north (Luoma 1997).

\section{BIOLOGY}

Cats are associated with human habitation in both urban and rural settings. Feral cats reside primarily in unoccupied buildings in urban settings and in abandoned farm buildings and dumps in rural settings. Survival of wild populations is limited by cold weather.

\section{IMPACT}

Introduced cats pose a serious threat to native birds and other mammals, reptiles and amphibians and also result in significant health care costs from injuries to people, primarily kids from scratches and bites (Pimentel et al. 1999). They also carry the protozoan parasite Toxoplasma gondii that can cause abortion in sheep and humans (Gates 1985). Pimentel et al. (1999) estimated that cats were responsible for more than $\$ 6$ billion damage each year resulting from predation on birds alone in the US. Using their values of 5 birds killed per cat and $\$ 40$ 
CND (\$30 USD) cost per bird, the economic cost to birds alone in Alberta is estimated at \$120 million CND. This estimate does not include small mammals, amphibians and reptiles killed by pet cats (Dunn and Tessaglia 1994). Five illnesses considered to be a health risk to humans from cat defecation are salmonellosis, giardiasis, toxoplasmosis, cryptosporidiosis and roundworms. On the other hand cats provide some benefits to humans from rodent control savings.

\subsection{2. $\quad$ House sparrow}

\section{STATUS}

House sparrows are distributed throughout Alberta. Winter populations are quite high in cities, towns, and farmsteads. Numbers are lower in mountainous and northern regions where human population is low. They are very successful and high populations are being maintained in Alberta.

\section{BIOLOGY}

House sparrows nest in cavities, about buildings, in bird boxes and on tree branches. They produce 3 to 7 eggs annually. Concentrations of birds especially in winter are associated with human habitation or at least with artificial concentrations of food supplies such as bird feeders, grain at feed supply operations or grain storage and distribution to livestock on farms.

\section{IMPACT}

House sparrows damage buildings and consume various crops and livestock feed. They harass native birds and displace native bluebirds, wrens, purple martins, tree swallows and cliff swallows from nesting sites (Long 1981; Godfrey 1986). They are also associated with the spread of 29 human and livestock diseases (Weber 1979).

\subsubsection{European starling}

\section{STATUS}

European starlings (Sturnus vulgaris) were introduced to New York City in 1890 and have since become one of North America's most common species. The starling has flourished and spread rapidly across the North American continent. It was first recorded in Alberta, near Camrose in 1934 and is now found throughout Alberta. It is found in cities, towns and in the country.

\section{BIOLOGY}

The European starling is a cavity nester. It nests in tree cavities, in cavities associated with buildings and cliffs and in bird boxes. Starlings lay 4 or 5 eggs and produce a single brood per year.

\section{IMPACT}

The total monetary damage attributable to invasive starlings reported to the US Wildlife Service from 1990-1997 was \$13.5 million (Bergman et al. 2002). Starlings are known as aggressive competitors that usurp cavities of other hole-nesting species. However, using Christmas Bird Counts and Breeding Bird Surveys, Koenig (2003) found few differences in mean densities of 27 native cavity-nesting species before and after invasion of sites by starlings. Only sapsuckers (Sphyrapicus spp.) exhibited declines potentially attributable to starlings that were not countered by other data. However, it is difficult to predict what would have happened to native bird 
populations in the absence of starlings. Starlings also play a role in the transmission of diseases to humans and wildlife (Weber 1979).

\subsection{4. $\quad$ Feral dogs}

\section{STATUS}

There are an estimated 3.5 million pet dogs in Alberta (Statistics Canada 2001). The number of feral dogs is unknown but likely relatively low in Alberta. Pet dogs are found in most urban and rural residences including farms. Feral dogs are most prevalent in south and central Alberta because of climatic limitations to survival in the north.

\section{BIOLOGY}

Pet dogs are associated with human habitation. Feral dogs however can survive in the wild. In Alberta, cold climate and sparse distribution of human population and farms to the north likely limit dispersal and establishment of feral dog populations.

\section{IMPACT}

Many feral dogs run in packs and kill deer, rabbits and domestic livestock. Losses to livestock from dogs are valued at less than $\$ 100,000$ annually in Alberta (P. Merrill, Alberta Agriculture, pers. comm.). Additional economic costs are associated with injury and sometimes death to people from dog bites. Pimentel et al. (1999) estimated that dog bites were responsible for direct and indirect costs of $\$ 415$ million annually in the US.

The ecological impacts of dogs result from predation on native species ranging from invertebrates, amphibians, reptiles, birds, and both small and large mammals. Addition ecological impacts result from genetic contamination of native coyotes and potentially wolves. There is an increasing number of "coy-dogs" in Alberta in recent years. There is also some potential for dog-wolf crosses in Alberta.

\subsubsection{Norway and Black or Roof Rat}

\section{STATUS}

Alberta Agriculture has maintained a "rat free" status for Alberta since 1937. However rats are removed annually along a $30 \mathrm{~km}$ wide strip in Alberta along the Alberta-Saskatchewan border (Bourne 1998). Additionally, outbreaks occur annually throughout the province. Border removals and outbreak eradication are accomplished primarily by the use of toxicants.

\section{BIOLOGY}

Rats are associated with human habitation or at least with artificial concentrations of food supplies such as dumps or granaries. In Alberta, mountains to the west and cold climate and sparse distribution of human population and farms to the north and northeast act as natural barriers to dispersal and establishment of rat populations.

\section{IMPACT}

Pimentel et al. (1999) estimated that despite improved rat control that rats were responsible for more than $\$ 19$ billion annually in the US. Damage includes consumption and destruction of stored grain and other materials, fires resulting from gnawing electric wiring, contamination of 
foodstuff and acting as vectors of diseases such as salmonellosis and leptospirosis (Richards 1989). The economic impact in Alberta has been kept low due to a rat eradication program conducted by Alberta Agriculture. Using figures developed by Pimentel et al. (1999) and a potential of 20 rats per farm and 1 per other household results in a potential of 2.1 million rats in Alberta. At $\$ 15$ USD or $\$ 20$ CND the potential cost of rats in Alberta is 42.5 million CND. This program cost approximately $\$ 300,000$ per year and saves an estimated potential $\$ 42.2$ million per year. The ecological impact is that rats prey on native invertebrates and vertebrate species such as birds and bird eggs (Amarasekare 1993) and harbour diseases that can affect wildlife.

\subsection{Terrestrial invertebrates}

\subsubsection{Seven-spotted ladybird beetle}

\section{STATUS AND DISTRIBUTION}

Coccinella septempunctata Linnaeus. This species was mass reared and released by the USDA beginning in 1956 in the eastern U.S. for aphid control and into the western U.S. in the 1980s in response to the Russian wheat aphid (Gordon and Vandenberg 1991). It is widely available for purchase for use in controlled environments and field augmentation biological control programs. The insect has become established throughout the province.

\section{HABITAT}

The 7-spotted ladybird beetle is a generalist predator in both larval and adult stages. It moves up into the canopy of plants and actively seeks prey on stems and foliage. This insect overwinters in the adult stage.

\section{ECOLOGICAL IMPACT}

The 7-spotted ladybird beetle is presumed to competitively displace native species of ladybird beetle (Staines et al. 1990; Howarth 1991; Turnock et al. 2003). Within Alberta the widespread release of the 7-spotted ladybird beetle for biological control of pest insects has resulted in a change in abundance of two native species of coccinelline on a provincial scale (Wheatly and Wheatly 2004). The impact of the introduction and increasing use of the Asian Multicoloured Ladybird Beetle, Harmonia axyridis, has not been assessed.

\subsection{Aquatic organisms}

\subsection{1. $\quad$ Brown trout}

\section{STATUS AND DISTRIBUTION}

Native to Europe, Asia, and North Africa, this species has been introduced around the world. It was first introduced to Canada in 1884 and has been successfully introduced across western Alberta beginning in 1924 and including the Athabasca, Bow, North Saskatchewan, Oldman, and Red Deer river drainage systems (Nelson and Paetz 1992).

\section{HABITAT}

Brown trout survive in streams and lakes feeding on insects and fish. Adult brown trout will feed on young brown trout and other small fish. 


\section{ECONOMIC IMPACT}

This species is prized for its sport fishing value.

\section{ECOLOGICAL IMPACT}

While no specific studies have been conducted on the ecological impact of the brown trout in Alberta it is known that this species can persist in habitats unsuitable to native trout species such as warmer waters and silted streams. The brown trout is an aggressive fish that has the potential to competitively displace native species and impact community structure (Simon et al. 2002; Townsend et al. 2004).

\subsection{Plant and wildlife diseases}

\subsubsection{West Nile virus}

\section{STATUS}

West Nile Virus was first isolated in 1937 in Uganda, Africa, but has been found to be endemic to regions from Spain to Asia, Russia and as far south as South Africa and Malaysia. The first confirmed cases in the western hemisphere occurred in New York City, New Jersey and Connecticut in 1999 and 2000. The first confirmed case in Canada was in Ontario in 2001. West Nile was first confirmed in Alberta in July 2003. As of November 14, 2003 there are 180 confirmed positive cases in horses and 232 confirmed positive cases in birds in Alberta. All health regions of Alberta except the Peace Region have had a confirmed case of a bird, horse, mosquito or human infected with West Nile Virus.

\section{BIOLOGY}

The West Nile enzootic cycle includes mosquitoes as vectors and birds as reservoirs, then back to mosquitoes. In the US West Nile has been found in 40 mosquito species and over 70 avian species.

\section{IMPACT}

Healthy adult humans are asymptomatic to West Nile but children and the elderly are at risk. The economic impact is associated with potential for human and livestock infection. Horses are particularly susceptible. The American Crow (Corvus brachyrhynchos) has succumbed in vast numbers. Many other birds are probably at risk or dying. Mortality of birds such as Clark's Nutcracker (Nucifraga columbiana) can in turn affect Whitebark Pine (Pinus albicaulis) and Limber Pine ( $P$. flexilis) regeneration because of their seed dispersal relationship (Hutchins and Lanner 1982). Another ecological consequence is the effect on invertebrates and indirectly bird populations associated with extensive use of pesticides to control mosquito populations to protect human health.

\subsection{2. $\quad \underline{\text { Brucellosis }}$}

STATUS

Canada has been essentially free of the disease in farmed animals since 1985. It is in bison and elk in Wood Buffalo National Park. 


\section{BIOLOGY}

Brucellosis, Brucella abortus, originated in Europe and was brought to North America in cattle from which it spread to bison. Brucellosis was first confirmed in Wood Buffalo National Park in bison in 1956. This bacterium is associated with animals and has many potential wildlife species as reservoirs.

\section{IMPACT}

The spread of brucellosis to livestock would be a severe economic impact to the cattle industry as brucellosis free status would be lost and markets closed. This bacterium also has an impact on bison productivity and survival. The main factor limiting the recovery of the threatened Wood Bison are brucellosis and tuberculosis(Mitchell and Gates 2002).

\subsubsection{Bovine tuberculosis}

\section{STATUS}

In Canada, bovine tuberculosis is nearly eradicated but has been detected in several isolated outbreaks in farmed cattle, bison and elk over the last decade. The disease is not naturally occurring in wildlife populations, however, wild elk within and outside Manitoba's Riding Mountain National Park have been found positive for TB. Most of these animals were found near cattle herds affected by the disease.

\section{BIOLOGY}

Bovine tuberculosis is caused by the bacteria, Mycobacterium bovis. It is not a naturally occurring disease but was brought to North America from Europe in cattle in 1906. It was brought to Canada in plains bison from Montana to Elk Island National Park and Wainwright then in 192528 bison from Wainwright were shipped to Wood Buffalo National Park. This bacterium is spread through airborne transmission and through body fluids.

\section{IMPACT}

BT resides with cattle and bison and elk and affects productivity. BT remains a potential economic threat to the livestock industry and has some effect on wild elk and bison populations.

\subsubsection{White pine blister rust}

\section{STATUS AND DISTRIBUTION}

White pine blister rust (WPBR), caused by Cronartium ribicola, occurs in North America throughout range of whitebark pines. The highest levels of infection in North America occur in the northern Rocky Mountains and Cascades of USA and southern Canada, including Alberta, and in the intermountain ranges of both counties. WPBR was introduced into the western part of the continent in British Columbia in 1910 and has since spread throughout most white pine regions of Alberta, Washington, Idaho, Montana, Wyoming, Oregon, and California.

\section{HOSTS}

Cronartium ribicola has a complex lifecycle in which five types of spores are produced on two plant hosts (aecial and telial hosts) to complete its lifecycle. Aecial hosts of WPBR are members 
of the genus Pinus that have 5 needles per fascicle. The most prominent hosts in North America are Pinus strobus (eastern white pine), P. monticola (western white pine), $P$. lambertiana (sugar pine), $P$. albicaulis (whitebark pine), $P$. flexilis (limber pine) and $P$. strobiformis (southwestern white pine). The disease also affects $P$. aristata (Rocky Mountain bristlecone pine), $P$. balfouriana (foxtail pine) which have 5 needles, as well as Pinus cembroides (piñon pine, 2, 3 or 4 needles per fascicle) and $P$. bungeana (lacebark pine, 3 needles per fascicle). Of the susceptible pine species, only $P$. albicaulis and $P$. flexilis occur in Alberta.

Telial hosts of $C$. ribicola are members of the genus Ribes. Host species include cultivated currants and gooseberries, as well as eleven native species.

\section{ENVIRONMENT}

The disease is often most severe in areas and following years with extended, cool, moist conditions during late summer and early fall (Van Arsdel 1972; Cummings-Carlson et al. 2000) Such conditions facilitate spore production, dispersal and infection in pine needles. In some areas, the moisture that facilitates WPBR is often from dew. This means that areas where cool, moist air may settle are generally considered to be favourable to disease development. Infections of pine are not consistent from year to year, but occur in "wave years," when weather is ideal. Generally, conditions are more favourable for infection close to the ground because needles stay wet longer. Because trees have branches close to the ground when they are young, infections are more likely in young trees (Lehrer 1982; Katovich and Mielke 1993). Infections are also likely to be lethal in young trees because the needles are close to the stem, so girdling is more likely, and girdling close to the ground is usually lethal.

\section{ECONOMIC IMPACT}

Once introduced, WPBR can reduce white pine populations until they are too low for commercial utilization (Canadian Forest Service 2003). The potential for damage to the Canadian softwood industry has been estimated to be $\$ 1.5-4.0$ billion (MacIsaac et al. 2002).

\section{ECOLOGICAL IMPACT}

Whitebark pine stands are critical components of high elevation communities. Whitebark pine is one of the first species to regenerate after fires. Pine stands facilitate survival of other conifer species by acting as "nurse" trees. Whitebark and limber pines have evolved a seed dispersal relationship with Clark's nutcrackers (Nucifraga columbiana) (Hutchins and Lanner 1982), and are an important food source for seed eating birds and small mammals, grizzly bears (Ursus arctos) and black bears (U. americanus) (D. Langor, pers. comm.; Tomback 2003). Pine stands also reduce soil erosion and regulate steam flows by prolonging snowmelt at high altitudes. Fire suppression has already put pressure on pine populations, exacerbating the impact of WPBR. Reduction of whitebark and limber pine stands by WPBR negatively affects $N$. columbiana populations, upon which the pines are dependant for seed dispersal, and so pine populations are further reduced. Thus a negative feedback loop is established, made worse by high mortality rates among young trees due to blister rust. (Maloy 2001; Tomback 2003). 


\section{ECONOMIC/ECOLOGICAL COSTS AND IMPACTS}

\subsection{Terrestrial plants}

The available information both on the occurrence and impacts of invasive plant species in Alberta is heavily weighted towards noxious weeds, with less information on escaped agronomic species. The composition and distribution of the invasive plant flora in Alberta is well documented and the nature of problems caused by invasive plants is widely recognized. These problems include the displacement of native species and reduced quality of grazing resources for livestock and wildlife. ASRD surveys indicate that many invasive weed species are increasing and spreading in the Green Zone. Weeds in rangeland cause an estimated annual economic loss of $\$ 2$ billion in the US (DiTomaso 2000). Rangeland invasive plant problems in Alberta, although present, are not yet as severe as those in British Columbia or Montana and other northwestern US states where millions of hectares are affected by leafy spurge, Dalmatian toadflax, spotted and diffuse knapweed (Westbrooks 1998).

About $68 \%$ of Alberta rangelands are under public ownership and administration. In Alberta SRD manages about 3.4 million ha of grazing land under various forms of dispositions. Thus public grazing land forms a very significant resource for the Alberta livestock industry. Any deterioration in range quality due to invasive plants is thus a significant concern. In some areas, naturalized agronomic species such as Kentucky bluegrass may be displacing native grasses such as rough fescue that offer advantages such as extended late-season grazing (Willoughby and Alexander 2000). Despite this, and in contrast with the extensive surveys and economic information available on weeds of annual cropping systems (e.g. Thomas et al. 1998; Leeson et al. 2002), there is relatively little quantitative information available on the extent of invasive plant infestations in Alberta rangeland or on their economic impact. Public Lands and Forests Division spends approximately $\$ 100,000$ annually on weed control measures in the White Area of the province through cooperative efforts with the municipalities, in addition to approximately $\$ 50,000$ to $\$ 100,000$ annually on Provincial Grazing Reserves. In addition, between $\$ 200,000-\$ 300,000$ is spent annually in the Green Area of the province on noxious and restricted weed control and surveys (K. Sundquist, pers. comm.). The Alberta Association of Agriculture Fieldmen, whose members are responsible for most enforcement of the Weed Act in Alberta, has expressed concern about inadequate weed control on ASRD lands.

The weedy vegetation that forms thick mats of vegetation that choke out forest vegetation is a serious concern with forest managers because on disturbed lands weedy species such as Canada thistle, common tansy, smooth brome, timothy and other grasses, can outcompete native vegetation and can prevent the growth of tree species. The exclusion of tree species results in retreatment costs, delayed reforestation timing and impacts to an areas allowable cut. This problem has been seen in mine reclamation areas, and it is potentially a problem in other disturbed areas such as cut blocks, especially cutblock landings, roads, power line and pipeline right of ways (C. Lane, pers. comm. 2003).

Invasive plants are a factor in the status of four plant species at risk in Alberta. The smallflowered sand-verbena, Tripterocalyx micranthus, is endangered in part due to dune stabilization and habitat invasion by both native species and exotics including Russian thistle, crested wheatgrass, flixweed, red-root pigweed and lamb's-quarters (Smith 2003). The western blue flag, Iris missouriensis, is threatened in part by competition from native and invasive species 
including smooth brome (Gould 1999). However, loss of habitat is the major risk factor for this species in Alberta. Slender mouse-ear-cress, Halimolobos virgata, is also threatened in part by invasion of its habitat by non-native species (COSEWIC 2002). Western spiderwort, Tradescantia occidentalis, is threatened by competition with the invasive alien species leafy spurge at some sites in Manitoba and Saskatchewan. At present leafy spurge does not occur at the only known locality for western spiderwort in Alberta (Smith 2001) but it is a potential threat that should be monitored.

\subsection{Terrestrial vertebrates}

There are only a small number of vertebrate species in Alberta that can be categorized as invasive. Problems with invasive mammals such as wild horses and wild boar have been localized in extent. The Norway rat suppression program has been very cost-effective. Some exotic birds such as European starlings and house sparrow are widespread but their ecological impacts are not well known. Cowbird range expansion poses a threat to songbird biodiversity. Further study is needed to determine whether these species are having an effect on native bird populations in Alberta. Predation by dogs and cats is a threat factor for the endangered piping plover Charadrius melodus circumcinctus. There seems to be a relatively low level of threat from new introductions of vertebrates in Alberta. Wild boar should be watched and eradicated where established.

\subsection{Terrestrial invertebrates}

Many introduced insect species are present in Alberta. Introduced insect species are probably largely associated with urban and disturbed or agricultural habitats, and with introduced plants. This is understandable as most crop species are introduced, as are many tree species used for urban landscaping. Some introduced insect species have a major impact as agricultural and urban landscape pests, such as the cabbage seed pod weevil (Dosdall et al. 2001) and the recently introduced European ash psyllid Psyllopsis discrepans.

The ecological impacts of introduced insect species have been little studied in Alberta. Some may be displacing native species, such as the European 7-spot lady beetle, Coccinella septempunctata, which has become the dominant lady beetle in many areas of Alberta over the last 10-20 years. Evidence from some areas indicates that the European 7-spot may be displacing native lady beetle species (Elliott et al. 1996; Cormier et al. 2000; Turnock et al. 2003).

In some cases introduced insects have been shown to be dispersing into less disturbed habitats e.g. a European ground beetle, Pterostichus melanarius, which is gradually moving from a roadside verge into aspen forest (Niemela and Spence 1999). This species, originally from Europe, is a generalist predator. It is most abundant near urban centres but has dispersed into the Aspen Parkland area around Edmonton and into the prairie region south (Dustin Hartley, pers. comm.). When $P$. melanarius is very abundant the native ground beetles $P$. adstrictus Eschscholtz and $P$. pennsylvanicus LeConte appear to be less abundant than when $P$. melanarius is less abundant or absent (Dustin Hartley, pers. comm.).

Most of the invertebrate species considered pests attacking our native forest and rangeland plants are native. Some introduced species are now under effective biological control, such as the birch leaf miners (Langor et al. 2000). The pine false webworm, Acantholyda erythrocephala (L.) was originally introduced in 1989 (C. Saunders, pers. com.). A population has established 
itself in the Edmonton area. It is uncertain if this insect will constitute a major threat to lodgepole pine. Other species in this genus in Canada are considered to be minor pests (Ives and Wong 1988).

\subsection{Aquatic organisms}

The designation of invasive alien species with respect to aquatic organisms must account for the distinct boundaries formed by watersheds or drainage basins. Therefore, we have designated as alien invasives those species that may be native to one drainage basin in Alberta but have been introduced and become established in other drainage basins within Alberta. For this discussion the province is divided into the Eastern slopes, boreal and parkland lakes and prairie river systems.

\subsubsection{Vertebrates}

There have been numerous releases of non-native and native species of fish throughout Alberta to initiate and support a sport fishing industry. These releases have had a substantial impact on the species assemblages and communities within Alberta's fresh water system (Mayhood 1995).

In the Eastern Slopes, the introduction of Yellowstone cutthroat trout, Oncorhynchus clarki bouvieri, rainbow trout, O. mykiss (Walbaum), lake trout, Salvelinus namaycush (Walbaum), and brown trout, Salmo trutta Linnaeus, has had a significant negative impact on native bull trout, Salvelinus confluentus (Suckley), and west slope cutthroat trout, O. c. lewisi (Richardson). Historically the western slope cutthroat trout was widespread in the Bow River drainage and the bull trout all along the mountains. With the introduction of the Yellowstone strain, California and Athabasca rainbow trout, and European brown trout, the west slope strain has been competitively displaced or hybridization has occurred resulting in very few pure strain populations remaining (Behnke 1992; Nelson and Paetz 1992; Mayhood 1995). Bull trout have been largely replaced by brook trout and lake trout along the mountains (Nelson and Paetz 1992; Mayhood 1995).

The displacement of cutthroat trout by brown trout has potentially had an impact on benthic invertebrate communities. Cutthroat trout typically consume a larger size class of fish than do brown trout and mountain lakes with cutthroat trout have benthic communities similar to those of lakes without fish (Nelson and Paetz 1992). An indirect measure of impact is the increased abundance of mountain whitefish, Prosopium williamsoni (Girard), in the Bow River drainage resulting from the decrease in its primary predator. Mountain whitefish feed on benthic invertebrates such as mayflies and stoneflies. An increase in anthropogenic inputs into the Bow river (sewage, run-off) and change in flow rates due to hydroelectric and irrigation projects, coupled with a reduction in abundance among the filter-feeding guild of invertebrates resulting from an alteration in the species composition of fish, contribute to a negative impact on water quality (M. Sullivan, pers. comm.).

Although not listed by COSEWIC, the status of the bull trout Salvelinus confluentus is considered to be "sensitive" in Alberta (Alberta Environment 2001). This is partly a result of competition from, and interbreeding with, the introduced brown trout (Salmo trutta), rainbow trout 
(Oncorhynchus mykiss), brook trout (Salvelinus fontinalis), and lake trout (Salvelinus namaycush) (Post and Johnston 2002).

The extinction of the Banff longnose dace Rhinichthys cataractae smithi was attributed partly to the introduction of tropical fish into the warm pond that formed its only habitat. "Western mosquitofish, a warmwater exotic, and the tropical fishes sailfin molly and African jewelfish, all long established in the Cave and Basin Hotsprings marsh, have been implicated in the extinction of the Banff longnose dace " (Mayhood 1995).

Fish communities of the Alberta boreal and parkland lake systems, and of prairie river systems, are relatively pristine compared to those of other regions across North America. No non-native species stocked for sport fisheries have become established with the possible exception of smallmouth bass, Micropterus dolomieu Lacepède, possibly persisting in Island Lake after introductions began in 1977.

The introduction of exotic species such as purple loosestrife and common carp is cited as a possible factor in the decline of the northern leopard frog Rana pipiens. Common carp is not present in Alberta and purple loosestrife is rare, so these particular species are unlikely to be involved. In British Columbia, the alteration of waterways and the introduction of game fish are also thought to have contributed to the decline of the frog (Environment Canada 2003). However the factors responsible for the decline of the northern leopard frog in Alberta are not well understood. The role of sport fish introductions is unknown but is cause for concern (Krendell and Wagner 2003).

\subsubsection{Invertebrates}

The virile crayfish, Orconectes virilis (Hagen), is native to eastern Alberta and was once thought to be localized to Beaver Lake. Since the 1960s it has moved into the North Saskatchewan River drainage. It is now in the South Saskatchewan drainage near the fork of the Oldman and Bow rivers. Recent sampling has detected this species in great abundance as far west as Devon. Other species of crayfish common in the pet trade have been collected near urban centres but are not thought to be established (M. Sullivan, pers. comm.).

The European Ear Snail, Radix auricularia (Linnaeus), has been recorded from Banff (Clarke 1981). It inhabits lakes, ponds, and slow-moving rivers with a preference for muddy substrates. The impact of this species is also unknown.

An indirect impact from movement of native species to a new drainage is exhibited by the potential damage to the lake whitefish, C. clupeaformis (Mitchill), fishery due to the cestode worm, Triaenophorus crassus Forel. This worm infects adult Northern Pike, Esox lucius L., when the pike ingest infested Cisco, Coregonus artedi Lesueur. The Ciscos are infected when they ingest infested copepods, which, in turn, were infected by consuming the immature stages of the worm originating from $T$. crassus eggs discharged by infected Pike. It is presumed that infected Ciscos were transported from northern to southern Alberta during a transplantation of Walleye, Stizostedion vitreum vitreum (Mitchill). Lake whitefish are an alternate host of $T$. crassus. The presence of the worm reduces the marketability of the whitefish and has the potential to reduce the whitefish fishery from $\$ 2$ million to $\$ 100,000$ /year. (Nelson and Paetz 1992; M. Sullivan, pers. comm.) 


\subsection{Plant and wildlife diseases}

As far as can be determined, introduced plant diseases currently have little impact in forest or rangeland ecosystems in Alberta. A major exception is white pine blister rust, which is having devastating effects on limber and whitebark pine with consequent impacts on wildlife and ecosystem function. Introduced diseases are important in agriculture, and some of these may have effects on native species and natural ecosystems, but no studies have been done to assess these impacts. Several possible disease threats to Alberta forests have been identified.

Introduced diseases have major potential for effects on native wildlife and on livestock in Alberta. West Nile virus may produce extensive mortality in corvid populations, while brucellosis and bovine tuberculosis have the potential for major effects on cattle productivity as well on access to markets.

The woodland caribou is potentially threatened by parasitic brainworms from invasive whitetailed deer. The wood bison Bison bison athabascae is seriously affected by exotic bacterial diseases (anthrax, brucellosis, and bovine tuberculosis) which are largely responsible for its threatened status and have complicated recovery programs for this species. These diseases are considered to be "the most difficult issue facing management and recovery of wood bison in Alberta" (Mitchell and Gates 2002).

\section{INTRODUCTION PATHWAYS}

\subsection{General}

Introduction pathways for exotic species can broadly be divided into intentional and accidental modes. Intentional introductions include plant species brought in as crops or ornamentals, or introduced in efforts at erosion control or reclamation, domestic livestock and pets, introduced game animals and sport fish, and biological control agents. Most introduced plants in the United States are the results of deliberate introduction (Mack and Erneberg 2002) although some are thought to have entered as seed contamination. Accidental introductions are species that arrived as contaminants with imported goods such seeds, plants, soil, machinery, or farm animals, as hitch-hikers on ships and vehicles, in shipping containers and packing materials.

The original introduction pathway into North America is not necessarily the same as that through which species later arrive in interior landlocked areas such as Alberta. Once established in a continental area, introduced species may move around through natural dispersal or deliberate or accidental human movement, regardless of their original mode of introduction. The European gypsy moth, for example, was originally a deliberate release from experimental rearing in Massachusetts in 1869 and has since spread by natural dispersal over most of eastern North America. The West Nile virus has spread rapidly over most of North America since its introduction, through the movement of infected birds and mosquitoes.

\subsection{Past introductions into Alberta}

The rate of establishment of new non-native plants in Alberta is relatively low. Figure 2 shows the cumulative number of exotic vascular plant species known from Alberta since 1959 (Moss 1959; Packer 1974; Moss and Packer 1983; Kartesz 1999; Alberta Native Plant Council 2000). Numbers are approximate, as nomenclatural changes and taxonomic revisions in some cases 
make it difficult to trace the first date at which a species was recorded. The date of first establishment of a species in many cases will be much earlier than when it was first reported in floras. Moss (1959) lists 181 introduced species in Alberta. During the 1960s and 1970s, 49 more species were added, and Moss and Packer (1983) listed 71 previously unreported introduced species. Many of these were likely due to better knowledge of the flora and taxonomic revisions, rather than representing new arrivals in the province during that period. In the twenty years since Moss and Packer (1983), only seven additional introduced species have been recognized, mostly rare or of uncertain status in the province. All plant species identified as major invasives in this report were present in Alberta by 1959, and in most cases much earlier, although most of them have probably greatly increased in numbers since then. The vast majority of the species listed as invasive in Table 3 were also already present in Alberta by 1959.

Thus most of the species which are currently invasive in the province have been present since at least the early or mid 20th century, and concern arises because these existing species are expanding their range and abundance, rather than from the frequent appearance of new invaders. Information on the original modes of introduction of these species to Alberta is scarce and often anecdotal; for instance local oral history reports that leafy spurge was introduced to the Hardisty area as a seed contaminant in feed for mules during the construction of the Canadian Pacific Railway line in 1906 (T. Dietzler, pers. comm.). Transportation corridors may provide a primary means of entrance and spread for some weeds. For instance, knapweed infestations in Alberta have tended to occur along railway lines (pers. comm. S. Ali, AAFRD).

The main threat is the expansion and dispersal of existing populations within the province. Possible introduction pathways for new species include importation of crop and ornamental seed, including "wildflower" mixes, movement of contaminated hay, vehicles, and along transportation corridors. The most likely new invaders are species already present in surrounding jurisdictions. Some of these have been identified in this report, but there are too many others to enumerate here.

\subsection{Potential sources of new introductions}

\subsection{1. $\quad$ Trade}

As Alberta's economy becomes increasingly globalized, the opportunities for introduction of invasive species through inadvertent entry with imported goods increase. Some idea of the possible pathways of introduction in the course of trade can be gained from examining trade statistics in conjunction with the climatic and environmental conditions of the areas from which imports originate (Curnutt 2000; Perrault et al. 2003). Greater volumes of trade increase the likelihood that exotic species will be introduced, while similarity of climates increases the likelihood that these species will establish and become invasive if they enter Alberta.

Figure 3 shows the distribution of climatic matches with Alberta according to CLIMEX. As would be expected, the closest matches are found with adjacent areas of Canada and the United States. Other climates matching Alberta's at above the $50 \%$ level are found in a broad band from central and northern Europe, through Russia and the Caucasus, southern Siberia and central Asia, and into northern and central China. Isolated locations showing a lower degree of matching are found in western Europe, North Africa, and in South America at high elevations and the extreme south. Although this overall climate match is a crude tool for predicting the 
likelihood of establishment of individual exotic species, the map does suggest that particular attention should be paid to the risk of exotic species introductions from these areas.

According to Industry Canada statistics, over the period 1998 - 2002 Alberta received imported goods worth almost $\$ 11.7$ billion per year. (All figures are yearly averages in Canadian dollars based on 1998 - 2002 data, excluding re-imports of Canadian products.) These imports came from 206 countries. (In contrast, there are currently 191 member countries of the United Nations. The discrepancy arises because of some territorial subdivisions listed separately in the Industry Canada database that are not politically independent.) This indicates that Alberta's trade connections are worldwide, and that invasive species can potentially arrive with trade shipments from any part of the world. However, the volume of trade with many of these countries is very small (less than $\$ 100,000$ per year for 120 countries). The United States is the source for the vast majority $(76.7 \%)$ of imports into Alberta. Only nine other countries (Mexico, the United Kingdom, Germany, Italy, Japan, China, France, Taiwan, and South Korea) provide more than $\$ 10$ million of imports to Alberta each year. If imports are broken down on a regional basis, most imports come from, in order, the United States, Western Europe, East Asia, Central America (including Mexico), and Southeast Asia (Figure 4). Lower import volumes come from South America, Australasia, Eastern Europe, and the Middle East. Imports to Alberta from Africa, Russia and Central Asia, Oceania and others are minimal.

Figure 5 places Alberta's imports from other countries in perspective with interprovincial trade. This shows that although the United States is the largest single source of imports into Canada, most of the rest of the province's import trade actually consists of imports from other Canadian provinces. Thus the major areas of origin for imports to Alberta that have well-matched climates are adjacent areas of Canada and the United States, some parts of western Europe, and China. This suggests that new invasive species are most likely to be introduced from these areas.

Some specific categories of imports likely to be associated with risks of exotic species introductions were examined. For almost all of these categories, the United States was the largest source of imports into Alberta. Other major import sources were:

- $\quad$ fresh fruits and vegetables from Mexico, parts of Europe, and some South and Central American countries

- $\quad$ live trees and other plants (including cut flowers) from the Netherlands, South and Central America, New Zealand, and Mexico seeds for planting, particularly from western Europe and China, with other occasional imports from almost every region of the world live fish from numerous countries in Southeast Asia

- $\quad$ live fish from numerous countries in Southeast Asia

- wood products of many kinds, particularly crates and packing materials from many countries in Europe, South America and Asia.

The Canadian Food Inspection Agency statistics for quarantine interceptions on import shipments over the period 1997-2000 are shown in Figure 6. British Columbia and Nova Scotia have disproportionately high rates of interceptions in relation to their import volumes, reflecting the importance of maritime trade arriving at Vancouver and Halifax. Ontario and Quebec also have relatively high volumes of imports and interceptions. It is not surprising that these locations have been associated with recent detections of exotics such as the Asian 
longhorn beetle in Toronto, the brown spruce longhorn in Halifax, and the Asian gypsy moth in Vancouver. In contrast, Alberta's import volume is relatively low compared to the major importing provinces, and the number of interceptions is correspondingly fairly low.

\subsubsection{Natural dispersal}

Natural dispersal of invasive species from adjacent areas of the continent also presents significant threats. For example, salt-cedars (Tamarix spp.) which were originally introduced into the United States as ornamentals, are spreading rapidly in the Northwestern United States, aided by their windblown seed. Natural spread of this species presents a significant risk of its establishment in southern Alberta (Sexton et al. 2002; Pearce and Smith 2003).

\subsubsection{Recreation}

Major invasions of many exotic aquatic species have occurred in the Great Lakes system. Although there are no direct water flows connecting Alberta to the Great Lakes, vigilance is required to prevent introduction of these species into Alberta. A possible introduction pathway from this region is the movement of recreational watercraft. However, most recreational travel originates in Alberta with travel to the adjoining provinces of B.C. and Saskatchewan and some travel to Manitoba.

The movement of live bait into Alberta is another potential source of invasive alien species. This mechanism has not been well studied. Although the use of live bait for sport fishing is illegal in Alberta, importation and use of live bait, especially leeches from Minnesota and dew-worms, is commonplace. This gives rise to potential invasion risks both of the bait species themselves as well as other aquatic organisms that may be inadvertently introduced with them. The status of introduced leeches is not well documented and should be addressed.

Two related potential sources of invasive alien species are the release of aquarium fish and associated species in water, and live fish imports for the food trade. The latter is believed to have been the source of recent well-publicized findings of the Asian snakehead fish, Channa argus, in the United States.

\subsection{4. $\quad$ Seed}

As indicated above, Alberta imports "seeds for planting" from almost every part of the world. From an invasive species viewpoint, a particular concern is with plant seed (mainly grasses and legumes) used for revegetation, pasture, range and reclamation purposes, as this is seeded over large areas in both agricultural land and natural areas of the province. Native and agronomic plant seed for these purposes is grown both inside and outside Alberta (S. Foster-Stubbs, pers. comm, 2004). Within the province, most of the native plant seeds sent for analysis to 20/20 Seed Labs originate in southern Alberta (e.g. Vulcan, Lethbridge, Nobleford, Coutts, and Sweetgrass. The bulk of seeds sourced outside Alberta originate in Montana and California, both areas with major infestations of many invasive plant species not present in Alberta. Seed is graded, bought, and sold in Canada based on the Canada Seeds Act. Under the Act, several grades of seed permit certain levels of weed seed impurities. As a consequence, contamination of seed can serve as a route of introduction of invasive plants into Alberta, as well as a means for redistribution within the province. According to data collected by 20/20 Seed Laboratories, contamination of native grass seed lots with seeds of restricted weeds is more frequent than 
such contamination of agricultural crop seed. This may be due to difficulties in cleaning native seeds, sourcing from outside Canada, and sourcing in areas where restricted weeds are commonly found. For example, Jimsonweed (Datura stramonium) and Death Camas (Zigadenus fremontii (native)) are frequently identified in native grass seed lots, but are rare in other types of seed (S. Foster-Stubbs, pers. comm, 2004). Introduction of invasive and weed plant species as seed contaminants to Green and White Area public lands is at least partially limited by recommendations for seed purity contained in the Native Plant Revegetation Guidelines for Alberta (Sinton-Gerling 2000).

\section{POTENTIAL THREATS}

The following threats were identified:

Vascular plants

Terrestrial vertebrates

Terrestrial invertebrates

Aquatic organisms

Plant and wildlife diseases
Salt-cedar, Tamarix ramosissima Ledeb., T. chinensis Lour., and their hybrids

Yellow star-thistle, Centaurea solstitialis L.

Garlic mustard, Alliaria petiolata (Bieb.) Cavara \& Grande

Common crupina, Crupina vulgaris Cass.

Exotic deer species

Swine (wild boar), Sus scrofa

Asian longhorn beetle, Anoplophora glabripennis

Brown longhorn beetle, Tetropium fuscum $\mathrm{F}$.

Larger European pine shoot beetle, Tomicus piniperda L.

Asian gypsy moth, Lymantria dispar (L.)

Whirling disease, Myxobolus cerebralis

Spiny water flea, Bythotrephes cederstroemi

Eurasian water-milfoil, Myriophyllum spicatum L.

Lyme disease

Parasites from exotic cervids

Chronic wasting disease

Bronze leaf, Apioplagiostoma populi

European larch canker, Lachnellula willkommii

Sudden oak death, Phytophthora ramorum

\subsection{Terrestrial plants}

\subsubsection{Salt-cedar}

These Asian trees were introduced as ornamentals and are now major invaders of riparian ecosystems throughout the western United States. Their extensive ecological impacts include lowering of water tables, displacing native trees and shrubs, and salinization of soil (DiTomaso 1998). The irrigation value of this water loss is estimated at US\$39 million to US\$121 million annually (Zavaletta 2000). They are currently spreading rapidly in Montana (Pearce and Smith 2003), and are probably climatically adapted to allow spread into climates similar to that of Alberta (Sexton et al. 2002). Tamarix species are sold as ornamentals in Alberta, and the Alberta Weed Advisory Committee has expressed concern about the potential for this to lead to their establishment in the province. 


\subsection{2. $\quad$ Yellow star thistle}

Yellow star-thistle is a winter annual native to the Middle East and south central Europe. It can form dense impenetrable stands that displace desirable vegetation in natural areas and rangelands. The plant can grow $1-2 \mathrm{~m}$ tall and the flower heads bear long sharp spines that deter cattle and wildlife grazing. It is lethally toxic to horses. Yellow star thistle is widespread in California, Washington, Oregon, Idaho and Montana (DiTomaso 2002). It has been declared a restricted weed in Alberta. A yellow star thistle seed was recently found in a package of ornamental "wild flower seeds" purchased in British Columbia (pers. comm. P. O'Hara, M.D. of Fairview).

\subsubsection{Garlic mustard}

This biennial European member of the mustard family has spread rapidly through deciduous forests in the northeastern US and adjacent Canada, forming a virtual monoculture and displacing native understorey species (Anderson et al. 1996; Nuzzo 1999). Garlic mustard is found in British Columbia and a recent study suggests that forests in some parts of Alberta would be within the climatic range of the species (Welk et al. 2002).

\subsubsection{Common crupina}

This is an annual plant related to the knapweeds and native to southern Europe. The first infestation was discovered in Idaho in 1969 and within 12 years it had spread to cover 23,000 acres. It is unpalatable to livestock when mature and can form solid stands which decrease rangeland carrying capacity. Although the climatic requirements and potential distribution of common crupina are not fully known, it can grow under a wide range of temperature and photoperiod conditions (Patterson and Mortensen 1985). Its rapid spread in Idaho indicates that its introduction into Alberta would be a serious concern.

\subsection{Terrestrial vertebrates}

\subsubsection{Exotic Deer Species}

Exotic deer species are a threat to the genetic purity of native species. Red deer can survive in the wild and mix with native elk species. Exotic deer also are a threat in potential introduction of disease that can affect native populations for example chronic wasting disease. Potential helminths that could be imported that could harm native ungulates include meningeal worm (Parelaphostrongylus tenuis), caribou muscleworm (Parelaphostrongylus andersoni), dorsal-spined larvae (Varestronglyus alpenae), tissue worms (Elaphostrongylus spp.), and Besnoitia, a protozoan parasite (Pybus 1999).

\subsubsection{Invasive Swine}

Pimentel et al. (1999) estimated there were 4 million invasive swine (Sus scrofa) in the US. Bergman et al. (2002) reported established populations in 29 states and 1 territory. In Canada, escaped wild boar have established populations all across southern Manitoba. They impact private property and seriously damage native flora and fauna through their aggressive behaviour and phenomenal reproductive capability (Manitoba Conservation ). Small populations have tried to establish in Alberta near Sundre and Lac Ste. Anne but have been or are being controlled. 


\subsection{Terrestrial invertebrates}

\subsection{1. $\quad$ Mountain pine beetle}

This insect, Dendroctonus ponderosae Hopkins, is the single most destructive forest pest in Western Canada. Adult mountain pine beetle attack lodgepole, Pinus contorta Dougl. var. latifolia Engelm., and limber pine, Pinus flexilis James. Larval feeding under the bark results in girdling and, in some cases, blue-stain fungi also contribute to tree mortality. Infestations have been on the increase in Banff National Park with 5,000-10,000 lodgepole pine expected to be killed in 2003. The infestation has moved beyond the boundaries of BNP into the Canmore area. Infested trees have been reported in Jasper National Park and the Willmore Wilderness Area. Infestations are expected to increase and spread in all currently infested areas in 2003 and beyond. It was presumed that harsh Alberta winters held the MPB distribution to the western slopes of the Rockies. Climate has been reported to be a major limiting factor in the northern distribution of the MPB (Amman 1977). It is feared that increasing winter temperatures will allow this species to spread throughout the eastern slopes and farther west. British Columbia is suffering through its worst MPB infestation with 1.46 million hectares affected. A similar devastating impact could be felt by the Alberta logging industry. The lodgepole pine stands in Alberta have not been subjected to constant MPB pressure throughout its establishment and development. Flora, fauna, soil, and watershed quality would feel the impact of widespread tree mortality due to MPB. The montane forest ecosystem would be significantly changed if an MPB outbreak went unchecked.

\subsubsection{Asian longhorn beetle}

Anoplophora glabripennis, a native of China, was discovered in the eastern USA in 1996 and appeared near Toronto in 2003. This wood-boring beetle has the potential to infest and severely damage hardwood species such as poplar (Populus spp.), willow (Salix spp.), and ash (Fraxinus spp.) across Canada. Adults feed on the bark of twigs and the larvae bore into the heartwood of the tree.

\subsubsection{Brown longhorn beetle}

Tetropium fuscum F., a native of Europe was detected in Halifax in 1999. This insect prefers to attack spruce (Picea spp.) but has been recorded from fir (Abies spp.), pine (Pinus spp.) and larch (Larix spp.). The larvae bore into the phloem and then feed parallel to the bark. Both damaged and, in an outbreak, healthy trees are attacked.

\subsubsection{Larger European pine shoot beetle}

Tomicus piniperda L. is distributed across 12 north central and north eastern United States, and Ontario, and Quebec. The primary host plant is pine (Pinus). It has been isolated from Scots pine (Pinus sylvestris L.), Red pine ( $P$. resinosa L.), Jack pine ( $P$. banksiana L.), Eastern white pine ( $P$. strobus L.) and Austrian pine (P. nigra L.). It has also been reported from logs of spruce (Picea spp.), fir (Abies spp.) and larch ( Larix spp.). This insect has one generation per year with adult feeding on shoots being the most destructive stage (Kennedy and McCullough 2002).

\subsubsection{Asian gypsy moth}

Lymantria dispar (Linnaeus). Sampling and survey programs exist for the detection of this pest. Asian Gypsy Moth was detected in Edmonton in 2003 but is not believed to be established. 


\section{4. $\quad$ Aquatic invasive species}

\subsubsection{Whirling disease}

This disease, caused by the protozoan Myxobolus cerebralis, is a serious threat to trout and whitefish in Alberta (Government of Alberta 2002). The disease infects cutthroat, rainbow, and brook trout, mountain whitefish, and salmon. Bull and brown trout are partially resistant. Grayling are very resistant. The adult fish is infected when the parasite burrows through the body wall and lodges in cartilage causing deformities and nerve damage which may result in characteristic tail-chasing behaviour. When the host fish dies spores are released that are then taken up by the alternate host, Tubifex tubifex. The parasite completes the next phase of its life cycle within the worm host and is then emerges in the infectious stage. Adult fish can also contract the disease by ingesting infested tubifex worms.

The disease organism is most effectively dispersed by transport of live fish and fish parts. The spores can survive transit through the digestive tract of birds and can survive in mud contaminating watercraft and fishing gear (Whirling Disease Foundation 2001). The disease has been detected in the Missouri River drainage in Montana. Effort should be made to prevent the introduction of fish, fish material or transport of contaminated equipment from affected areas. The impact of this disease on trout and whitefish stocks in Alberta is unknown but precipitous reductions in populations have resulted in some rivers in Montana (Whirling Disease Foundation 2001).

\subsection{2. $\quad$ Spiny water flea}

Bythotrephes cederstroemi was introduced into the Great Lakes, specifically Lake Huron, in 1984 and all of the remaining Great Lakes by 1987 (Berg 2003). It is uncertain how this species might affect fish populations in Alberta were it to be introduced. The likelihood of this species being introduced is low considering the Great Lakes are not directly connected to Alberta river drainages and the majority of watercraft transport consists of Albertan craft traveling within the prairie region and not to the Great Lakes.

\subsubsection{Eurasian water milfoil}

Eurasian water milfoil (Myriophyllum spicatum) is a submersed aquatic plant native to Europe, Asia, and northern Africa that grows in fertile lakes and waterways and is easily spread on boating and fishing equipment. It may have been introduced to North America as an aquarium plant (White et al. 1993). It can form a dense underwater canopy that can shade out and displace native aquatic plant species (Boylen et al. 1999). The masses of vegetation interfere with fishing, boating, swimming, and irrigation, and can obstruct water intakes for industrial use and power generators. Eurasian water milfoil is widespread across the northern US and Canada, occurs in parts of British Columbia, Ontario, and Quebec and will probably continue to expand its range in Canada (White et al. 1993). It is a restricted weed in Alberta.

Other potential problems in southern Alberta include the introduction of the Asian or grass carp, Ctenopharyngodon idella (Valenciennes), and the possibility of invasion of the common or European carp, Cyprinus carpio Linnaeus. Triploid grass carp with reduced capacity for reproduction have been introduced into southern Alberta for weed control. Reproductive diploids have been discovered in the United States and it may only be a matter of time before a 
similar transformation occurs to Alberta stocks. Indiscriminate movement of stocks by farmers from closed dugouts and irrigation canals may result in inadvertent releases into river drainage systems.

The European carp is present in the Missouri river drainage and therefore the potential for introduction into the Milk River drainage system from Montana exists. Alberta is possibly the only North American jurisdiction without established populations of the European carp (M. Sullivan, pers. comm.). This species has been recorded from Saskatchewan but currently not from the South Saskatchewan River.

\subsection{Plant and wildlife diseases}

\subsubsection{Bronze leaf}

This European disease, caused by the ascomycete Apioplagiostoma populi, has recently been reported in Manitoba (Northover and Desjardins 2003). Its route of introduction and impact are unknown but the ecological and economic impacts are potentially great if the disease spreads to native aspen stands. Hybrid and non-native poplars (e.g. Populus $\mathrm{x}$ canescens) are more susceptible than native poplars (Smith et al. 2002).

\subsubsection{Sudden oak death}

The geographic origin of sudden oak disease, caused by the oomycete Phytophthora ramorum, is unknown. North American and European populations are distinct, transported independently from a common point of origin. It has caused major damage to several oak species in California but has a wide host range (California Oak Mortality Task Force 2002). Alberta species known to be within its host range include Douglas fir, Pseudotsuga menziesii, and hazelnut, Corylus cornuta (Davidson et al. 2002). Sudden oak death was identified on a single rhododendron plant in British Columbia in 2003. Its economic impact could affect plant imports and exports, and the horticulture industry. Its ecological impact is unknown; the disease may be sub-lethal on Alberta plant species.

\subsubsection{European larch canker}

European larch canker is caused by the ascomycete Lachnellula willkommii Larix spp. and was detected in Canada in 1980 (Humble and Allen 2001). It currently occurs in parts of Nova Scotia, New Brunswick and Prince Edward Island. Potential losses in the USA are estimated to be \$US 25-240 million. Its potential for ecological impact in Alberta is unknown. The host range of the pathogen includes tamarack, Larix laricina (Yde-Andersen 1979), but the pathogen may not be adapted to Alberta's climate (McKenney et al. 2003).

\subsubsection{Lyme disease}

Lyme disease, caused by the spirochaete Borrelia burgdorferi, has not yet been confirmed in Alberta. This bacterium is most likely to occur in the foothills, mountains, and aspen parkland areas where the species of ticks most responsible for its transmission are most common. This disease has been in Europe since the early 1900's. It was unknown in North America but within the last 20 years has been reported extensively in the U.S. It is spread by arthropods, usually ticks. The economic impact is associated with human health related costs. The ecological impact is uncertain but it affects humans, horses and dogs. There is a potential to affect wild canids (Brandt et al. 1995; Centers for Disease Control 2003). 


\subsection{5. $\quad$ Parasites from Exotic Cervids}

As mentioned above, parasites from exotic cervids could damage native wildlife populations.

Potential helminths that could be imported that could harm native ungulates include meningeal worm (Parelaphostrongylus tenuis) (Mortensen and Woodbury 1999), caribou muscleworm (Parelaphostrongylus andersoni), Dorsal-spined larvae (Varestronglyus alpenae), Tissue Worms (Elaphostrongylus spp.), and Besnoitia, a protozoan parasite (Pybus 1999; Samuel et al. 2001). Parelaphostrongylus tenuis is present in eastern and central Canada but has so far not spread further than eastern Saskatchewan. White-tailed deer (Odocoileus virginianus) are the normal host and are not affected by the worm, but they shed the larvae which are picked up by slugs and snails and in turn ingested by mule deer (Odocoileus hemonius), elk (Cerous elaphus) and moose (Alces alces), which are not the normal host. $P$. tenuis can cause significant mortality among these cervids (Mortensen and Woodbury 1999).

\subsubsection{Chronic Wasting Disease}

This prion poses a serious economic and ecological threat. The economic threat is associated with the potential reduction in hunting and outfitting in Alberta. Ecological effect is the potential impact on Alberta's native elk and deer. 


\section{OVERALL EVALUATION}

\subsection{Taxonomic groups of invasive species present in Alberta}

The invasive flora and fauna of Alberta are very unequally distributed across taxonomic groups in terms of the species present, their impacts, and our level of knowledge. The best-known group of invaders is the vascular plants, with around 50 documented invasive species. Many insect species are known to be introduced in the province, but their effects, with few exceptions, have been little studied, so their status as true invasive species is unclear. Only a few invasive terrestrial vertebrates are present. Few introduced fish species are established, although some of them have major impacts. There are very few records of invasive aquatic invertebrates. A limited number of plant and wildlife diseases are known from the province, but some of them have significant ecosystem-level effects.

\subsection{What is an invasive species? - special cases}

This review of invasive species in Alberta has raised some questions of the classification of species as invasive aliens. Two cases are worth discussion: the movement of species within the province to areas where they did not naturally occur, and situations where human activities are modifying the environment in ways that allow species native to adjacent areas to Alberta to expand their range into the province. These can be illustrated through discussion of the movement of aquatic species between separate drainage basins in the province, and the effect of climate on the distribution of the mountain pine beetle.

\subsubsection{Movement within the province}

The native range of a species may be more restricted than the whole province of Alberta. This is particularly likely to occur when there are significant natural barriers within the province, as occurs for aquatic species restricted to particular drainage basins. In such cases a species introduced into an area within the province where it did not naturally occur would effectively be an exotic species, and could potentially have similar impacts to those resulting from the introduction of species from outside the province. The spread of the crayfish Orconectes virilis is apparently an example of such an "intra-province" invasion, although little is known of its impacts.

\subsubsection{Environmental changes}

Mountain pine beetle, Dendroctonus ponderosae Hopkins (MPB), is native to the western USA and British Columbia, where it is a major disturbance factor in pine forests (Amman et al. 1989). MPB is limited in the northern extent of its range by its lack of tolerance to winter temperatures below $-40^{\circ} \mathrm{C}$ (Bentz and Mullins 1999), and by the need for warm enough summer temperatures to complete its development within one year. Recent warm conditions in British Columbia have contributed to the development of a large-scale MPB outbreak (Natural Resources Canada 2003), and modelling suggests that continuation of this warming trend could result in a major northward and eastward expansion of the range of MPB (Logan and Powell 2001; Natural Resources Canada 2003). Such expansion could bring MPB into the distribution range of jack pine, across the northern parts of the prairie provinces and into the Great Lakes region.

Infestations of MPB have been recorded within Alberta from as far back as 1940, with recent outbreaks in 1976 and presently (Cerezke and Petty 1980; Olson + Olson Consulting 2001). The native range of $\mathrm{MPB}$ appears to extend up to, and east of, the Alberta-BC border. A distribution 
map produced by the USDA Forest Service shows the range extending quite far into Alberta (Amman et al. 1989). If it is spilling over the border now, and has done so in the past, these marginal areas are within the normal range of fluctuation and should be counted as part of its historic or natural distribution. Thus, MPB in the border areas of Alberta is currently a native species on the edge of its range.

However if, as a result of human activities, MPB expands further into Alberta and maintains populations in areas where it has never persisted before, this can be considered "movement by human agency, indirect or direct" (United Nations Environment Program 2002). Such expansion could result from actual carrying of the beetles by human activities such as movement of logs, vehicles, etc. ("direct human agency"), or in response to environmental change due to human activities ("indirect human agency"). Thus, there is a threat that MPB will become an invasive species if its range continues to expand into larger areas of the province.

\subsection{Impacts of invasive species}

\subsection{1. $\quad$ Economic impacts}

The available information on economic impacts of invasive species in Alberta is too fragmentary to permit an overall estimate of dollar costs, as is also the case for Canada as a whole (RNT Consulting 2002). Pimentel et al. (1999) estimated total costs in the USA as at least US\$137 billion. This represents about $1.3 \%$ of the US gross domestic product (GDP) of US\$10.5 trillion (Central Intelligence Agency 2003). Alberta's gross domestic product is around $\$ 150$ billion (Alberta Economic Development 2003), thus on a very crude basis this figure could be extrapolated to give an order-of-magnitude estimate for Alberta of \$2 billion. Given that invasive species problems are generally less severe in Alberta than in most of the USA, total costs are probably well below this figure, possibly in the vicinity of $\$ 1$ billion.

The major economic costs of invasive species in terms of resource development in Alberta are probably due to invasive plant species in rangeland. Leafy spurge has been estimated to cause annual economic losses of $\$ 20$ million in Manitoba, and Canada thistle has been estimated to cost canola producers on the prairies $\$ 320$ million annually (RNT Consulting 2002). Estimates of losses to Canada thistle in rangeland are not available but the species is widespread in pastures in Alberta and can cause grass yield losses of up to twice its own biomass (E. Bork, pers. comm. 2003). Other species such as oxeye daisy, tall buttercup and common tansy also infest significant areas of rangeland in Alberta and reduce their grazing potential. Introduced agronomic species such as Kentucky bluegrass are replacing native grasses in some range types where the native species, such as rough fescue, offer advantages in terms of early season grazing. Rangeland and pasture are the basis for Alberta's $\$ 3.9$ billion beef cattle industry.

Economic costs of invasive species to forestry are currently relatively low in Alberta, as most of the major forest insect pests are native species. This could change significant if invasives such as Asian longhorn beetle or mountain pine beetle become established. The spread of invasive plants, both weeds and escaped agronomics, in northern Alberta could also impact forestry by impeding conifer seedling establishment and reforestation. 
Prevention and eradication programs have resulted in major economic savings, for instance an estimated annual benefit of $\$ 42$ million for the rat eradication program (this report).

\subsubsection{Ecological impacts}

The ecological impacts of invasive species include effects on the survival, abundance and genetic integrity of native species, interspecific interactions (predation, herbivory, etc.), succession, nutrient and carbon cycling, hydrology, and fire regimes. Many invasive plant species in Alberta such as leafy spurge, smooth brome, and spotted knapweed, are capable of crowding out native species, altering the composition of plant communities. This is a concern to managers of conservation areas attempting to preserve the relatively small remaining areas of pristine native plant communities in the province. Some invasive plant species probably also reduce forage quality for wildlife, particularly toxic or distasteful species such as oxeye daisy, common tansy, and tall buttercup. The house sparrow, European starling, and seven-spot lady beetle also displace native species by competition for food or nest sites.

Invasive plants may influence soil nutrient cycles and carbon sequestration (Ehrenfeld 2003). Some studies (Christian and Wilson 1999) suggest that replacement of native grasses by crested wheatgrass on the prairies has been responsible, due to its lower root biomass, for the release to the atmosphere of around $4 \times 10^{8}$ tonnes of carbon that would otherwise have been stored in the soil. This implies a possible role for invasive species in global climate change. Several invasive plant species in Alberta, such as white clover, alfalfa, and yellow and white sweetclover are nitrogen fixers, which may have an influence on soil fertility and successional patterns.

Some invasive species threaten the integrity of native species through hybridization, such as crossing of feral dogs with coyotes and wolves, and introgression of brook trout with native bull trout.

At a global level impact on threatened and endangered species is one of the most significant effects of invasive species (Flather et al. 1994; Richter et al. 1997; Wilcove et al. 1998). In Alberta, 63 species are listed by the Committee on the Status of Endangered Wildlife in Canada either as extinct, extirpated, endangered, threatened, of special concern, or data deficient (COSEWIC 2002). The major threats to most species are habitat loss or degradation due to agricultural practices, industrial development or urbanization. Ten species are believed to be affected to some degree by the impact of exotic species. Examples include predation by feral cats and dogs on the endangered piping plover, the role of introduced tropical fish in the extinction of the Banff longnose dace, and the effects of anthrax, brucellosis, and bovine tuberculosis on wood bison populations in northern Alberta. A feral horse population on the Canadian Forces Base at Suffield posed significant threats to the fragile sand dune ecosystem and to several species at risk, before its relocation in 1994 .

\subsection{Introduction pathways}

\subsubsection{Past introductions}

Invasive species have arrived in Alberta through deliberate introduction, as in the case of escaped agronomics and ornamentals, through natural spread, as in the case of West Nile Virus, 
and by trade, as with introduction of exotic plants as contamination in seeds. The same pathways are also responsible for the dispersal and spread of invasives within the province.

\subsubsection{Future risks}

On grounds of proximity, as well as trade volumes, the most likely pathways for arrival of new invasive exotic species in Alberta appears to be through trade with the United States and with other areas of Canada. These are also the most likely sources for natural dispersal of invaders that have already established in North America. Alberta thus appears more likely to be a secondary recipient of invasive species that have already established in other areas of North America, rather than a primary focus for the establishment of new invaders from other continents. This should allow some scope for the design of monitoring and early warning systems for the detection of invasive species in Alberta, as it limits the number of potential invaders that need to be watched for.

The risk of primary introductions from other continents directly into Alberta, however, should not be disregarded. On the basis of trade volumes and climatic similarity, Western Europe and East Asia are the main potential sources of invasives into Alberta from outside North America.

Aquaculture of alien species, whether of fish such as tilapia or invertebrates such as shrimp, crab and crayfish, has the potential to impact Alberta's fisheries. Although individual risk assessments have been conducted there remains a cumulative risk that approaches certainty when the potential number of aquaculture operations for any given species or for all species is considered. The change in species composition from locally adapted species and strains to exotic or non-locally adapted strains may reduce the sustainability of aquatic communities and the sport fishery. Climate change, hydroelectric projects and agricultural demands will likely have an increasing impact on the river systems of Alberta and non-local species and strains may be less capable of adapting or accommodating the new or increased stresses resulting in reduced populations or extirpation.

\subsection{Knowledge gaps}

\subsection{1. $\quad$ Presence and distribution}

Our knowledge of the presence and distribution of invasive species in Alberta is incomplete in many respects. Surveys for invasive plants have been ad hoc and qualitative, and have focused mainly on species regulated under the Weed Act. No coherent effort to inventory the current range of invasives on a provincial scale has been undertaken, particularly for those invasives relatively new to the province. The extent of exotic plant infestation in rangeland, whether privately owned or provincial, is not well known. The distribution and abundance of escaped agronomics is not well known. There has been no attempt to detect "cryptic" invasions of exotic genotypes within species that are native to the province, such as common reed, Phragmites australis (Saltonstall 2002), and reed canarygrass, Phalaris arundinacea (Gifford et al. 2002), despite the significant impacts that such invasions can produce. No comprehensive listing of introduced invertebrate species in Alberta has been prepared. There has been insufficient sampling in aquatic habitats to detect the arrival of invasive species, particularly invertebrates, and very little is known about the prevalence of introduced plant diseases outside agricultural systems. 


\subsubsection{Impacts}

There is a general lack of economic impact data for almost all invasive species in Alberta. In particular, the economic effects of forage yield and quality losses caused by invasive plant species in rangeland have not been well studied. This would require quadrat sampling and grazing utilization studies in infested pastures, as well as nutritional analysis, palatibility, and toxicity studies of the major invasive plant species. Such data would also be helpful in understanding the effects of invasive plant species on wild ungulates and other herbivores.

The ecological impacts of introduced insects are little known in Alberta. Available information for species such as the European ground beetle and the seven-spot lady beetle suggests that they may be having significant effects on native species biodiversity through competition and predation, but no such studies are available for most of the introduced insects in the province.

Invasive plants may have effects on plant succession in rangeland. Current range management direction in Alberta serves as an illustration of our lack of knowledge about some of these issues. As an alternative to traditional Gleason or Clements views of plant succession Friedel (1991) described a model of vegetation dynamics consisting of vegetation states that change only when environmental transition points are encountered. Several authors have described state transition models for vegetation change in different ecosystems around the world (e.g. Stringham et al. 2003). Within Alberta state transition models have been described for several plant community types (M. Willoughby, pers. comm.). These models include management actions (i.e. grazing, timber harvest, prescribed or natural fire, rest) that lead to transitions. The challenge in these models is elucidating the climatic and time requirements that result in nonanthropogenic (excluding fire) changes in state, particularly those changes leading to desirable plant communities. As an example, Willoughby (2000) described a state transition model for rough fescue grasslands that resulted in rough fescue grasslands becoming infested with Kentucky bluegrass under heavy grazing. The challenge is to understand and facilitate if possible conversion (transition requirements) back to rough fescue dominated grasslands. This fundamental challenge exists for most weed infested native plant communities in Alberta as well as elsewhere.

Other ecosystem-level effects of invasive species, such as effects on nutrient cycling and carbon sequestration, have been little studied in Alberta. It will be important to resolve conflicting findings on the importance of invasive species effects on carbon sequestration (Christian and Wilson 1999; Schuman et al. 2002) and to determine if other invasive species have such effects.

The fundamental ecology of plant invasion, including mechanisms whereby invasives become established as well as mechanisms for control and/or enhancement of native species competitiveness need further elucidation. Characteristics of plant communities that lead to invasion (invasibility) also need further study (e.g. Milbau et al. 2003).

The impact of climate change upon the rate of arrival and establishment of invasive species, and on the effectiveness of control actions to inhibit and/or reverse invasions, may be important but has also been little studied. 


\subsection{Conclusions}

Alberta has until now escaped some of the major impacts of invasive species experienced in other jurisdictions in North America. Factors that have protected Alberta to some extent include our extreme climate and the natural barrier formed by the Rocky Mountains. The fact that Alberta's native biodiversity is lower than that of more temperate areas of North America also means that some host-specific invasive species are not of concern in natural areas in the province. For example the emerald ash borer, Agrilus planipennis Fairmaire (Col.: Buprestidae), currently spreading in Michigan and Ontario, is not a concern to Alberta's forest resources because the province has no native ashes (Fraxinus spp.). The fact that the main watersheds in Alberta drain to Hudson Bay and the Arctic Ocean, and are not connected to the Great Lakes/St. Lawrence and Mississippi drainages, has reduced the risk of spread of aquatic invasives from these basins, which are heavily affected by introduced species brought in by trade and in ballast water (Mills et al. 1993). Alberta's distance from the "traditional" sources of introduction of European species on the east coast of North America has provided a time delay in the arrival of invasive species moving across the continent. Alberta has a good track record with early detection and eradication and containment programs for localized invasions of species such as Norway rats, knapweed and purple loosestrife. These efforts have undoubtedly been highly cost-effective, eliminating the need for costly control operations to deal with these species after they become widespread.

It is important, however not to be complacent. Invasive species established elsewhere in North America and moving across the continent will get here eventually. A small area of southern Alberta, the Milk River basin, is part of the Missouri/Mississippi basin, and may be a potential area of entry for invasive aquatic species established in that watershed. Some protective factors are changing, for example global warming may allow more species to establish, such as the mountain pine beetle. Increased frequency of forest fires, in combination with the spread of invasive plants into forested areas of the province, may provide more opportunities for invasive plants to impede normal patterns of native plant succession. Increased trade and container movement provide more opportunities for introduction and reduce effects of distance. More introductions are to be expected from Asia through entry points on the Pacific coast which are much closer to us than the "traditional" ports of entry for introductions from Europe. Increased economic development in northern Alberta (logging, energy) will provide additional landscape disturbance and opportunity for introduction and spread of invasive plants. More detailed studies of invasive species and their impacts in Alberta, and the development of an invasive species strategy in cooperation with other provinces and levels of government, as well as other stakeholders, will be important steps towards addressing these issues. 


\section{BIBLIOGRAPHY}

Alberta Economic Development. 2003. Highlights of the Alberta Economy: Spring 2003. <http://www.alberta-canada.com/statpub/pdf/news_Highlights2003.pdf> Consulted on January 12, 2004.

Alberta Environment. 2001. The General Status of Alberta Wild Species 2000. Edmonton, AB.

Alberta Native Plant Council. 2000. A rogue's gallery of invasive non-native plants. Alberta Native Plant Council, Edmonton. 9 pp.

Alberta Sustainable Resource Development. 2003a. Alberta Forest Health: Pest

Alerts/Moratoriums: Gypsy moth.

<http:/ / www3.gov.ab.ca/srd/forests/health/a_gypsymoth.html > Consulted on December 17, 2003.

Alberta Sustainable Resource Development. 2003b. Chronic Wasting Disease. <http://www3.gov.ab.ca/srd/fw/diseases/CWD/index.html> Consulted on

Amarasekare, P. 1993. Potential impact of mammalian nest predators on endemic forest birds of western Mauna Kea, Hawaii. Conservation Biology 7: 316-324.

Ambrose, L.G., and S.D. Wilson. 2003. Emergence of the introduced grass Agropyron cristatum and the native grass Bouteloua gracilis in a mixed-grass prairie restoration. Restoration Ecology 11: 110-115.

Amman, G.D. 1977. The role of the mountain pine beetle in lodgepole pine ecosystems: Impact on succession. pp. 3-18 in Mattson, W.J. (Ed.), The Role of Arthropods in Forest Ecosystems. New York: Springer-Verlag.

Amman, G.D., M.D. McGregor, and R.E. Dolph, Jr. 1989. Mountain Pine Beetle. Forest Insect $\mathcal{E}$ Disease Leaflet 2. Updated July 2002 ed. U.S. Department of Agriculture Forest Service. pp.

Anderson, B. 1994. Converting smooth brome pasture to warm-season grasses. pp. 157-160 in Wickett, R.G., P.D. Lewis, A. Woodliffe and P. Pratt (Eds.), Spirit of the land, our prairie legacy: 13th North American prairie conference. Windsor, ON: Windsor, ON: Department of Parks and Recreation.

Anderson, R.C., S.S. Dhillion, and T.M. Kelley. 1996. Aspects of the ecology of an invasive plant, garlic mustard (Alliaria petiolata), in central Illinois. Restoration Ecology 4: 181-191.

Anon. 2002. 2001 Census of Agriculture for Alberta. Agdex 852-1. Alberta Agriculture, Food and Rural Development, Edmonton, AB. 178 pp.

Bailey, K.L., B.D. Gossen, R.K. Gugel, and R.A.A. Morrall, eds. 2003. Diseases of Field Crops in Canada. 3rd ed: Canadian Phytopathological Society. 304 pp.

Bangsund, D.A., and F.L. Leistritz. 1991. Economic impact of leafy spurge in Montana, South Dakota and Wyoming. In Agricultural economics report no. 275. Fargo, ND: Dept. of Agricultural Economics Agricultural Experiment Station North Dakota State University.

BC Statistics. 2000. Interprovincial and international trade flows at producer prices, annual (Millions of dollars).

<http://www.bcstats.gov.bc.ca/data/bus_stat/busind/trade/IntProv.pdf $>$ Consulted on

Behnke, R.J. 1992. Native Trout of Western North America. Monograph 6: American Fisheries Society, Bethesda, MD. 275 pp.

Bentz, B.J., and D.E. Mullins. 1999. Ecology of mountain pine beetle (Coleoptera: Scolytidae) cold hardening in the intermountain West. Environmental Entomology 28: 577-587. 
Berg, D.J. 2003. The spiny water flea, Bythotrephes cederstroemi, another unwelcome newcomer to the Great Lakes. Publication OHSU-FS-049.: Ohio State University.

Bergman, D.L., M.D. Chandler, and A. Locklear. 2002. The Economic Impact of Invasive Species to Wildlife Services' Cooperators. pp. 169-178 in Clark, L., J. Hone, J.A. Shivik, R.A.

Watkins, K.C. VerCauteren and J.K. Yoder (Eds.), Human Conflicts with Wildlife: Economic Considerations. Fort Collins, CO: National Wildlife Research Center.

Bork, E.W., R.J. Hudson, and A.W. Bailey. 1997. Upland plant community classification in Elk Island National Park, Alberta, Canada, using disturbance history and physical site factors. Plant Ecology 130: 171-190.

Bourne, J.B. 1998. Norway rat exclusion in Alberta. pp. 242-246 in Proceedings of the Eighteenth Vertebrate Pest Conference, March 2-5, Costa Mesa. CA. USA

Bousquet, Y., ed. 1991. Checklist of Beetles of Canada and Alaska. Ottawa: Research Branch Agriculture Canada. 430 pp.

Bousquet, Y. 2003. Histerid Beetles Associated with Livestock Dung in Canada. Agriculture and Agri-Food Canada, Eastern Cereal and Oilseed Research Centre. <http://res2.agr.gc.ca/ecorc/histerid/intro_e.htm> Consulted on

Bowes, G.G., D.T. Spurr, A.G. Thomas, D.P. Peschken, and D.W. Douglas. 1994. Habitats occupied by scentless chamomile (Matricaria perforata Mérat) in Saskatchewan. Canadian Journal of Plant Science 74: 383-386.

Boylen, C.W., L.W. Eichler, and J.D. Madsen. 1999. Loss of native aquatic plant species in a community dominated by Eurasian watermilfoil. Hydrobiologia 415: 207-211.

Brandt, C.J., M.J. Pybus, W.B. Ballard, and R.O. Peterson. 1995. Infectious and parasitic diseases of the grey wolf and their potential effects on wolf populations in North America. pp. 642 in Carbyn, L.N., S.H. Fritts and D.R. Seip (Eds.), Ecology and Conservation of Wolves in a Changing World: Canadian Circumpolar Institute.

Butterfield, C., J. Stubbendieck, and J. Stumpf. 1996. Species abstracts of highly disruptive exotic plants. Jamestown, ND: Northern Prairie Wildlife Research Center Home Page. <http://www.npwrc.usgs.gov/resource/othrdata/exoticab/exoticab.htm> Consulted on

Cagan, J. 2002. Introduced Species Summary Project: Brown-headed Cowbird (Molothrus ater). Columbia University. <http://www.columbia.edu/itc/cerc/danoffburg/invasion_bio/inv_spp_summ/Molothrus_ater.htm $>$ Consulted on

California Oak Mortality Task Force. 2002. Sudden Oak Death and the California Oak Mortality Task Force. <http://www.suddenoakdeath.org> Consulted on

Canadian Food Inspection Agency. 1998. Importation into Canada and Movement within Canada, of plants and plant parts of Pinus spp. to prevent the entry and spread of Scleroderris Canker, Gremmeniella abietina (Lagerb.) Morelet, variety abietina (European Race). Animal and Plant Health Directorate: Plant Protection Division. <http://www.inspection.gc.ca/english/plaveg/protect/dir/d-98-02e.shtml> Consulted on

Canadian Food Inspection Agency. 2002a. Intercepted Plant Pests 1997-2000. Centre for Plant Quarantine Pests. <http://www.inspection.gc.ca/english/sci/lab/cpqp/introe.shtml> Consulted on

Canadian Food Inspection Agency. 2002b. Stored Product Pests. Lathridius minutus L. <http://www.inspection.gc.ca/english/plaveg/grains/pesorg/coleoptera/second/lat_ min_e.shtml> Consulted on December 17, 2003. 
Canadian Food Inspection Agency. 2003. Lymantria dispar L. Gypsy Moth. <http://www.inspection.gc.ca/english/sci/surv/data/lymdise.shtml > Consulted on December 17, 2003.

Canadian Forest Service. 2003. White Pine Blister Rust. <http://www.pfc.forestry.ca/diseases/CTD/Group/Rust/rust7_e.html> Consulted on

Canadian Wildlife Federation. 2003. Invasive Species in Canada. <http://www.cwffcf.org/invasive/chooseSC.asp> Consulted on August 14, 2003.

Catling, P.M. 1997. The problem of invading alien trees and shrubs - some observations in Ontario and a Canadian checklist. Canadian Field-Naturalist 111: 338-342.

Catling, P.M., and I. Dobson. 1985. The biology of Canadian weeds. 69. Potamogeton crispus L. Canadian Journal of Plant Science 65: 655-668.

Centers for Disease Control. 2003. Lyme Disease: Vector Ecology. Division of Vector-Borne Infectious Diseases, National Center for Infectious Diseases. <http://www.cdc.gov/ncidod/dvbid/lyme/history.htm> Consulted on

Central Intelligence Agency. 2003. CIA World Factbook. <http://www.cia.gov/cia/publications/factbook/index.html> Consulted on January $12,2004$.

Cerezke, H.F., and J. Petty. 1980. Outbreak of the mountain pine beetle in southwestern Alberta. Information Report NOR-X-March 1980: Canadian Forestry Service.

Chmura, A. 2002. Introduced Species Summary Project: West Nile Virus. Columbia University. <http://www.columbia.edu/itc/cerc/danoffburg/invasion_bio/inv_spp_summ/WestNile.html> Consulted on

Christian, J.M., and S.D. Wilson. 1999. Long-term ecosystem impacts of an introduced grass in the northern Great Plains. Ecology 80: 2397-2407.

Chronic Wasting Disease Alliance. 2003. Learn About CWD. <http://www.cwdinfo.org/index.php/fuseaction/about.main $>$ Consulted on

Clarke, A.H. 1981. Freshwater Molluscs of Canada. National Museums of Canada, Ottawa, ON. $446 \mathrm{pp}$.

Clear, R., and S. Patrick. 2003. Fusarium head blight in western Canada. Canadian Grain Commission. <http://www.grainscanada.gc.ca/Pubs/fusarium/ fusarium-e2.htm> Consulted on

Clements, D.R., D.E. Cole, S. Darbyshire, J.R. King, and A.S. McClay. In press. The biology of Canadian weeds. 1--. Leucanthemum vulgare Lam. Canadian Journal of Plant Science.

Clinton, W.J. 1999. Executive Order 13112 of February 3, 1999: Invasive Species. Federal Register 64: 6183-6186.

Cormier, C.M., T.A. Forbes, T.A. Jones, R.D. Morrison, and D.B. McCorquodale. 2000. Alien invasion: the status of non-native lady beetles (Coleoptera: Coccinellidae) in industrial Cape Breton, Nova Scotia. Northeastern Naturalist 7: 241-247.

COSEWIC. 2002. COSEWIC Species Database. <http:/ / www.cosewic.gc.ca/eng/sct1/searchform_e.cfm> Consulted on January 5, 2004.

Cox, G.W. 1999. Alien species in North America and Hawaii : Impacts on Natural Ecosystems. Island Press, Washington, D.C. xii, 387 pp.

Cummings-Carlson, J., D. Hall, and S. Dahir. 2000. Pest management guidelines for white pine. pp. 31-15 - 31-19 in, Silviculture and Forest Aesthetics Handbook. Madison, WI: Wisconsin Department of Natural Resources. 
Curnutt, J.L. 2000. Host-area specific climatic-matching: similarity breeds exotics. Biological Conservation 94: 341-351.

Danks, H.V. 1988. Insects of Canada: A synopsis prepared for delegates to the XVIIIth International Congress of Entomology (Vancouver, 1988). Biological Survey of Canada: Terrestrial Arthropods. $11 \mathrm{pp}$.

Davidson, J.M., M. Garbelotto, S.T. Koike, and D.M. Rizzo. 2002. First report of Phytophthora ramorum on Douglas-fir in California. Plant Disease 86: 1274.

Davis, J.W., L.H. Karstad, and D.O. Trainer. 1981. Infectious Diseases of Wild Mammals. 2nd ed. Iowa State University Press, Ames, Iowa, U.S.A. 446 pp.

Denton, M. 1997. Carabus nemoralis Müller 1764. Evergreen State College, Olympia, WA. <http://www.evergreen.edu/ants/TESCBiota/Carabidae/DENTON97/genera/CARA BUS/C_nemoralis.HTM> Consulted on

Digweed, S.C., J.R. Spence, and D.W. Langor. 1997. Exotic birch-leafmining sawflies (Hymenoptera: Tenthredinidae) in Alberta: Distributions, seasonal activities, and the potential for competition. Canadian Entomologist 129: 319-333.

Dillman, A.C. 1946. The beginnings of crested wheatgrass in North America. Journal of the American Society of Agronomy 38: 237-250.

DiTomaso, J.M. 1998. Impact, biology, and ecology of saltcedar (Tamarix spp.) in the southwestern United States. Weed Technology 12: 326-336.

DiTomaso, J.M. 2000. Invasive weeds in rangelands: Species, impacts, and management. Weed Science 48: 255-265.

DiTomaso, J.M. 2002. Element stewardship abstract for Centaurea solstitialis L. Arlington, VA: The Nature Conservancy.

Dosdall, L.M., D. Moisey, H. Cárcamo, and R. Dunn. 2001. Cabbage Seedpod Weevil Factsheet. Agdex 622-21. Edmonton, AB: Alberta Agriculture, Food and Rural Development.

Dunn, E.H., and D.L. Tessaglia. 1994. Predation of birds at feeders in winter. Journal of Field Ornithology 65: 8-16.

Ehrenfeld, J.G. 2003. Effects of exotic plant invasions on soil nutrient cycling processes. Ecosystems 6: 503-523.

Elliott, N., R. Kieckhefer, and W. Kauffman. 1996. Effects of an invading coccinellid on native coccinellids in an agricultural landscape. Oecologia 105: 537-544.

Environment Canada. 2000. Canadian Forces Base Suffield National Wildlife Area - History and Status. <http://www.mb.ec.gc.ca/nature/whp/nwa/suffield/dd02s02.en.html> Consulted on January 11, 2004.

Environment Canada. 2003. Species at Risk. <http://www.speciesatrisk.gc.ca/default_e.cfm> Consulted on January 5, 2004.

Flather, C.H., L.A. Joyce, and C.A. Bloomgarden. 1994. Species endangerment patterns in the United States: General Technical Report no. RM-241. Fort Collins, CO, USA: US Department of Agriculture Forest Service, Rocky Mountain Forest and Range Experiment Station.

Floate, K. 2003. Biological Control of Livestock Insect Pests: Dung Beetles. Agriculture and AgriFoods Canada. Lethbridge Research Center.

<http://res2.agr.gc.ca/lethbridge/scitech/kdf/coleopter_e.htm> Consulted on December 17, 2003.

Frankton, C., and G.A. Mulligan. 1987. Weeds of Canada. Rev. 1987. ed. Agriculture Canada, Toronto. 217 pp. 
Friedel, M.H. 1991. Range condition assessment and the concept of thresholds. Journal of Range Management 44: 422-426.

Galatowitsch, S.M., N.O. Anderson, and P.D. Ascher. 1999. Invasiveness in wetland plants in temperate North America. Wetlands 19: 733-755.

Garrison, G.A., A.J. Bjugstad, and D.A. Duncan. 1977. Vegetation and Environmental Features of Forest and Range Ecosystems. Agric. Handb. 475. U.S. Department of Agriculture, Forest Service, Washington, DC. 68 pp.

Gates, N. 1985. A Practical Guide To Sheep Disease Management. News-Review Publishing Co, Moscow, ID. 154 pp.

Gifford, A.L.S., J.B. Ferdy, and J. Molofsky. 2002. Genetic composition and morphological variation among populations of the invasive grass, Phalaris arundinacea. Canadian Journal of Botany 80: 779-785.

Godfrey, E.W. 1986. The Birds of Canada. National Museum of Canada, Ottawa. 595 pp.

Gordon, R.D., and N. Vandenberg. 1991. Field guide to recently introduced species of Coccinellidae (Coleoptera) in North America, with a revised key to North American genera of Coccinellini. Proceedings of the Entomological Society of Washington 93: 845-864.

Gould, J. 1999. Status of the Western Blue Flag (Iris missouriensis) in Alberta: Alberta Wildlife Status Report No. 21. Edmonton, AB: Alberta Environment, Alberta Conservation Association.

Government of Alberta. 2002. Whirling Disease...Potential for Concern! Aquaculture in Alberta. <http://www1.agric.gov.ab.ca/\$department/newslett.nsf/all/aqua59?OpenDocument $>$ Consulted on

Gray, J.P., C.W. Maddox, P.C. Tobin, J.D. Gummo, and C.W. Pitts. 1999. Reservoir competence of Carcinops pumilio for Salmonella enteritidis (Eubacteriales: Enterobacteriaceae). Journal of Medical Entomology 36: 888-891.

Green, E.K., and S.M. Galatowitsch. 2001. Differences in wetland plant community establishment with additions of nitrate- $\mathrm{N}$ and invasive species (Phalaris arundinacea and Typha $\times$ glauca). Canadian Journal of Botany 79: 170-178.

Grilz, P.L., and J.T. Romo. 1994. Water relations and growth of Bromus inermis Leyss. (smooth brome) following spring or autumn burning in a fescue prairie. American Midland Naturalist 132: 340-348.

Grilz, P.L., and J.T. Romo. 1995. Management considerations for controlling smooth brome in fescue prairie. Natural Areas Journal 15: 148-156.

Haeussler, S., L. Bedford, J.O. Boateng, and A. MacKinnon. 1999. Plant community responses to mechanical site preparation in northern interior British Columbia. Canadian Journal of Forest Research 29: 1084-1100.

Harberd, D.J. 1963. Observations on natural clones of Trifolium repens L. New Phytologist 62: 198204.

Hardy BBT Ltd. 1989. Manual of plant species suitability for reclamation in Alberta. Report \# RRTAC 89-4, 2nd ed.: Reclamation Research Technical Advisory Committee.

Harris, P. 2003. Classical Biological Control of Weeds. Agriculture and Agri-Food Canada, Lethbridge Research Centre. <http://res2.agr.gc.ca/lethbridge/weedbio/index_e.htm> Consulted on

Heidinga, L., and S.D. Wilson. 2002. The impact of an invading alien grass (Agropyron cristatum) on species turnover in native prairie. Diversity \& Distributions 8: 249-258.

Hersperger, A.M., and R.T.T. Forman. 2003. Adjacency arrangement effects on plant diversity and composition in woodland patches. Oikos 101: 279-290. 
Holt, N.W., and P.G. Jefferson. 1999. Productivity and sustainability of four grazed grass-alfalfa mixtures. Canadian Journal of Animal Science 79: 83-89.

Howarth, F.G. 1991. Environmental impacts of classical biological control. Annual Review of Entomology 36: 485-509.

Hull, A.C., Jr. 1973. Germination of range plant seeds after long periods of uncontrolled storage. Journal of Range Management 26: 198-200.

Humble, L.M., and E.A. Allen. 2001. Implications of Non-Indigenous Insect Introductions in Forest Ecosystems. pp. 45-55 in Liebhold, A.M., M.L. McManus, I.S. Otvos and S.L.C. Fosbroke (Eds.), Proceedings: integrated management and dynamics of forest defoliating insects; 1999 August 15-19; Victoria, BC. Gen. Tech. Rep. NE-277. Newtown Square, PA: U.S. Department of Agriculture Forest Service, Northeastern Research Station.

Hunter, J.C., and J.A. Mattice. 2002. The spread of woody exotics into the forests of a northeastern landscape, 1938-1999. Journal of the Torrey Botanical Society 129: 220-227.

Hutchins, H.E., and R.M. Lanner. 1982. The central role of Clark's nutcracker in the dispersal and establishment of whitebark pine. Oecologia 55: 192-201.

Hutchison, M. 1992. Vegetation management guideline: Canada thistle (Cirsium arvense (L.) Scop.). Natural Areas Journal 12: 160-161.

Inch, S., and J. Gilbert. 2003. The incidence of Fusarium species recovered from inflorescences of wild grasses in southern Manitoba. Canadian Journal of Plant Pathology 25: 379-383.

Industry Canada. 2003. Trade Data Online. <http://strategis.gc.ca/sc_mrkti/tdst/engdoc/tr_homep.html> Consulted on November 11, 2003.

Ives, W.G.H., and H.R. Wong. 1988. Tree and Shrub Insects of the Prairie Provinces. Information Report NOR-X-292: Canadian Forestry Service.

Kartesz, J.T. 1999. A Synonymized Checklist and Atlas with Biological Attributes for the Vascular Flora of the United States, Canada, and Greenland in Kartesz, J.T. and C.A. Meacham (Eds.), Synthesis of the North American Flora, Version 1.0. Chapel Hill, NC: North Carolina Botanical Garden.

Katovich, S., and M. Mielke. 1993. How to manage eastern white pine to minimize damage from blister rust and white pine weevil: USDA Forest Service.

Kennedy, A.A., and D.G. McCullough. 2002. Phenology of the larger European pine shoot beetle Tomicus piniperda (L.) (Coleoptera :Scolytidae) in relation to native bark beetles and natural enemies in pine stands. Environmental Entomology 31: 261-272.

Kingsbury, J.M. 1964. Poisonous plants of the United States and Canada. Prentice-Hall, Englewood Cliffs, NJ. xiii +626 pp.

Knodel, J.J., and D.L. Olson. 2002. Crucifer Beetle, Biology and Integrated Pest Management in Canola. Publication e1234: North Dakota State University Extension Service.

Koenig, W.D. 2003. European starlings and their effect on native cavity-nesting birds. Conservation Biology 17: 1134-1140.

Krendell, K., and G. Wagner. 2003. Status of the northern leopard frog (Rana pipiens) in Alberta: Alberta Wildlife Status Report No. 9 (Update 2003). Edmonton, AB: Alberta Sustainable Resource Development, Alberta Conservation Association.

Lacey, J.R., C.B. Marlow, and J.R. Lane. 1989. Influence of spotted knapweed (Centaurea maculosa) on surface runoff and sediment yield. Weed Technology 3: 627-631.

Langor, D.W., S.C. Digweed, D.J.M. Williams, J.R. Spence, and C. Saunders. 2000. Establishment and spread of two introduced parasitoids (Ichneumonidae) of the birch leafminer, Fenusa pusilla (Lepeletier) (Tenthredinidae). Biocontrol 45: 415-423. 
Launchbaugh, J.L., and C.E. Owensby. 1978. Kansas rangelands: Their management based on a half century of research. Hays, KS: Kansas State University, Kansas Agricultural Experiment Station.

Lavoie, C., M. Jean, F. Delisle, and G. Letourneau. 2003. Exotic plant species of the St. Lawrence river wetlands: a spatial and historical analysis. Journal of Biogeography 30: 537-549.

Leeson, J.Y., A.G. Thomas, and L.M. Hall. 2002. Alberta Weed Survey of Cereal, Pulse, and Oilseed Crops in 2001, Weed Survey Series Publication 02-1. Agriculture and Agri-Food Canada, Saskatoon, Saskatchewan. 263 pp.

Lehrer, G.F. 1982. Pathological pruning: A useful tool in white pine blister rust control. Plant Disease 66: 1138-1139.

Lesica, P., and S. Miles. 1999. Russian olive invasion into cottonwood forests along a regulated river in north-central Montana. Canadian Journal of Botany 77: 1077-1083.

Lindgren, C.J. 2003. A brief history of Purple Loosestrife, Lythrum salicaria, in Manitoba and its status in 2001. Canadian Field-Naturalist 117: 100-109.

Logan, J.A., and J.A. Powell. 2001. Ghost forests, global warming, and the mountain pine beetle (Coleoptera: Scolytidae). American Entomologist 47: 160-173.

Long, J.L. 1981. Introduced Birds of the World. Universe Books, New York. 528 pp.

Looman, J. 1983. 111 range and forage plants of the Canadian Prairies: Research Branch Agriculture Canada.

Lowe, P.N., W.K. Lauenroth, and I.C. Burke. 2002. Effects of nitrogen availability on the growth of native grasses [and] exotic weeds. Journal of Range Management 55: 94-98.

Luoma, J.R. 1997. Catfight. Audubon 99: 85-90.

MacIsaac, H.J., S. Bandoni, R. Colautti, C. van Overdijk, and K. Amundsen. 2002. Economic Impacts of Invasive Nonindigenous Species in Canada: a Case Study Approach; A report to the Office of the Auditor General of Canada. Windsor, ON: Great Lakes Institute, University of Windsor.

Mack, R.N., and M. Erneberg. 2002. The United States naturalized flora: Largely the product of deliberate introductions. Annals of the Missouri Botanical Garden 89: 176-189.

Magness, J.R., G.M. Markle, and C.C. Compton. 1971. Food and feed crops of the United States. New Jersey: Bul. 828 New Jersey Agr. Expt. Sta.

Maloy, O.C. 2001. White pine blister rust. doi:10.1094/PHP-2001-0924-01-HM. Plant Health Progress Online.

<http://www.plantmanagementnetwork.org/pub/php/management/whitepine/> Consulted on

Manitoba Conservation. Wild boar at large in Manitoba. Wildlife and Ecosystem Protection Branch.

<http://www.gov.mb.ca/conservation/wildlife/problem_wildlife/boar_at_large.html $>$ Consulted on December 17, 2003.

Marler, M.J., C.A. Zabinski, and R.M. Callaway. 1999. Mycorrhizae indirectly enhance competitive effects of an invasive forb on a native bunchgrass. Ecology 80: 1180-1186.

Masters, R.A., D.D. Beran, and R.E. Gaussoin. 2001. Restoring tallgrass prairie species mixtures on leafy spurge-infested rangeland. Journal of Range Management 54: 362-369.

Mattson, W.J., P. Niemela, I. Millers, and Y. Inguanzo. 1994. Immigrant phytophagous insects on woody plants in the United States and Canada: an annotated list. General Technical Report North Central Forest Experiment Station, USDA Forest Service.

Mayhood, D.W. 1995. The fishes of the Central Canadian Rockies Ecosystem. Report No. 950408 prepared for Parks Canada, Banff National Park. Calgary, AB: Freshwater Research Ltd. 
McClay, A.S., J.T. Arnason, J.F. Livesey, and D.V.C. Awang. 2002a. Alberta tansy chemotype survey 1999. Vegreville, AB: Alberta Research Council.

McClay, A.S., H.L. Hinz, R.A. De Clerck-Floate, and D.P. Peschken. 2002b. Matricaria perforata Mérat, scentless chamomile (Asteraceae). pp. 395-402 in Mason, P.G. and J.T. Huber (Eds.), Biological Control Programmes in Canada, 1981-2000. Wallingford, UK: CABI Publishing.

McKenney, D., A.A. Hopkin, K.L. Campbell, B.G. Mackey, and R. Foottit. 2003. Opportunities for improved risk assessments of exotic species in Canada using bioclimatic modeling. Environmental Monitoring \& Assessment 88: 445-461.

Milbau, A., I. Nijs, L. Van Peer, Reheul, D.D. Cauwer, and Benny. 2003. Disentangling invasiveness and invasibility during invasion in synthesized grassland communities. New Phytologist 159: 657-667.

Mills, E.L., J.H. Leach, J.T. Carlton, and C.L. Secorl. 1993. Exotic species in the Great Lakes: a history of biotic crises and anthropogenic introductions. Journal of Great Lakes Research 19: $1-54$.

Mitchell, J.A., and C.C. Gates. 2002. Status of the Wood Bison (Bison bison athabascae) in Alberta: Alberta Wildlife Status Report No. 38. Edmonton, AB: Alberta Sustainable Resource Development, Alberta Conservation Association.

Morrison, S.L., and J. Molofsky. 1998. Effects of genotypes, soil moisture, and competition on the growth of an invasive grass, Phalaris arundinacea (reed canary grass). Canadian Journal of Botany 76: 1939-1946.

Mortensen, C.J., and M. Woodbury. 1999. Parelaphostrongylus (Brainworm) Infection in Deer and Elk. Western College of Veterinary Medicine, Saskatoon, Saskatchewan.

<http://www.usask.ca/wcvm/herdmed/specialstock/elk/diseases/Ptenuis.html> Consulted on

Moss, E.H. 1959. Flora of Alberta. University of Toronto Press, Toronto. 546 pp.

Moss, E.H., and J.G. Packer. 1983. Flora of Alberta. Second ed. University of Toronto Press, Toronto. $687 \mathrm{pp}$.

Myren, D.T., and G. Laflamme. 1994. Tree Diseases of Eastern Canada. Canadian Forest Service, Ottawa. ix, $159 \mathrm{pp}$.

Nantel, P., R. Claudi, and E. Muckle-Jeffs. 2002. Alien Invaders in Canada's Waters, Wetlands and Forests. Canadian Forest Service Science Branch, Ottawa. 320 pp.

Nasser, R., and J. Mosier. 1991. Projections of pet populations from census demographic data. Journal of the American Veterinary Association 198: 1157-1159.

National Invasive Species Council. 2001. Meeting the Invasive Species Challenge: National Invasive Species Management Plan. 80 pp.

Natural Resources Canada. 2003. Climate change and mountain pine beetle range expansion in BC. Information Forestry August 2003: 5.

Neal, M. 2002. Introduced Species Summary Project: House Sparrow (Passer domesticus).

Columbia University. <http://www.columbia.edu/itc/cerc/danoffburg/invasion_bio/inv_spp_summ/Passer_domesticus.htm> Consulted on

Nelson, J.S., and M.J. Paetz. 1992. The Fishes of Alberta. University of Alberta Press, Edmonton, Alberta. 437 pp.

Nernberg, D., and M.R.T. Dale. 1997. Competition of five native prairie grasses with Bromus inermis under three moisture regimes. Canadian Journal of Botany 75: 2140-2145. 
Niemela, J., and J.R. Spence. 1999. Dynamics of local expansion by an introduced species: Pterostichus melanarius Ill. (Coleoptera, Carabidae) in Alberta, Canada. Diversity \& Distributions 5: 121-127.

Northover, P.R., and M. Desjardins. 2003. First report of bronze leaf disease on hybrid poplar (Populus $\times$ canescens 'Tower') caused by Apioplagiostoma populi in Manitoba, Canada. Plant Disease 87: 1538.

Nuzzo, V. 1999. Invasion pattern of herb garlic mustard (Alliaria petiolata) in high quality forests. Biological Invasions 1: 169-179.

Olson + Olson Consulting. 2001. Tactics to reduce mountain pine beetle susceptibility. Report to Alberta Sustainable Resource Development.

Packer, J.G. 1974. A Supplement to E.H. Moss's Flora of Alberta. University of Toronto Press, Toronto. 31 pp.

Parendes, L.A., and J.A. Jones. 2000. Role of light availability and dispersal in exotic plant invasion along roads and streams in the H. J. Andrews Experimental Forest, Oregon. Conservation Biology 14: 64-75.

Patterson, D.T., and D.A. Mortensen. 1985. Effects of temperature and photoperiod on common crupina (Crupina vulgaris). Weed Science 33: 333-339.

Pattie, D.L., and R.S. Hoffmann. 1992. Mammals of the North American parks and prairies. D.L. Pattie, Edmonton, AB. 579 pp.

Pearce, C.M., and D.G. Smith. 2003. Saltcedar: distribution, abundance, and dispersal mechanisms, northern Montana, USA. Wetlands 23: 215-228.

Perrault, A., M. Bennett, S. Burgiel, A. Delach, and C. Muffett. 2003. Invasive Species, Agriculture and Trade: Case Studies from the NAFTA Context. Discussion paper for the Second North American Symposium on Assessing the Environmental Effects of Trade (Mexico City, March 25-26, 2003): North American Commission for Environmental Cooperation.

Peschken, D.P., R. DeClerck-Floate, and A.S. McClay. 1997. Cassida azurea Fab. (Coleoptera: Chrysomelidae): host specificity and establishment in Canada as a biological control agent against the weed Silene vulgaris (Moench) Garcke. Canadian Entomologist 129: 949958.

Pimentel, D., L. Lach, R. Zuniga, and D. Morrison. 1999. Environmental and economical costs associated with non-indigenous species in the United States. Cornell University, College of Agriculture and Life Sciences. <http://www.news.cornell.edu/releases/Jan99/species_costs.html > Consulted on

Pimentel, D., L. Lach, R. Zuniga, and D. Morrison. 2000. Environmental and economic costs of nonindigenous species in the United States. Bioscience 50: 53-65.

Plummer, A.P., D.R. Christensen, and S.B. Monsen. 1968. Restoring big-game range in Utah. Ephraim, UT: Utah Division of Fish and Game.

Post, J.R., and F.D. Johnston. 2002. Status of the bull trout (Salvelinus confluentus) in Alberta: Wildlife Status Report No. 39. Edmonton, AB: Alberta Sustainable Resource Development, Alberta Conservation Association.

Proctor, H. 2002. Express News. New Animals Worm into Alberta. University of Alberta. <http://www.expressnews.ualberta.ca/expressnews/articles/ideas.cfm?p_ID=3447\&s= a> Consulted on

Pybus, M. 1999. Development of a generic import protocol for cervids entering Alberta. Hazard Analysis-Helminths: Alberta Risk Assessment and Advisory Committee. 
Pybus, M.J. 1988. Rabies and rabies control in striped skunks (Mephitis mephitis) in three prairie regions of western North America. Joumal of Wildlife Diseases 24: 434-449.

Ratcliffe, S.T., M.E. Gray, and K.L. Steffey. 2002. Alfalfa Weevil Hypera postica Gyllenhal. University of Illinois. <http://www.ipm.uiuc.edu/fieldcrops/insects/alfalfa_weevil/> Consulted on

Richards, C.G.J. 1989. The pest status of rodents in the United Kingdom. pp. 21-33 in Putman, R.J. (Ed.), Mammals as Pests. London: Chapman and Hall.

Richter, B.D., D.P. Braun, M.A. Mendelson, and L.L. Master. 1997. Threats to imperiled freshwater fauna. Conservation Biology 11: 1081-1093.

Ridenour, W.M., and R.M. Callaway. 2001. The relative importance of allelopathy in interference: the effects of an invasive weed on a native bunchgrass. Oecologia 126: 444450.

RNT Consulting. 2002. Environmental and Economic Costs of Alien Invasive Species in Canada. Picton, ON.

Saltonstall, K. 2002. Cryptic invasion by a non-native genotype of the common reed, Phragmites australis, into North America. PNAS 99: 2445-2449.

Samuel, W.M., M.J. Pybus, and A.A. Kocan. 2001. Parasitic diseases of wild mammals. Iowa State Press, Ames, IO. USA. 559 pp.

Scheu, S., and D. Parkinson. 1994. Effects of invasion of an aspen forest (Canada) by Dendrobaena octaedra (Lumbricidae) on plant growth. Ecology 75: 2348-2361.

Schuman, G.E., H.H. Janzen, and J.E. Herrick. 2002. Soil carbon dynamics and potential carbon sequestration by rangelands. Environmental Pollution 116: 391-396.

Sexton, J.P., J.K. McKay, and A. Sala. 2002. Plasticity and genetic diversity may allow saltcedar to invade cold climates in North America. Ecological Applications 12: 1652-1660.

Shiflet, T.N. 1994. Rangeland cover types of the United States. Society for Range Management, Denver, CO. 152 pp.

Simon, K.S., C.R. Townsend, B.J.F.Biggs, W.B. Bowden, and R.D. Frew. 2002. Habitat-specific nitrogen dynamics in streams containing native or invasive fish. University of Otago Freshwater Ecology Group.

<http://telperion.otago.ac.nz/erg/freshwater/documents/simon02.pdf > Consulted on

Sinton-Gerling, H., ed. 2000. Native Plant Revegetation Guidelines for Alberta. Edmonton, AB: Native Plant Working Group, Alberta Agriculture, Food and Rural Development and Alberta Environment. pp.

Smith, B. 2001. Status of the western spiderwort (Tradescantia occidentalis) in Alberta: Alberta Wildlife Status Report No. 31. Edmonton, AB: Alberta Sustainable Resource Development, Alberta Conservation Association.

Smith, B. 2003. Status of the small-flowered sand verbena (Tripterocalyx micranthus) in Alberta: Alberta Wildlife Status Report No. 48. Edmonton, AB: Alberta Sustainable Resource Development, Alberta Conservation Association.

Smith, J.A., R.A. Blanchette, M.E. Ostry, and N.A. Anderson. 2002. Etiology of bronze leaf disease of Populus. Plant Disease 86: 462-469.

Smoliak, S., D. Penney, A.M. Harper, and J.S. Horricks. 1981. Alberta Forage Manual. Alberta Agriculture, Print Media Branch, Edmonton, AB. 87 pp.

Staines, C.L., Jr, M.J. Rothchild, and R.B. Trumble. 1990. A survey of the Coccinellidae (Coleoptera) associated with nursery stock in Maryland. Proceedings of the Entomological Society of Washington 92: 310-313. 
Statistics Canada. 2001. Statistics Canada. <http://www.statcan.ca > Consulted on November 20, 2003.

Stringham, T.K., W.C. Krueger, and P.L. Shaver. 2003. State and transition modeling: an ecological process approach. Journal of Range Management 56: 106-113.

Stubbendieck, J., S.L. Hatch, and C.H. Butterfield. 1992. North American range plants. 4th ed. University of Nebraska Press, Lincoln, NE. 493 pp.

Sutherst, R.W., G.F. Maywald, T. Yonow, and P.M. Stevens. 1999. CLIMEX: Predicting the Effects of Climate on Plants and Animals. CSIRO Publishing, Collingwood, Australia. iv + 88 pp.

Thoen, C.O., and E.M. Himes. 1981. Tuberculosis. pp. 446 in Davis, J.W., L.H. Karstad and D.O. Trainer (Eds.), Infectious Diseases of Wild Mammals. Ames IO, USA: Iowa State Press.

Thomas, A.G., B.L. Frick, and L.M. Hall. 1998. Alberta Weed Survey of Cereal and Oilseed Crops in 1997, Weed Survey Series Publication 98-2. Agriculture and Agri-Food Canada, Saskatoon, Saskatchewan. 241 pp.

Tomback, D.F. 2003. Rapid Decline of Whitebark Pine Communities: Ecological Implications [Web Page]. <http://www.forestry.ubc.ca/alpine/highlights/press-pdfs/07-mountainscience-whitebark-pine-print.pdf> Consulted on November 20, 2003.

Townsend, C.R., K. Simon, T. Crowl, A. Flecker, A. McIntosh, and A. Huryn. 2004. Invasion Biology of Brown Trout. University of Otago Freshwater Ecology Group. <http://telperion.otago.ac.nz/erg/freshwater/research\%20areas/trout/trout.htm> Consulted on January 10, 2004.

Turnock, W.J., I.L. Wise, and F.O. Matheson. 2003. Abundance of some native coccinellines (Coleoptera: Coccinellidae) before and after the appearance of Coccinella septempunctata. Canadian Entomologist 135: 391-404.

U.S. Congress Office of Technology Assessment. 1993. Harmful Non-Indigenous Species in the United States, OTA-F-565. U.S. Government Printing Office, Washington, DC. 391 pp.

United Nations Environment Program. 2002. Guiding principles for the prevention, introduction and mitigation of impacts of alien species that threaten ecosystems, habitats or species. pp. 247-252 in, Report of the Sixth Meeting of the Conference of the Parties to the Convention on Biological Diversity. The Hague.

Urness, P.J. 1983. Value of crested wheatgrass for big game, 1986. pp. 147-153 in Johnson, K.L. (Ed.) Proceedings of the Crested wheatgrass: its values, problems and myths, Logan, UT. Utah State University.

USWBSI. 2003. US Wheat and Barley Scab Initiative. <http://www.scabusa.org/index.html> Consulted on

Van Arsdel, E.P. 1972. Environment in relation to white pine blister rust infection. pp. 479-491 in Bingham, R.F., R.J. Hoff and G.I. McDonald (Eds.), Biology of Rust Resistance in Forest Trees: Misc. Publ. No. 1221: USDA Forest Service.

van Ruijven, J., G.B. De Deyn, and F. Berendse. 2003. Diversity reduces invasibility in experimental plant communities: the role of plant species. Ecology Letters 6: 910-918.

VanDyk, J. 1996. European Corn Borer home page. Iowa State University. <http://www.ent.iastate.edu/pest/cornborer/intro/intro.html > Consulted on

Vujnovic, K., R.W. Wein, and M.R.T. Dale. 2000. Factors determining the centrifugal organization of remnant Festuca grassland communities in Alberta. Journal of Vegetation Science 11: 127-134.

Wasser, C.H. 1982. Ecology and culture of selected species useful in revegetating disturbed lands in the West. FWS/OBS-82/56. U.S. Department of the Interior, Fish and Wildlife Service, Office of Biological Services, Western Energy and Land Use Team, Washington, DC. 347 pp. 
Weaver, T., J. Lichthart, and D. Gustafson. 1990. Exotic invasion of timberline vegetation, Northern Rocky Mountains, USA. pp. 208-213 in Schmidt, W.C. and K.J. McDonald (Eds.) Proceedings of the Symposium on whitebark pine ecosystems: ecology and management of a high-mountain resource; Gen. Tech. Rep. INT-270, March 29-31, 1989, Bozeman, MT. Ogden, UT: USDA Forest Service, Intermountain Research Station.

Weber, W.J. 1979. Health hazards from Pigeons, Starlings and English Sparrows. Thompson Publications, Fresno, CA, USA. 138 pp.

Weeden, C.R., A.M. Shelton, Y. Li, and M.P. Hoffmann. 2003. Biological control: a guide to natural enemies in North America. Cornell University. <http://www.nysaes.cornell.edu/ent/biocontrol/> Consulted on

Wein, R.W., G. Wein, S. Bahret, and W.J. Cody. 1992. Northward invading non-native vascular plant species in and adjacent to Wood Buffalo National Park, Canada. Canadian Field Naturalist 106: 216-224.

Welk, E., K. Schubert, and M.H. Hoffmann. 2002. Present and potential distribution of invasive garlic mustard (Alliaria petiolata) in North America. Diversity \& Distributions 8: 219-233

Westbrooks, R.G. 1998. Invasive Plants: Changing the Landscape of America. Federal Interagency Committee for the Management of Noxious and Exotic Weeds, Washington, DC. 109 pp.

Wheatly, W., and M. Wheatly. 2004. Exploring changes in native ladybirds before and after establishment of Coccinella septempunctata using 100 years worth of specimen collections. Unpublished manuscript.

Whirling Disease Foundation. 2001. <http://www.whirling-disease.org/> Consulted on

White, D.J. 1997. Tanacetum vulgare L.: Weed potential, biology, responses to herbivory, and prospects for classical biological control in Alberta. M.Sc., Department of Entomology, University of Alberta, Edmonton, Alberta.

White, D.J., E. Haber, and C. Keddy. 1993. Invasive Plants of Natural Habitats in Canada: An Integrated Review of Wetland and Upland Species and Legislation Governing their Control Canadian Wildlife Service, Environment Canada, Ottawa, ON. 121 pp.

Wilcove, D.S., D. Rothstein, J. Dubow, A. Phillips, and E. Losos. 1998. Quantifying threats to imperiled species in the United States. Bioscience 48: 607-615.

Williamson, M., and K.C. Brown. 1986. The analysis and modelling of British invasions. Philosophical Transactions of the Royal Society B 314: 505-522.

Williamson, M., and A. Fitter. 1996. The varying success of invaders. Ecology 77: 1661-1666.

Willoughby, M.G., and M.J. Alexander. 2000. A range condition dilemma. Rangelands 22: 23-26.

Willoughby, M.G., M.J. Alexander, and B.W. Adams. 2003. Range plant community types and carrying capacity for the Montane Subregion. Pub. no. T/033. Edmonton, AB: Sustainable Resource Development. Public Lands Division.

Wilson, E.O. 1992. The Diversity of Life. Belknap Press, Cambridge, MA, USA. 424 pp.

Wilson, S.D. 1989. The suppression of native prairie by alien species introduced for revegetation. Landscape and Urban Planning 17: 113-119.

Witter, F.G: 1981. Brucellosis. pp. 446 in Davis, J.W., L.H. Karstad and D.O. Trainer (Eds.), Infectious Diseases of Wild Mammals. Ames IO, USA: Iowa State Press.

Woo, S.L., A.G. Thomas, D.P. Peschken, G.G. Bowes, D.W. Douglas, V.W. Harms, and A.S. McClay. 1991. The biology of Canadian weeds. 99. Matricaria perforata Mérat (Asteraceae). Canadian Journal of Plant Science 71: 1101-1119.

Yde-Andersen, A. 1979. Host spectrum, host morphology and geographic distribution of larch canker, Lachnellula willkommii. A literature review. European Journal of Forest Pathology 9 : 211-219. 
Young, B. 2001. Grass seed production in Canada. Oregon State University Extension Service Crop and Soil News/Notes 15(1): 6-7.

Zavaletta, E. 2000. Valuing ecosystem services lost to Tamarix invasion in the United States. pp. 262-300 in Mooney, H.A. and R.J. Hobbs (Eds.), Invasive Species in A Changing World. Washington, DC: Island Press.

Ziller, W.G. 1974. The Tree Rusts of Western Canada. Publication no. 1329. Canadian Forestry Service, Victoria, B.C. viii, 272 pp. 


\section{LISTING OF DATABASES}

Major websites and databases with information relevant to invasive species in Alberta

\section{Canadian websites and databases}

Canadian Wildlife Federation Invasive Species Database

http://www.cwf-

fcf.org/pages/wildprograms/wildprogramsnwweb e.asp?section=6\&language=e

Can be searched by taxonomic groups, keywords or species names. Brief summaries for each species of taxonomy, native range, invasive range, time of invasion, invasion pathway, status, impacts, and control measures.

World Wildlife Fund Canada Invasive Species database An Access database developed by WWF Canada as part of their Nature Audit Initiative. Lists 158 invasive species including vascular plants, diseases, vertebrates, insects, crustaceans, molluscs, etc. Includes notes on distribution, habitat, impacts, date of introduction, and expected changes in abundance. Not available online but a copy was kindly provided for our use by WWF Canada. Requests concerning this database should be directed to Lindsay Roger, Senior Manager, Wildlife Conservation and Outreach, WWF Canada.

Canadian Botanical Conservation Network: Invasive Plants of Canada http://www.rbg.ca/cbcn/en/invasives/invade1.html Overview of invasive plant issues and impacts in Canada, with lists of invasive plant species and brief notes on status, distribution, and invasive potential.

Invasive Plants of Natural Habitats in Canada - CWS http://www.cws-scf.ec.gc.ca/publications/inv/index_e.cfm Online text of "Invasive plants of natural habitats in Canada: an integrated review of wetland and upland species and legislation governing their control" (White et al. 1993). This includes both a review of invasive plants of upland and wetland habitats and an evaluation of federal and provincial legislation dealing with noxious weeds and their potential use in controlling the spread of plants invasive in natural habitats.

Canadian Food Inspection Agency list of pests and possible threats http://www.inspection.gc.ca/english/sci/surv/pesrave.shtml

Canadian Forest Service Maritime Forestry Centre Report on national forest defoliation including specific reference to Mountain Pine Beetle http://www.lib.unb.ca/Texts/Forest/MX206/English/contents.html

Sustainable Resource Development Forest Health Invasive Species List http://www3.gov.ab.ca/srd/forests/health/e_examples.html

$\underline{\text { US and North American websites and databases }}$

Nature Conservancy Wildland Invasive Species Team Page 
http://tncweeds.ucdavis.edu/esadocs.html

Links to all available " Element Stewardship Abstracts" which are detailed species-by-species accounts covering distribution, habitat, impacts, biology, management, and research needs, with extensive references to original sources. ESAs are currently online for over 100 invasive plant species.

Invasive Species: The Nation's Invasive Species Information System http://www.Invasivespecies.gov

Gateway to Federal efforts concerning invasive species. On this site you can learn about the impacts of invasive species and the Federal government's response, as well as read select species profiles and find links to agencies and organizations dealing with invasive species issues. Invasivespecies.gov is also the website for the National Invasive Species Council, which coordinates Federal responses to the problem.

\section{The INVADERS Database}

http://invader.dbs.umt.edu

A comprehensive database of exotic plant names and weed distribution records for five states in the northwestern United States. The spatial and temporal spread of weeds can be displayed using the historic distribution records in INVADERS. The INVADERS web site contains actual examples of how land management and weed regulatory agencies are using these data to improve their weed management programs. Noxious weed listings are provided for all US states and six southern tier Canadian provinces.

Nonindigenous Aquatic Species

http://nas.er.usgs.gov/

Information resource for the United States Geological Survey. Located at the Center for Aquatic Resource Studies, this site has been established as a central repository for accurate and spatially referenced biogeographic accounts of nonindigenous aquatic species, including vertebrates, invertebrates, and plants. Provided are scientific reports, online/real-time queries, spatial data sets, regional contact lists, and general information. The data is made available for use by biologists, interagency groups, and the general public. The geographical coverage is the United States.

National Aquatic Nuisance Species Clearinghouse http://www.cce.cornell.edu/programs/nansc/nan_ld.cfm

An international library of research, public policy, and outreach education publications pertaining to invasive marine and fresh-water aquatic nuisance species in North America. Searchable literature database. Heavy focus on zebra mussels and Great Lakes issues.

North American Non-Indigenous Arthropod Database

http://www.invasivespecies.org/NANIAD.html

The NANIAD presently contains the data so far captured from diverse resources for 2,273 species of non-indigenous insects and arachnids on species name and classification, natural distribution, immigrant distribution, economic and/or environmental impacts, disease vectors, establishment status, years of eradication, location and date of first entry, location and date of re-entries, type and pathway of entry, habitat, host, life history and ecology, and literature citations. Currently not accessible online due to updating. 
Synthesis of the North American Flora

http://www.bonap.org/synth.html

(Kartesz, J.T. 1999. A Synonymized Checklist and Atlas with Biological Attributes for the Vascular Flora of the United States, Canada, and Greenland in Kartesz, J.T. and C.A. Meacham (Eds.), Synthesis of the North American Flora, Version 1.0. Chapel Hill, NC: North Carolina Botanical Garden.)

Distributed on CD-ROM by the North Carolina Botanical Garden.

Comprehensive source for nomenclature and taxonomy for all known native and naturalized vascular plants of North America (USA and Canada) and their associated synonyms. Searchable database contains fully populated summaries for 174 biological fields (e.g. rarity and endemism, nativity, weediness, habit, habitat, etc.) as well as distribution data for all accepted taxa. Synonymized checklists can be displayed and printed for any plant group.

USDA APHIS Pest Risk Assessment Guidelines

http://www.aphis.usda.gov/ppq/weeds/weedsrisk99.html

\section{International websites and databases}

Global Invasive Species Programme

http://www.gisp.org/

The Global Invasive Species Programme was established in 1997 to address global threats caused by Invasive Alien Species (IAS), and to provide support to the implementation of Article $8(\mathrm{~h})$ of the Convention on Biological Diversity, the CBD. The website is part of the Clearing House Mechanism for all IAS related information that relates to the Convention on Biological Diversity. Links to publications, databases, newsletters, case studies, meetings, etc.

Global Invasive Species Database

http://issg.appfa.auckland.ac.nz/database/welcome/

Developed by the IUCN/SSC Invasive Species Specialist Group (ISSG) to provide global information on invasive alien species to agencies, resource managers, decision-makers, and interested individuals. The database focuses on invasive species that threaten biodiversity and covers all taxonomic groups from micro-organisms to animals and plants. Very limited information on Canada at present.

Invasive Species Specialist Group

http://www.issg.org

The Invasive Species Specialist Group (ISSG) is part of the Species Survival Commission (SSC) of The World Conservation Union (IUCN). The ISSG is a global group of 146 scientific and policy experts on invasive species from 41 countries. ISSG provides advice on threats from invasives and control or eradication methods to IUCN members, conservation practitioners, and policy-makers. The group's activities focus primarily on invasive species that cause biodiversity loss, with particular attention to those that threaten oceanic islands.

Aliens-L archives

http://indaba.iucn.org/archives/aliens-1/index.htm 
Archives of Aliens-L, a listserver sponsored by the ISSG and dedicated to alien invasive species, with a focus on those that threaten biodiversity.

FAO Database on Introductions of Aquatic Species (DIAS) http://www.fao.org/WAICENT/FAOINFO/FISHERY/statist/fisoft/dias/mainpage.htm Initially considered primarily only freshwater species of fish, later expanded to include additional taxa, such as molluscs and crustaceans, and marine species. In the mid 1990's a questionnaire was sent to national experts to gather additional information on introductions and transfers of aquatic species in their countries. The database, which contains now about 3,150 records, can be queried through the Search Form. Contains many records for introductions into Canada. Last updated October 1998.

Fishbase

http://www.fishbase.org/search.cfm

A global information system with all you ever wanted to know about fishes. FishBase is a relational database with information to cater to different professionals such as research scientists, fisheries managers, zoologists and many more. Can be searched to obtain lists of introduced fish species by country with links to information on distribution, habitat, biology, pest status, etc. 
Table 1. Occurrences of invasive plant species in the Green Zone of Alberta from inventories by ASRD staff, 1998 - 2003.

\begin{tabular}{|c|c|}
\hline Plant species & Total occurrences \\
\hline Scentless chamomile & 1429 \\
\hline Canada thistle & 969 \\
\hline Tall buttercup & 685 \\
\hline Perennial sow-thistle & 561 \\
\hline Oxeye daisy & 476 \\
\hline Common tansy & 269 \\
\hline Yellow toadflax & 175 \\
\hline Blueweed & 114 \\
\hline Houndstongue & 84 \\
\hline Narrow-leafed hawksbeard & 59 \\
\hline Common mullein & 50 \\
\hline Wild caraway & 34 \\
\hline Field scabious & 21 \\
\hline Stork's bill & 20 \\
\hline Leafy spurge & 15 \\
\hline Bladder campion & 13 \\
\hline Yarrow & 10 \\
\hline Toadflax & 9 \\
\hline Cleavers & 6 \\
\hline Bluebur & 5 \\
\hline Bull thistle & 5 \\
\hline Knapweed & 5 \\
\hline Spotted knapweed & 5 \\
\hline Common burdock & 4 \\
\hline Dalmatian toadflax & 4 \\
\hline Purple loosestrife & 4 \\
\hline Burdock & 3 \\
\hline Foxtail & 3 \\
\hline Henbane & 3 \\
\hline Nodding thistle & 3 \\
\hline White cockle & 3 \\
\hline Cypress spurge & 2 \\
\hline Grassy weeds & 1 \\
\hline Hoary cress & 1 \\
\hline Larkspur & 1 \\
\hline Orange hawkweed & 1 \\
\hline Poplar seedling & 1 \\
\hline Prostrate Knotweed & 1 \\
\hline Sweet clover & 1 \\
\hline None & 339 \\
\hline
\end{tabular}


Table 2. Sources and carriers of entomology quarantine interceptions by CFIA on international imports into Alberta, totals 1997 - 2000.

\begin{tabular}{lc}
\hline \multicolumn{1}{c}{ Source } & Numbers of interceptions \\
\hline U.S.A.(Florida) & 10 \\
India & 9 \\
U.S.A.(California) & 6 \\
U.S.A. (Others) & 5 \\
China & 4 \\
Others/ unknown & 12 \\
Total & 46 \\
& \\
\hline \multicolumn{1}{c}{ Carrier } & Numbers of interceptions \\
\hline Tropical plants & 14 \\
Other plants & 12 \\
Wood, wooden crates & 12 \\
Woollen carpets & 3 \\
Others/ unknown & 5 \\
Total & 46 \\
\hline
\end{tabular}




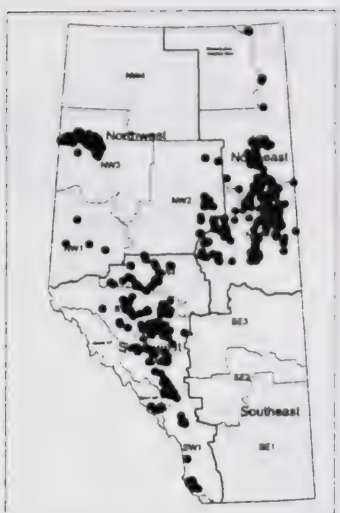

Scentless chamomile

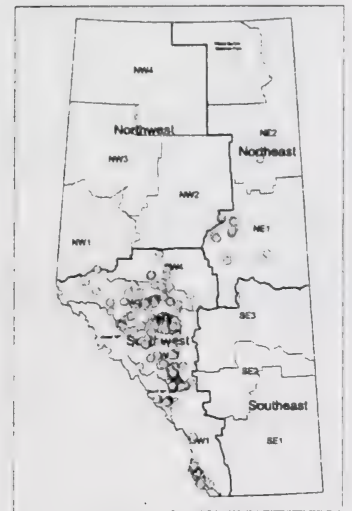

Tall buttercup

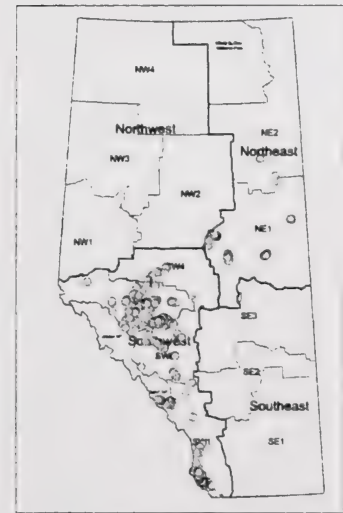

Oxeye daisy

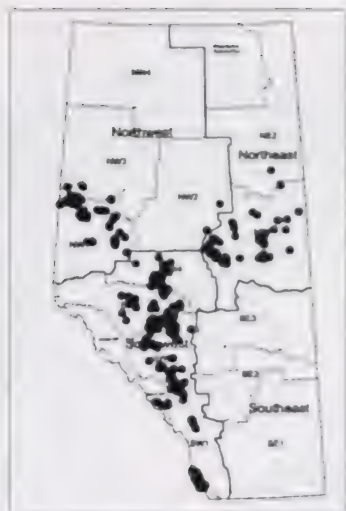

Canada thistle

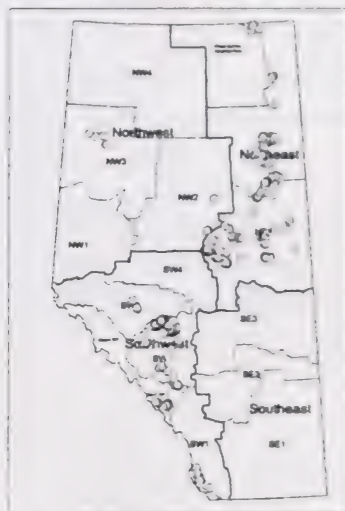

Perennial sow-thistle

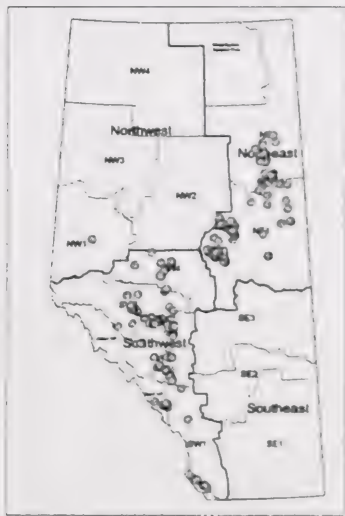

Common tansy

Figure 1. Distribution of some invasive plant species in the Green Zone of Alberta, from inventories by ASRD staff, 1998 - 2003. 


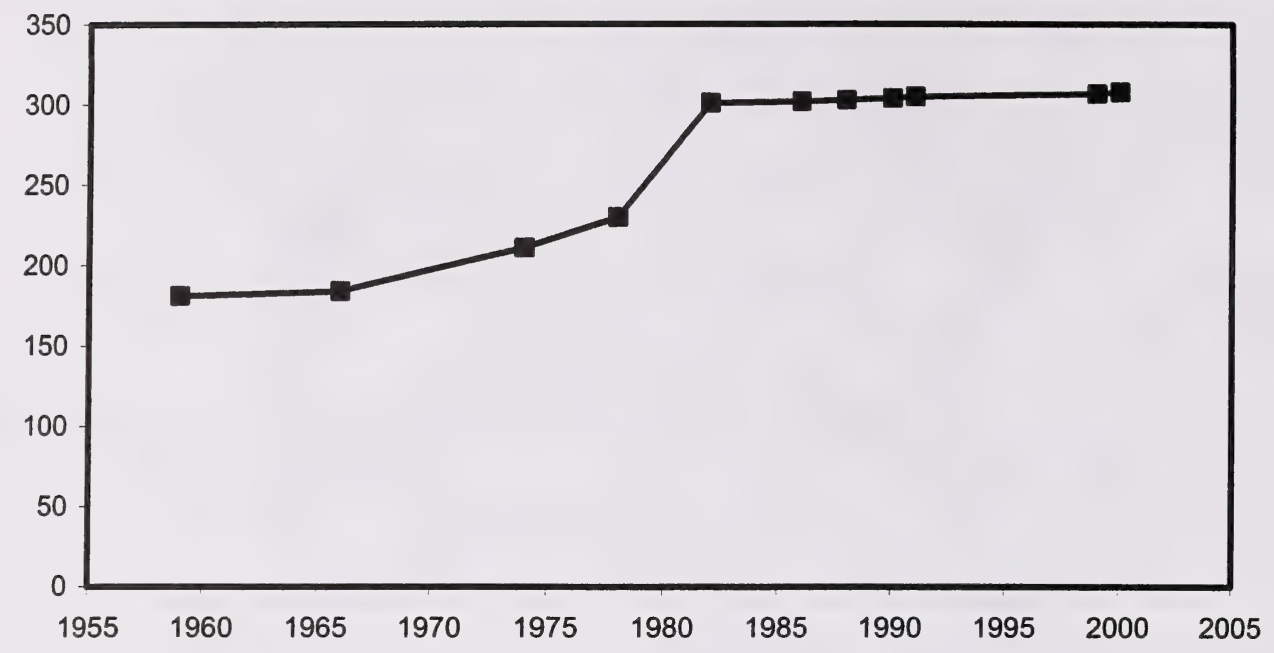

Figure 2. Cumulative number of introduced vascular plant species recorded in Alberta, 1959 to present. 


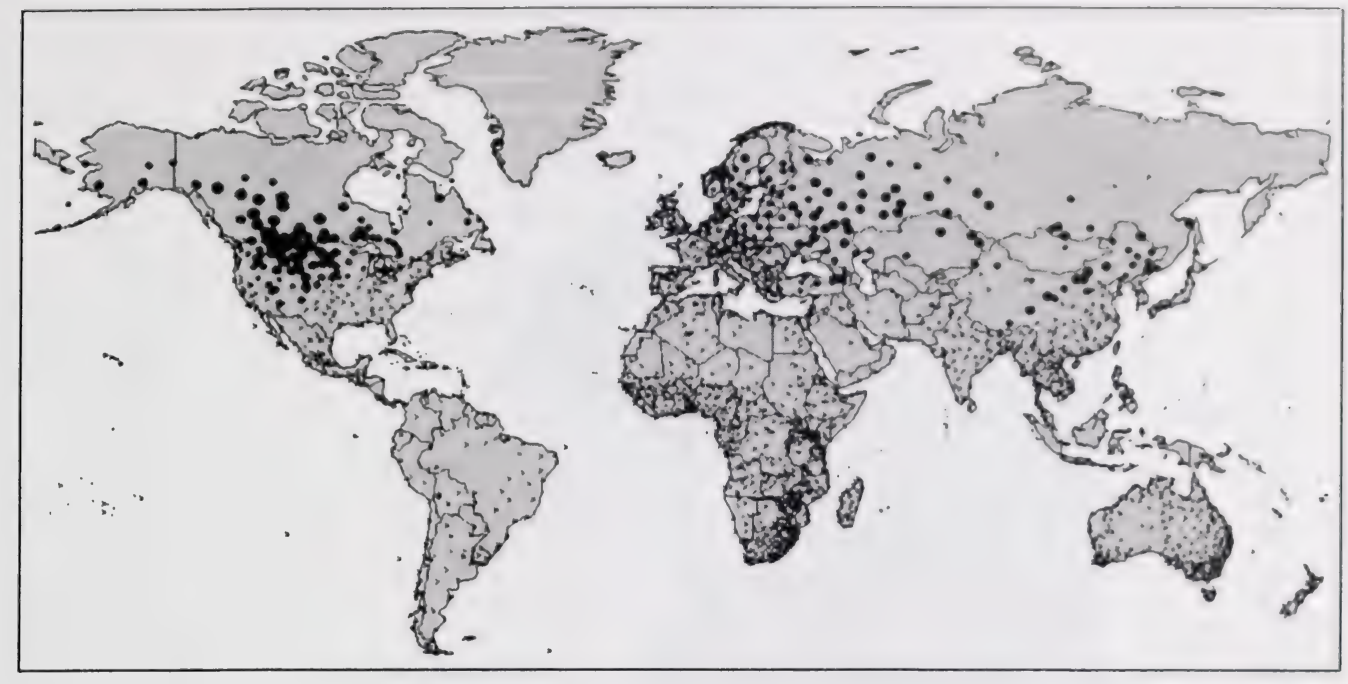

Figure 3. World distribution of climatic matches with five selected locations in Alberta. Locations marked with $\times$ show a match of less than $50 \%$ with any area of Alberta. Size of red circles shows degree of climatic match with Alberta in the range $50-100 \%$. 


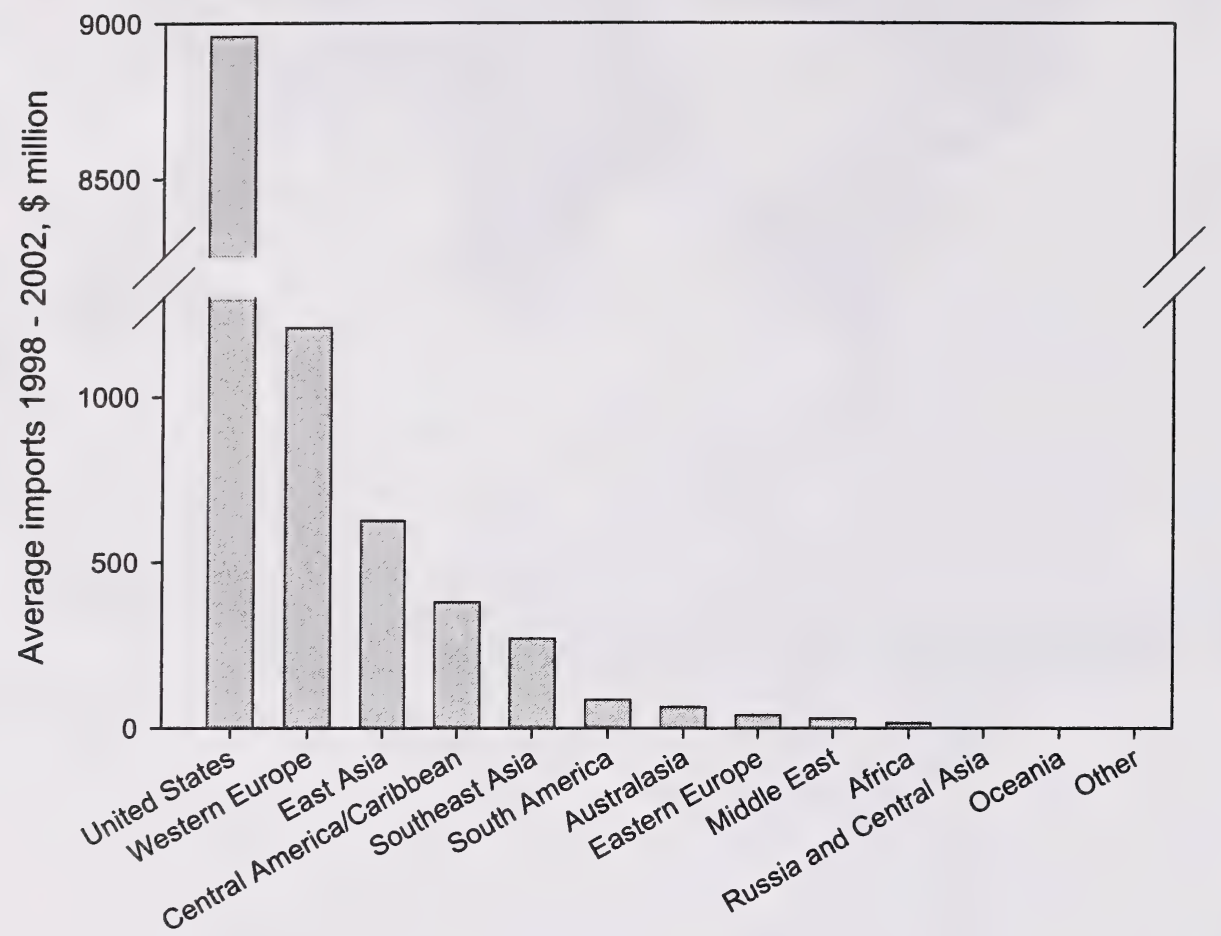

Figure 4. Imports into Alberta from various regions of the world, average for 1998 - 2002 from Industry Canada statistics.

Region definitions: East Asia includes China, Japan, Korea; Central America/Caribbean includes Mexico; Southeast Asia includes Pakistan to Philippines and Indonesia; Australasia includes Australia and New Zealand; Oceania includes Pacific island nations. 


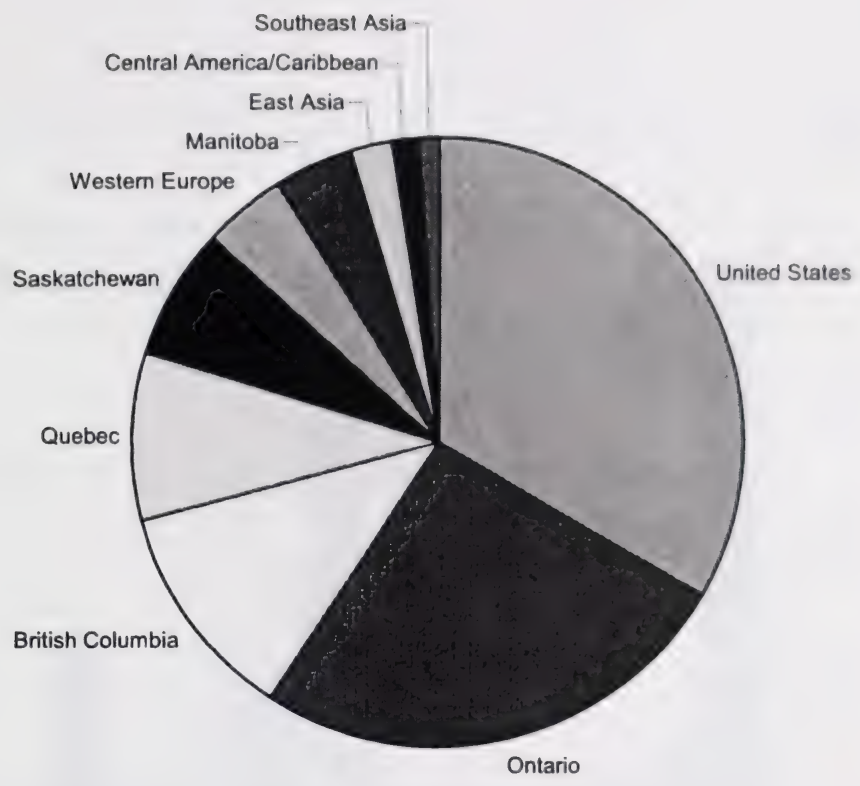

Figure 5. Relative volumes of imports to Alberta from sources inside and outside Canada. Sources (BC Statistics 2000; Industry Canada 2003). 


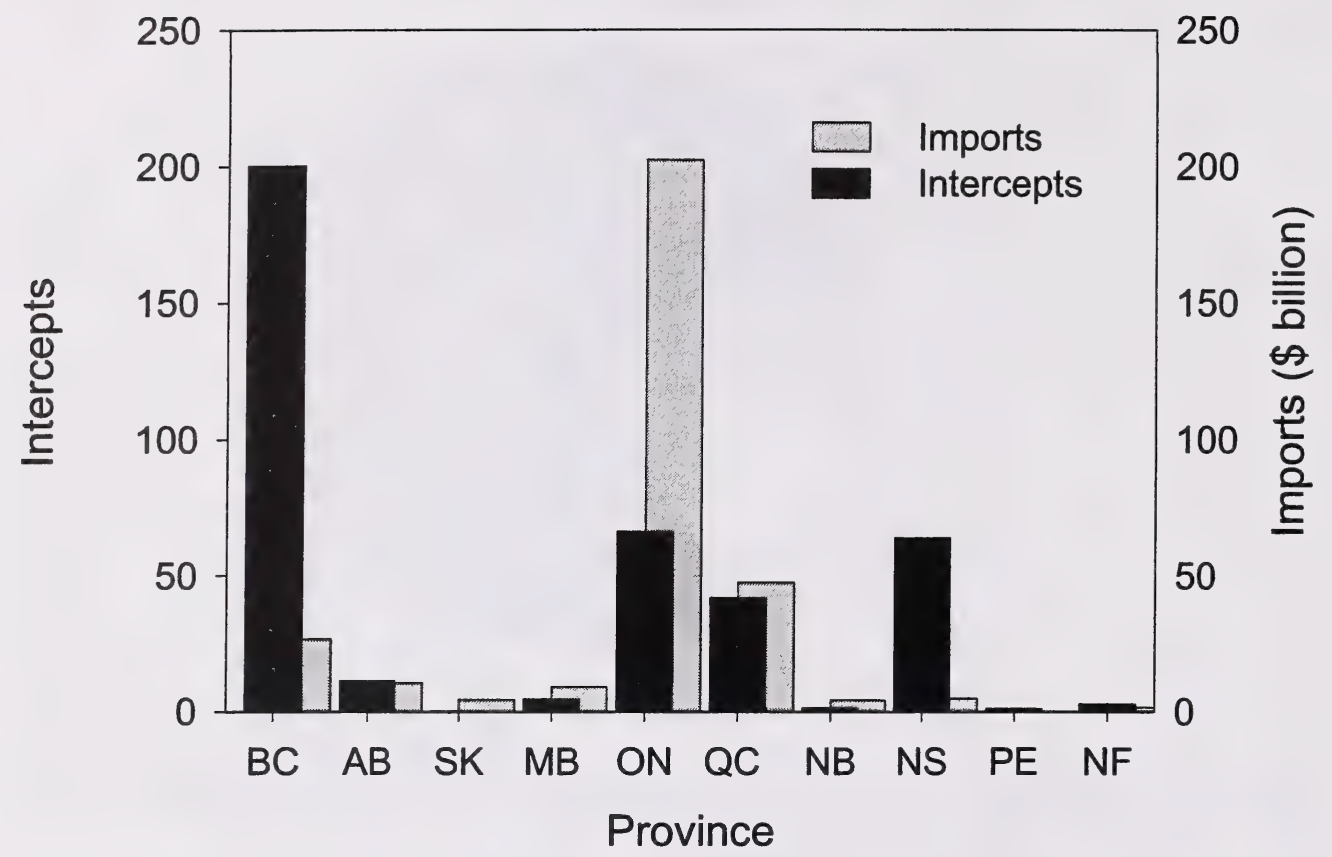

Figure 6. Entomology quarantine interceptions (also including Diplopoda and Mollusca) by Canadian Food Inspection Agency by province.

Mean annual numbers per year for the period 1997-2000, compared with mean annual import volumes to that province from outside Canada for the same period (Canadian Food Inspection Agency 2002a; Industry Canada 2003). 
APPENDIX 1: DETAILED INVASIVE SPECIES LISTINGS 


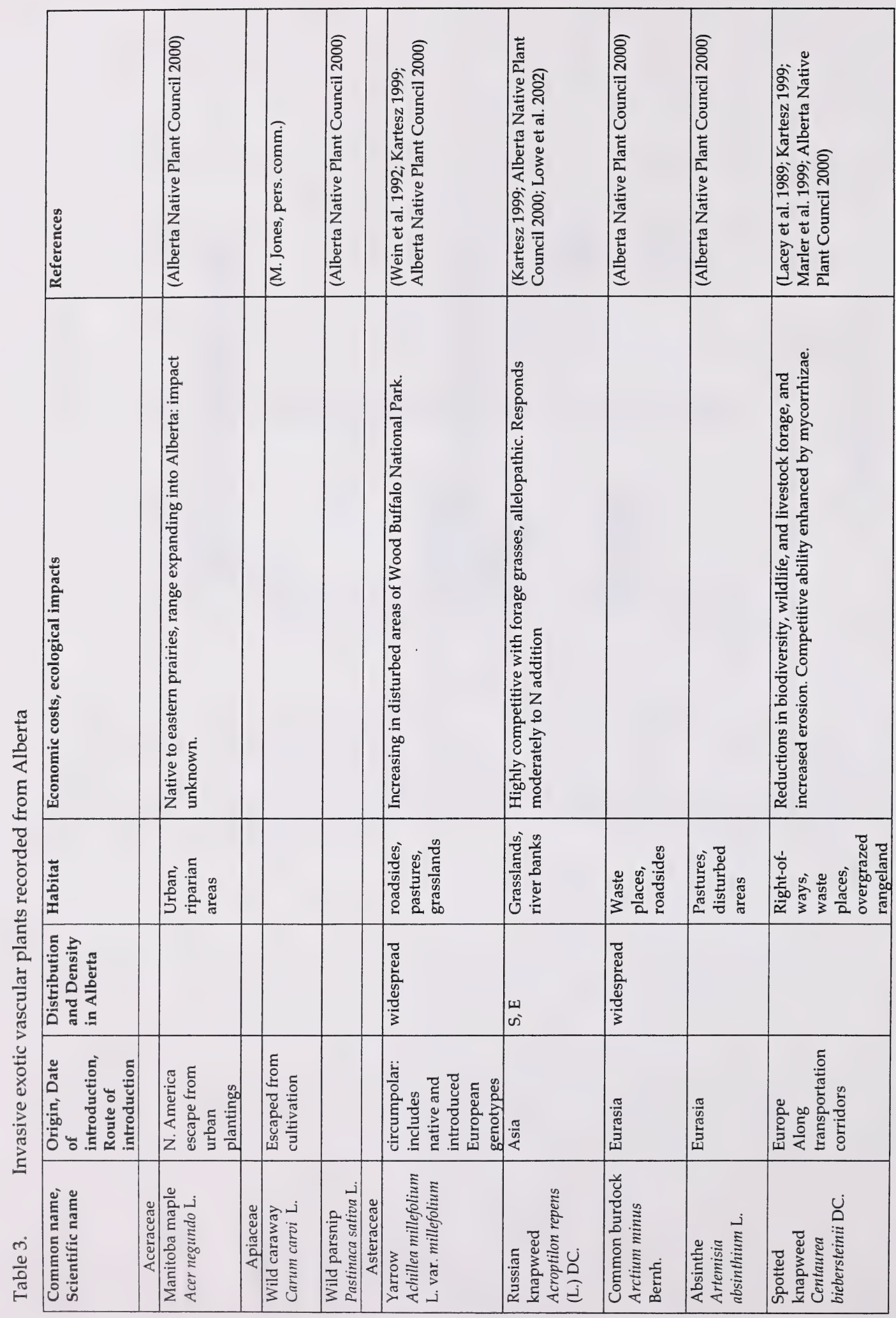




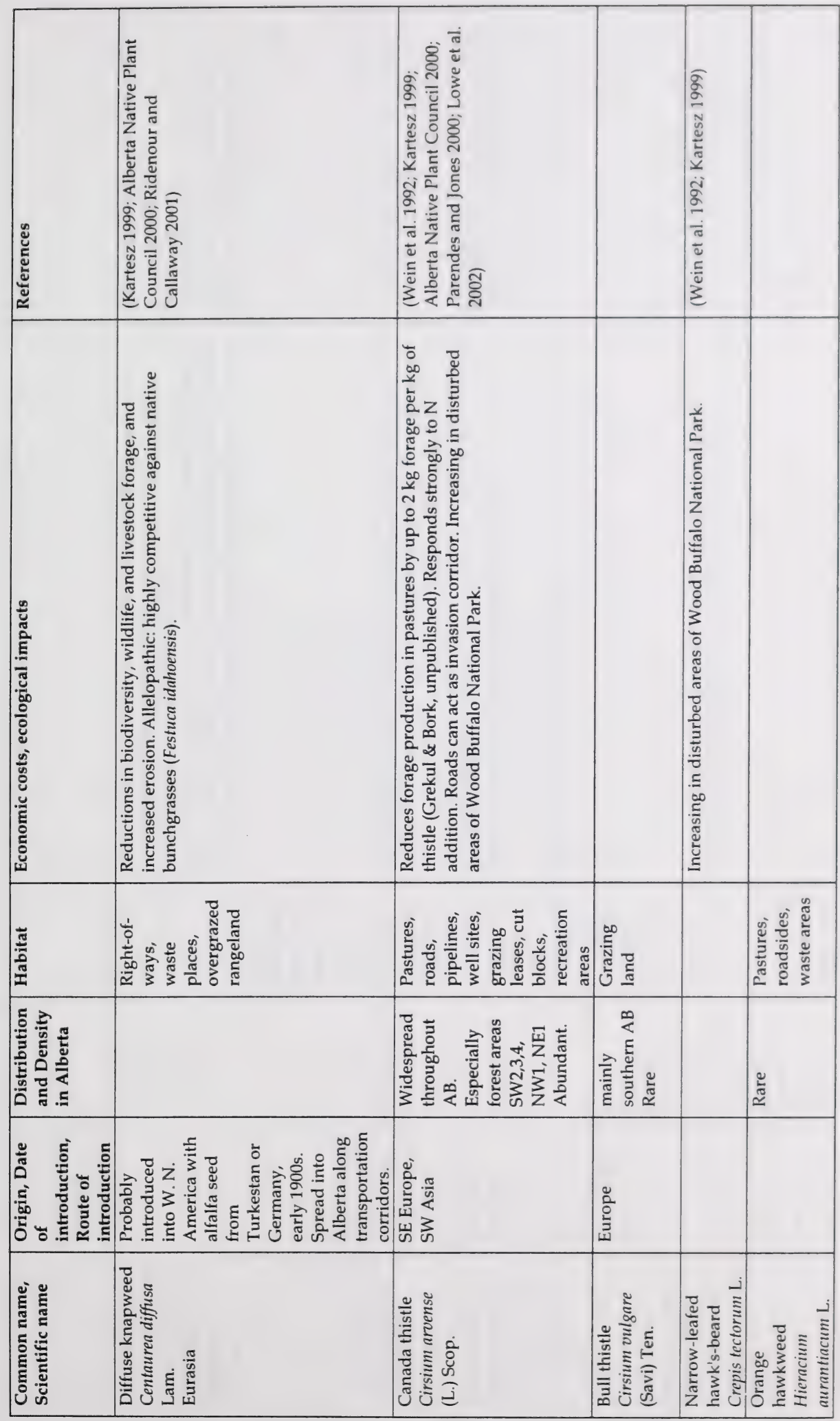




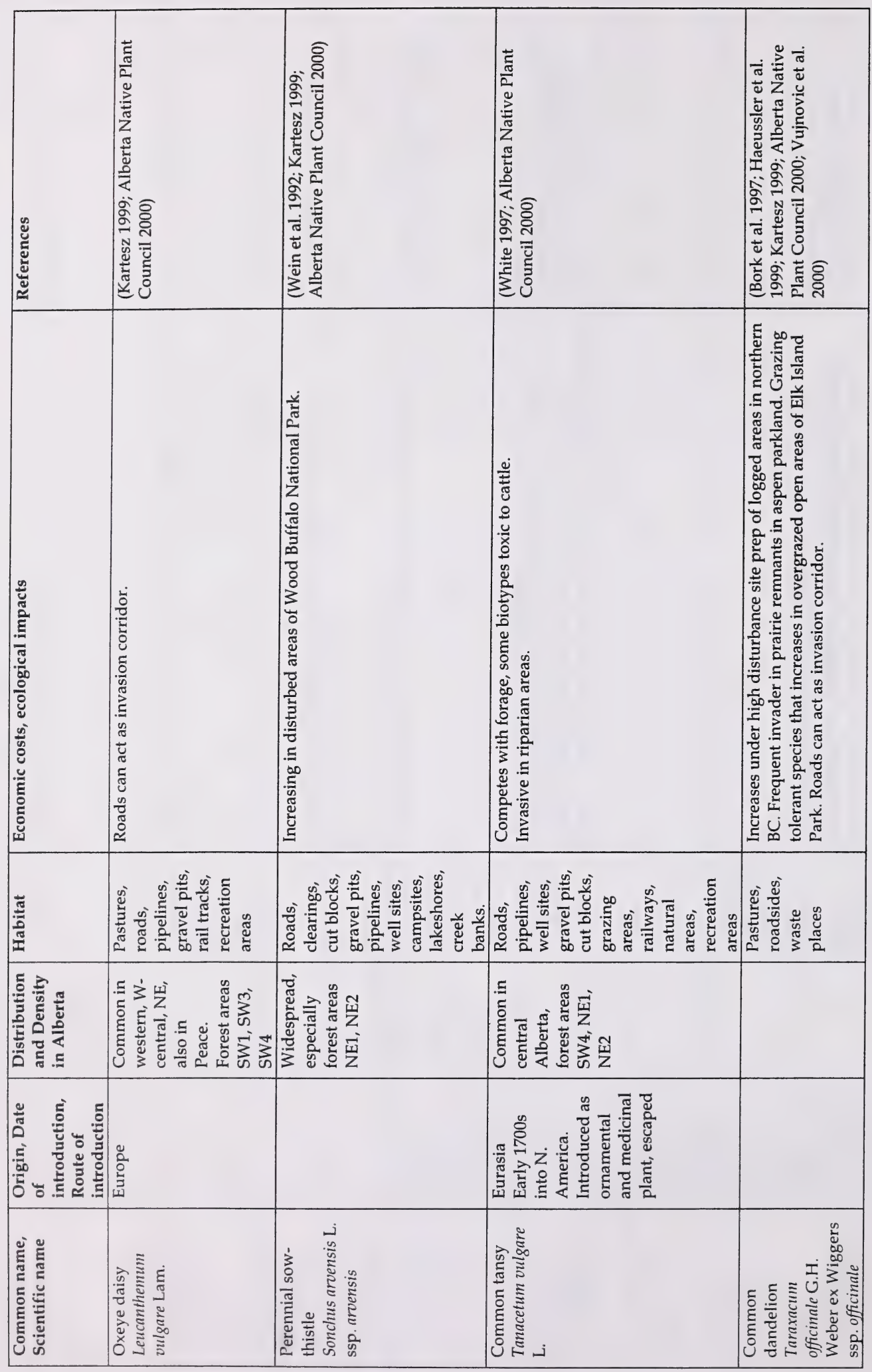




\begin{tabular}{|c|c|c|c|c|c|c|}
\hline 遌 & 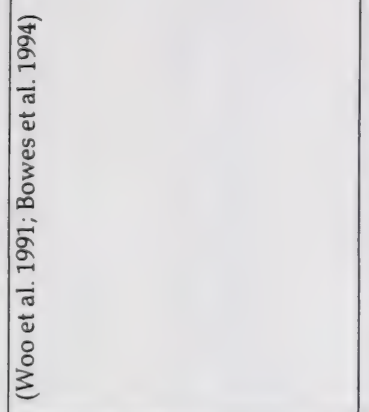 & 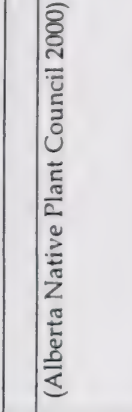 & 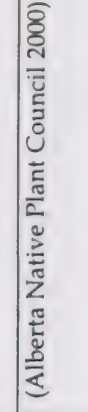 & & 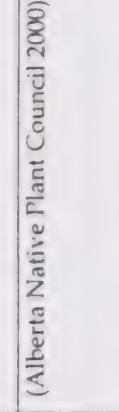 & 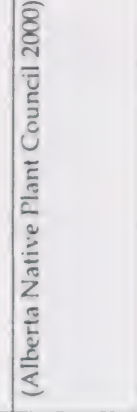 \\
\hline 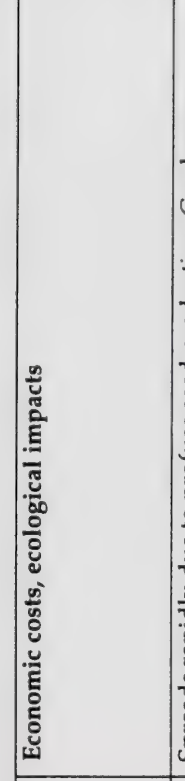 & 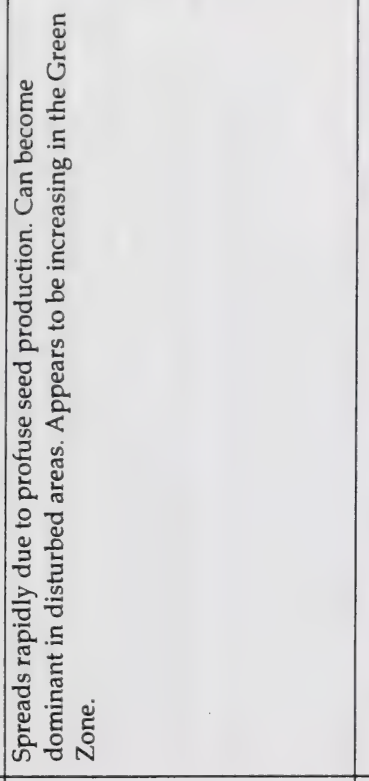 & 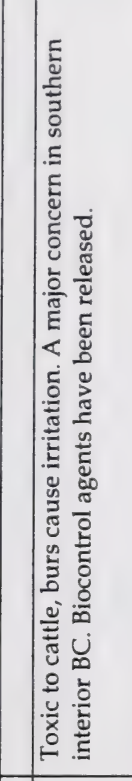 & 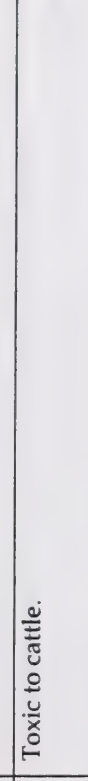 & 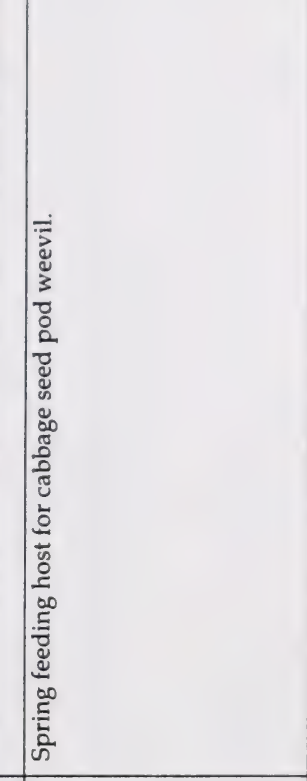 & & \\
\hline 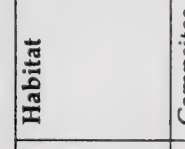 & 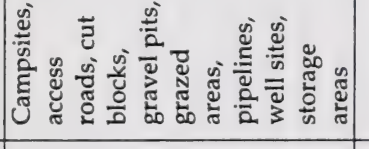 & 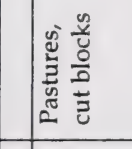 & & 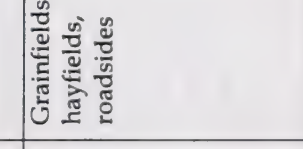 & & 酸 \\
\hline 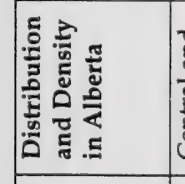 & 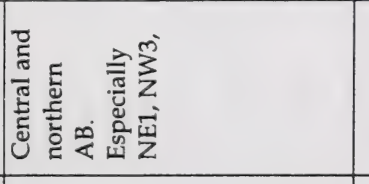 & 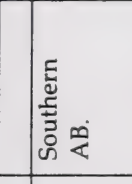 & 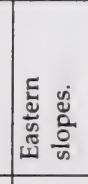 & 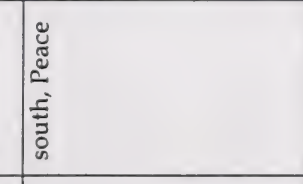 & & 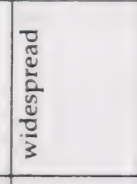 \\
\hline 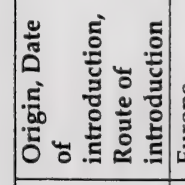 & & 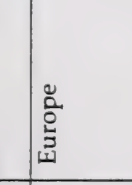 & 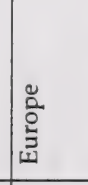 & 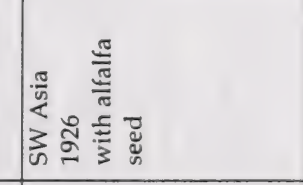 & 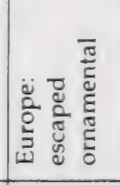 & 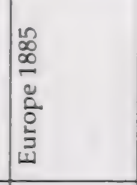 \\
\hline 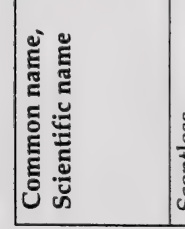 & 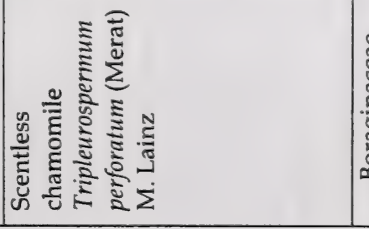 & 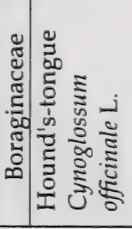 & 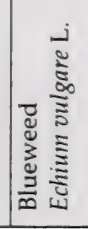 & 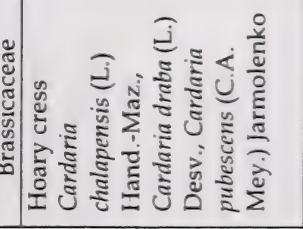 & 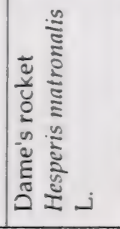 & 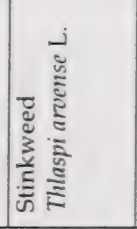 \\
\hline
\end{tabular}




\begin{tabular}{|c|c|c|c|c|c|c|c|}
\hline & 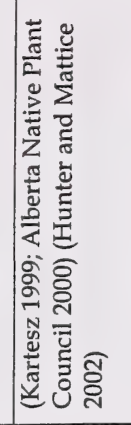 & 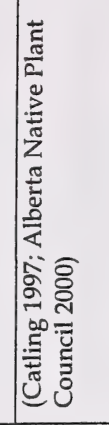 & 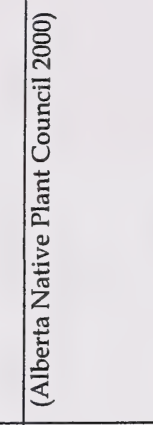 & 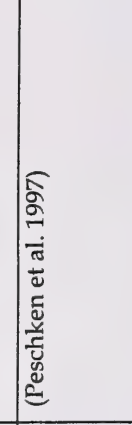 & 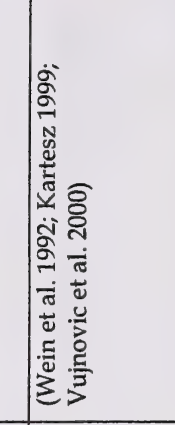 & 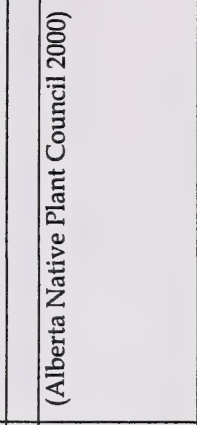 & 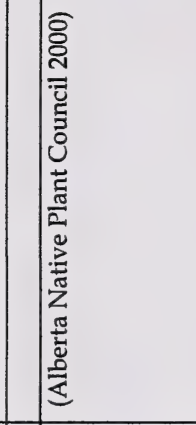 \\
\hline & 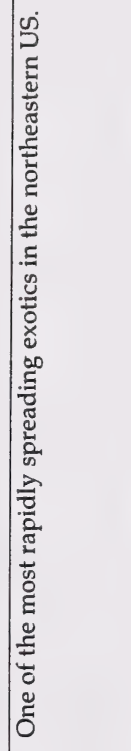 & & & & 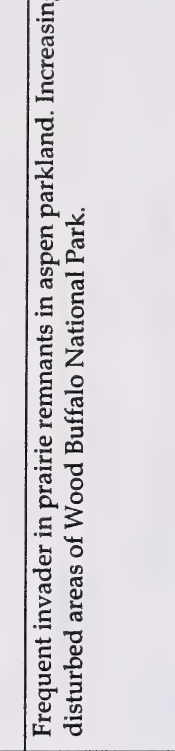 & & 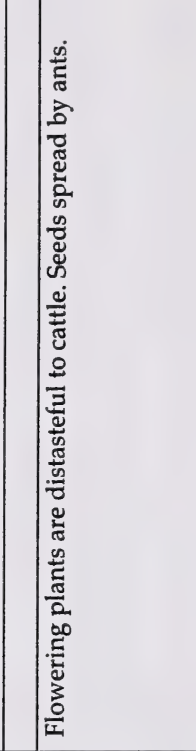 \\
\hline 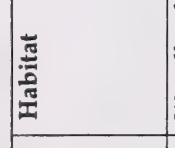 & 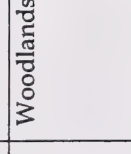 & & 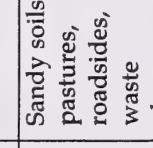 & & 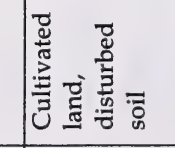 & 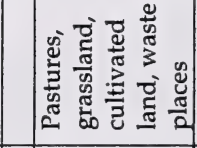 & 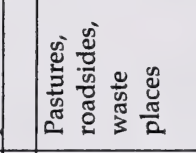 \\
\hline 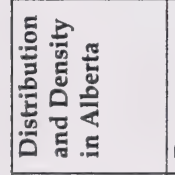 & 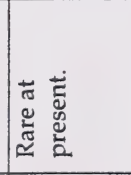 & 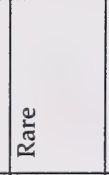 & 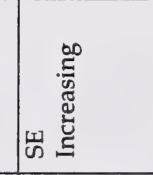 & 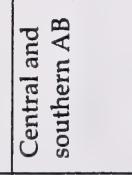 & & 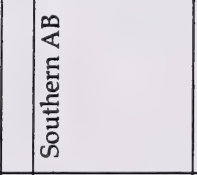 & 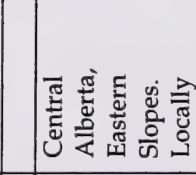 \\
\hline 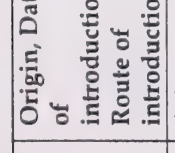 & & & 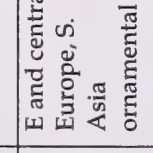 & 言 & & 总 & 颜 \\
\hline 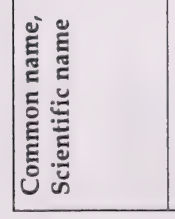 & 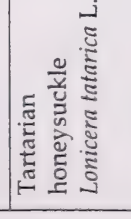 & 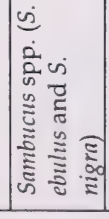 & 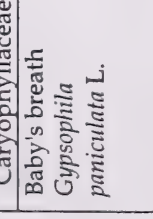 & 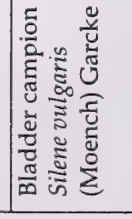 & 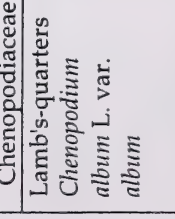 & 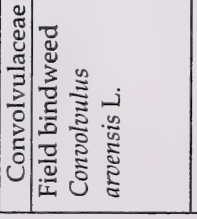 & 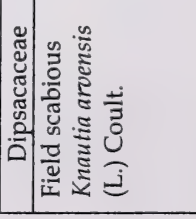 \\
\hline
\end{tabular}




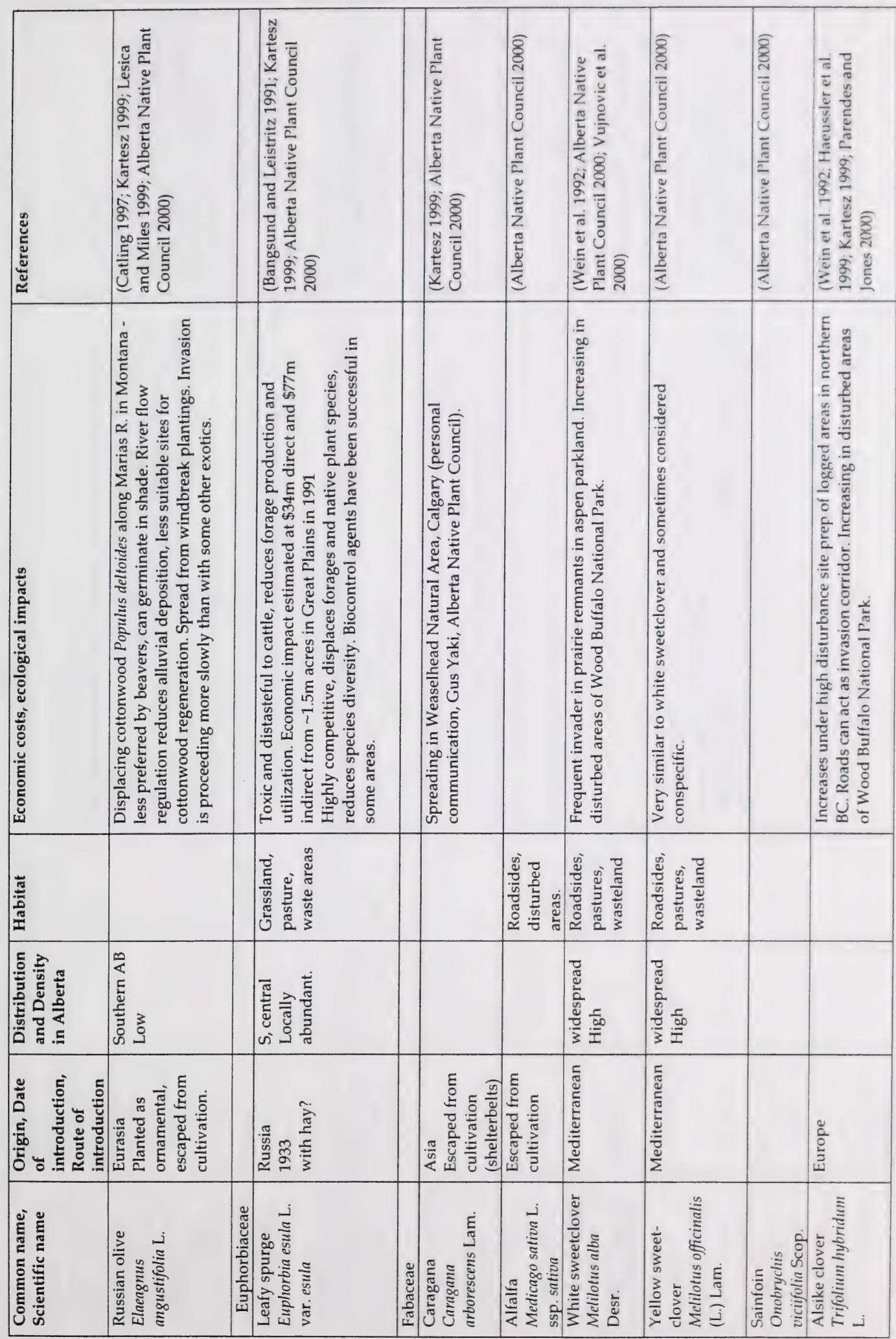




\begin{tabular}{|c|c|c|c|c|c|c|c|c|c|c|}
\hline 总 & 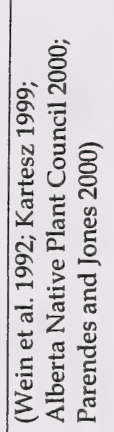 & 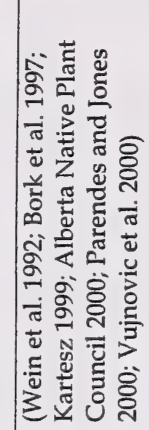 & & & & & 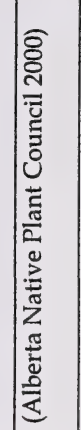 & 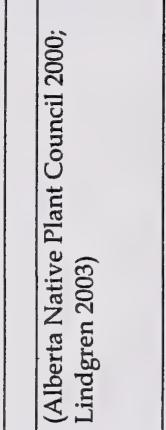 & 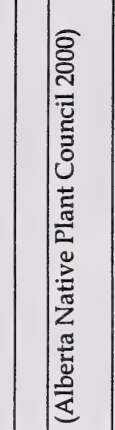 & 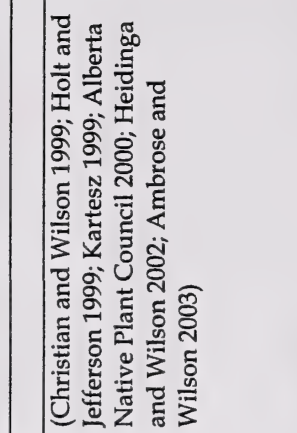 \\
\hline 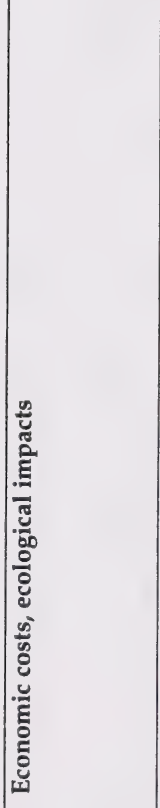 & 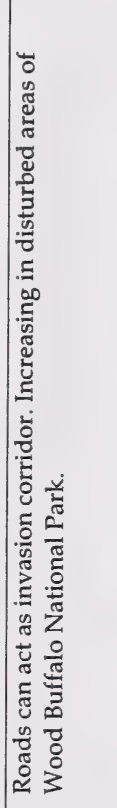 & 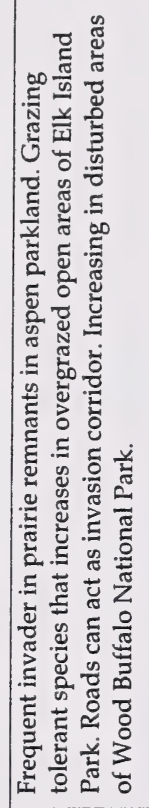 & & & & & & 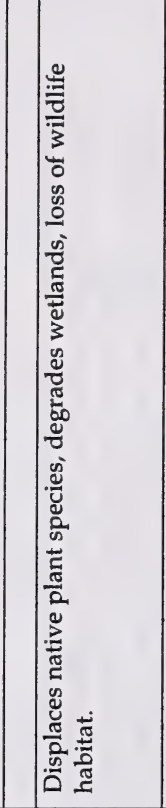 & & 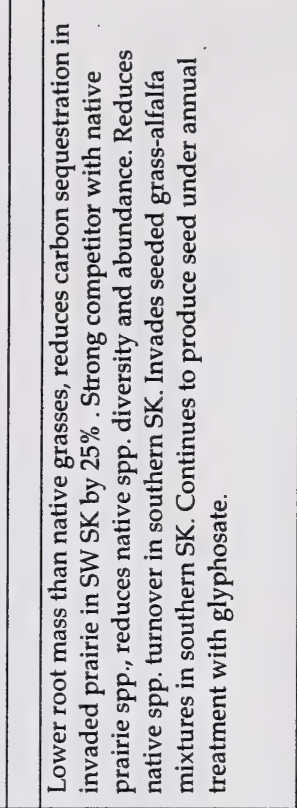 \\
\hline 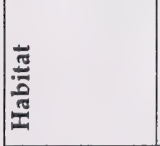 & & & & 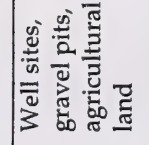 & & & & 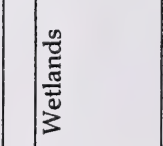 & & \\
\hline 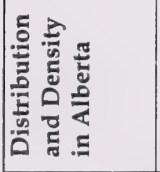 & & & & & & & & 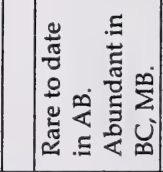 & & \\
\hline 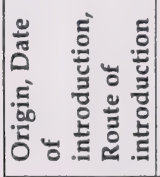 & : & 蒙 & & 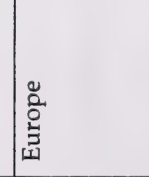 & & 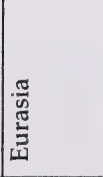 & & 苋 & & 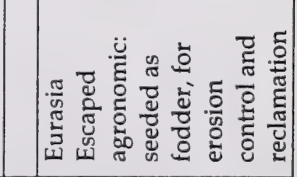 \\
\hline 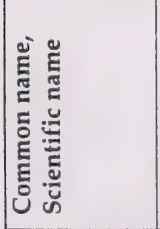 & 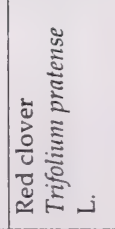 & 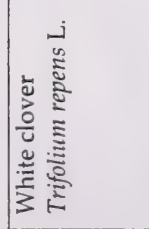 & & 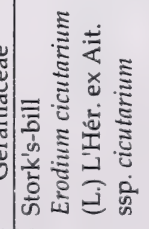 & : & ن. & $\mid$ & 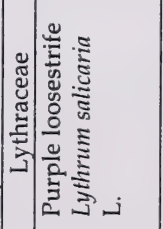 & 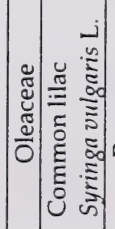 & 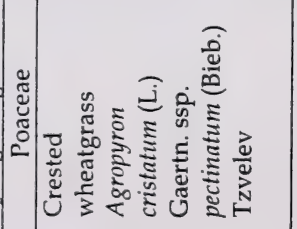 \\
\hline
\end{tabular}




\begin{tabular}{|c|c|c|c|c|c|c|c|c|}
\hline 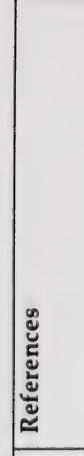 & 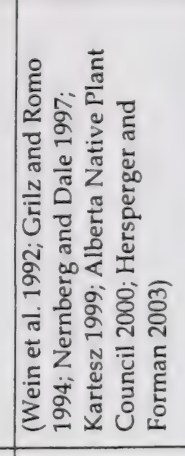 & 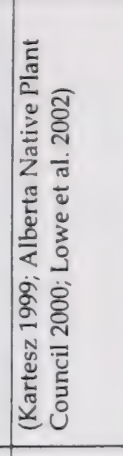 & 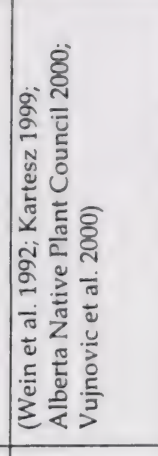 & 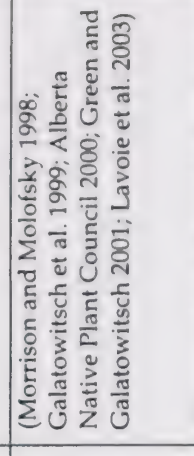 & 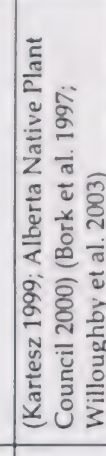 & 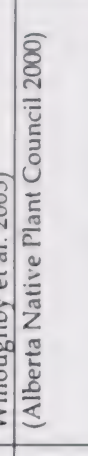 & 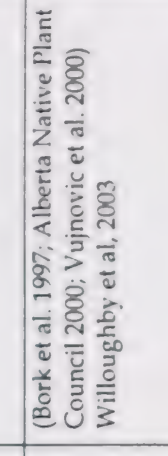 & 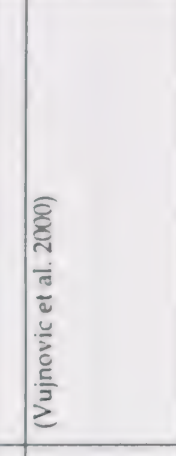 \\
\hline 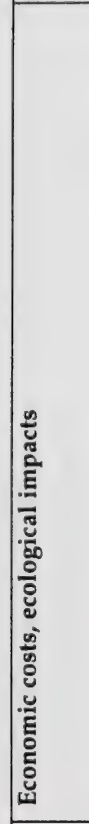 & 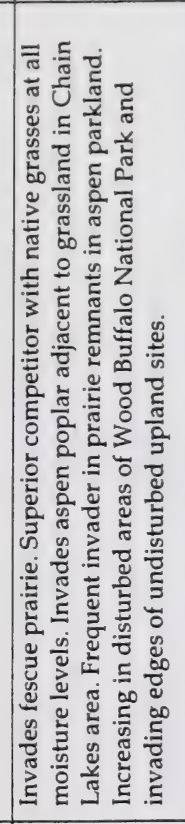 & 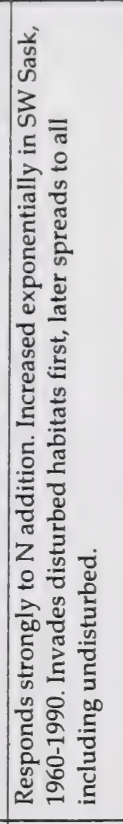 & 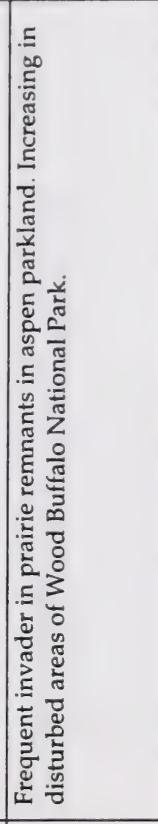 & 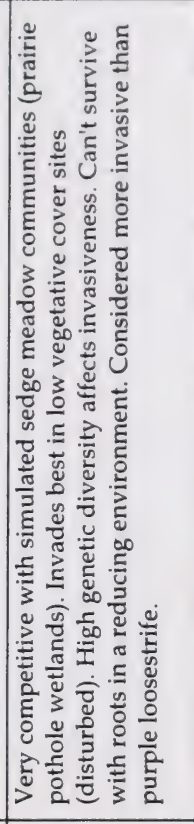 & 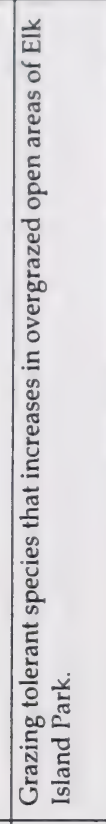 & & 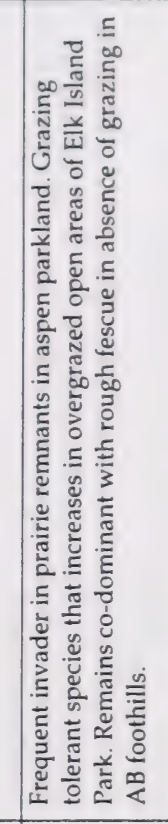 & 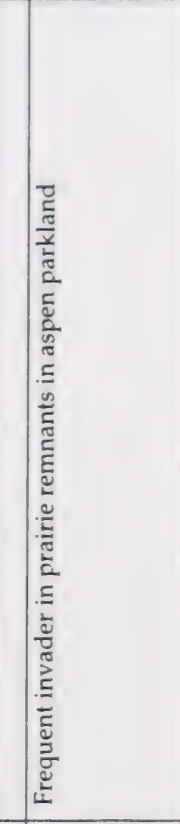 \\
\hline & & 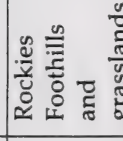 & & 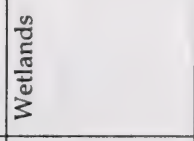 & & & & \\
\hline 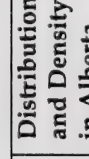 & & & 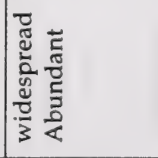 & 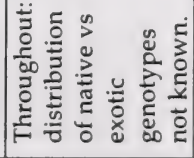 & & & & \\
\hline & 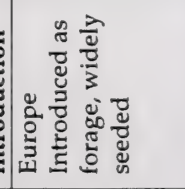 & $\begin{array}{l}0 \\
0 \\
0\end{array}$ & 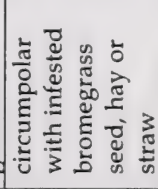 & & & 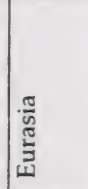 & & \\
\hline 苋 & 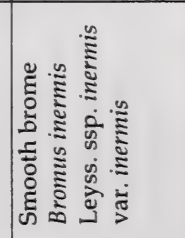 & 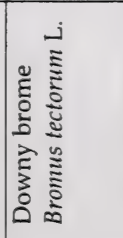 & 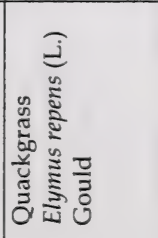 & 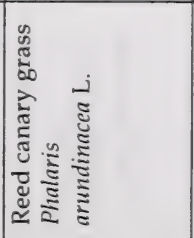 & 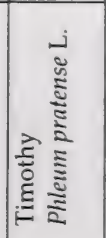 & 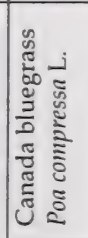 & 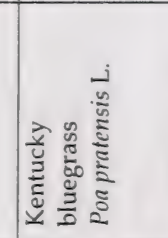 & 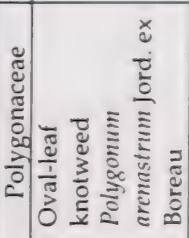 \\
\hline
\end{tabular}




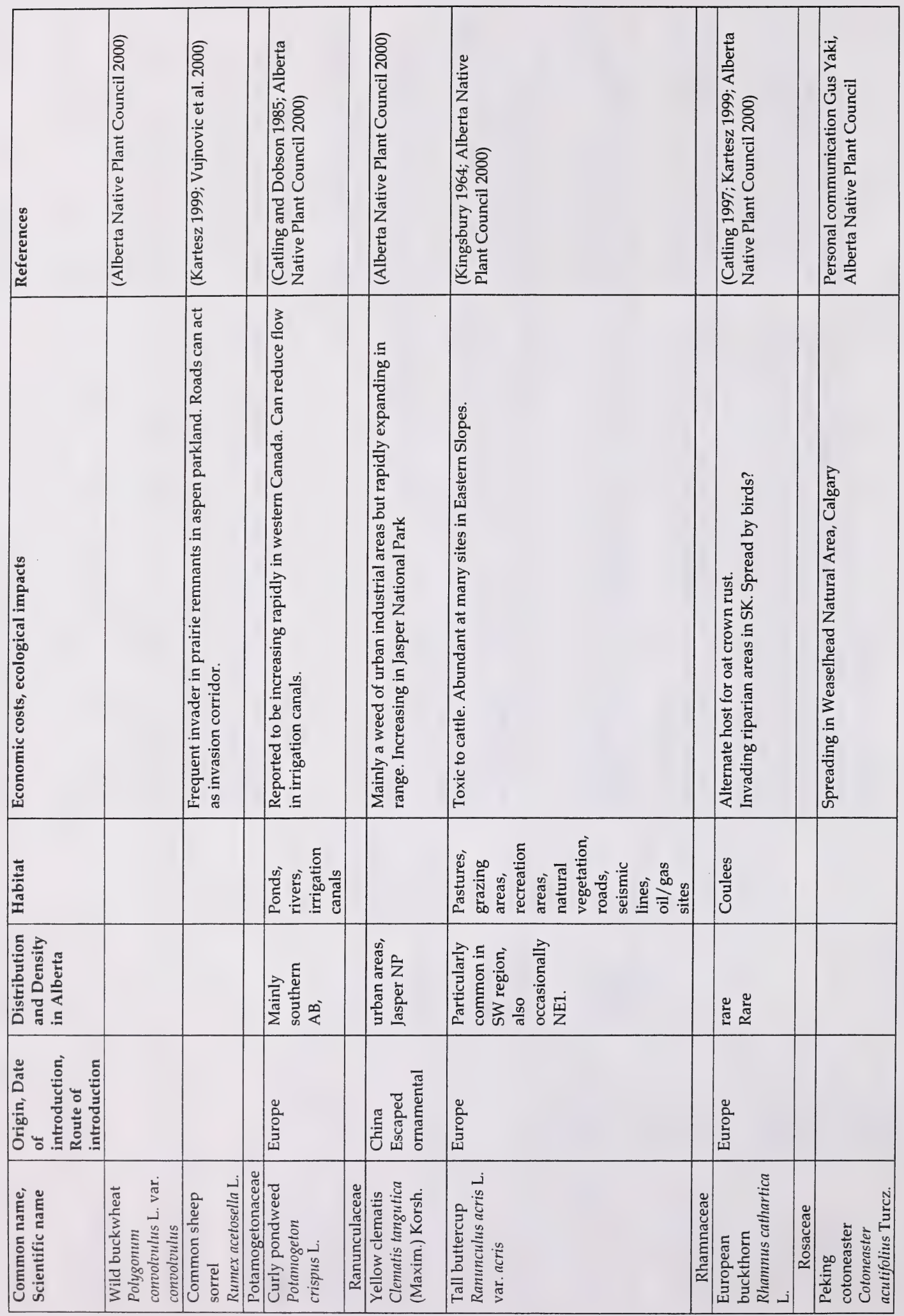




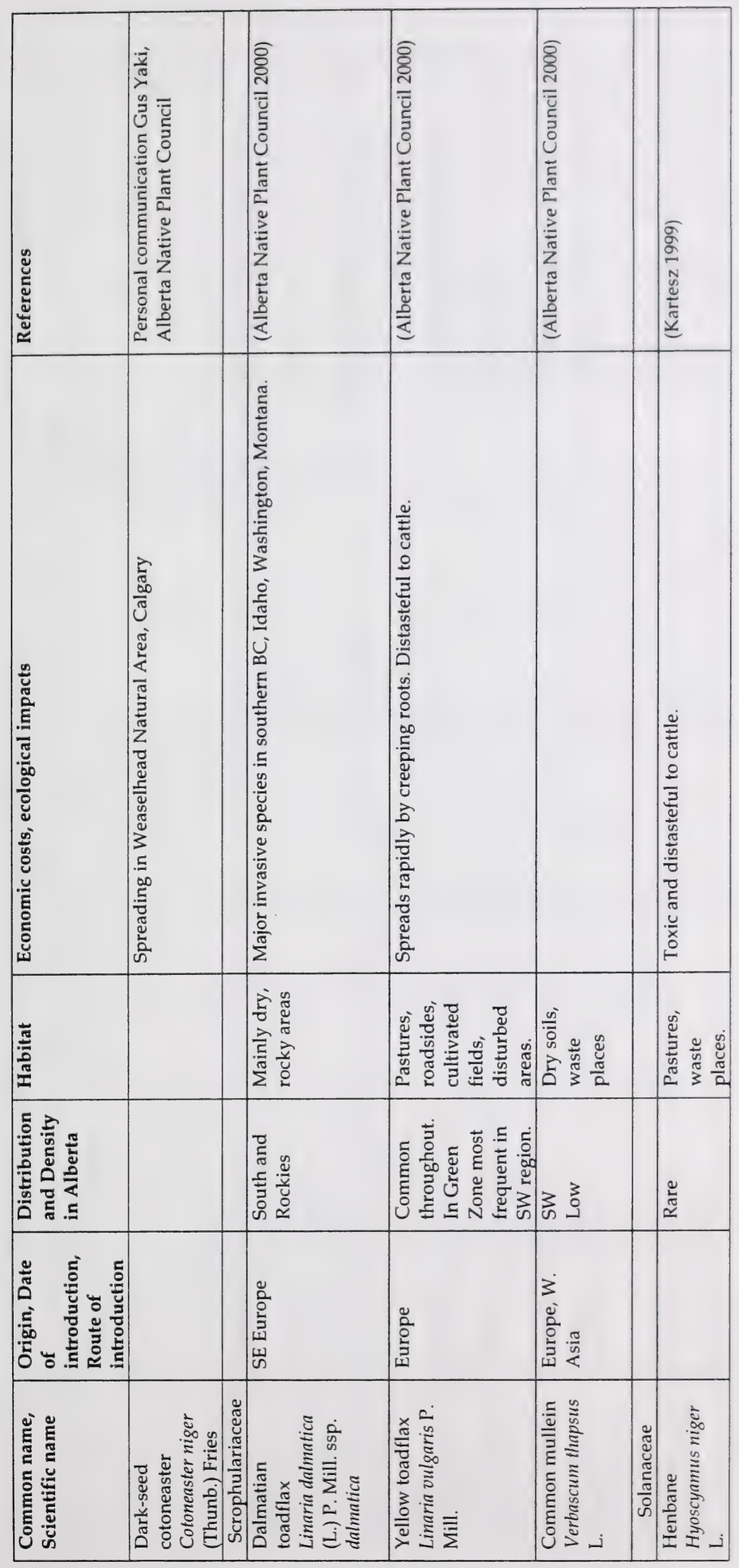



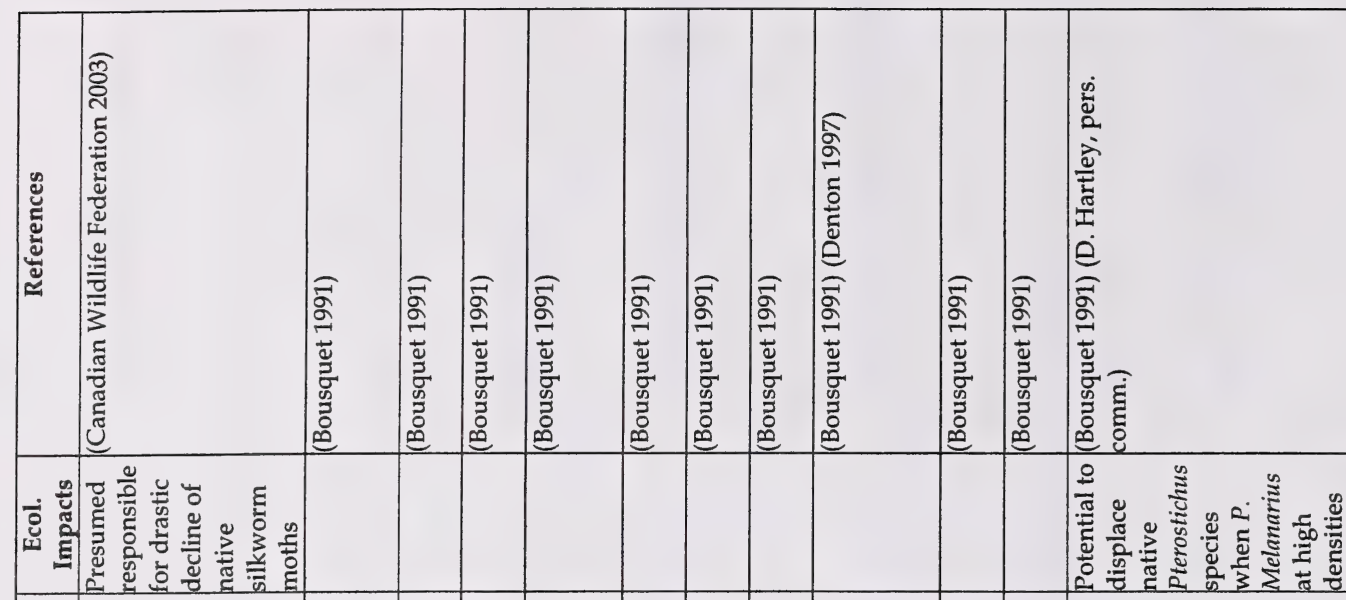

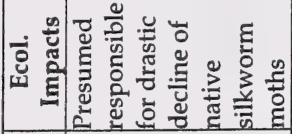

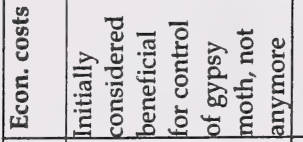

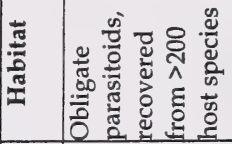

苋

ลั.

.5

胥赵

छ

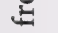

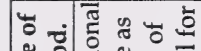

논

苛

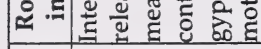

¿

苍

๑.

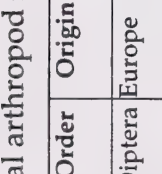

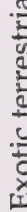

\begin{tabular}{|c|c|c|c|c|c|c|c|c|c|c|c|c|}
\hline 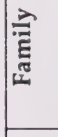 & 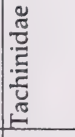 & 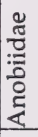 & 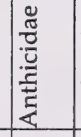 & 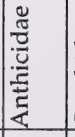 & 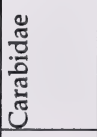 & 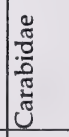 & 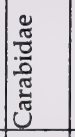 & 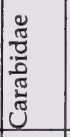 & 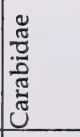 & 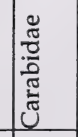 & 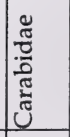 & $\frac{\tilde{\pi}}{\frac{\pi}{0}}$ \\
\hline 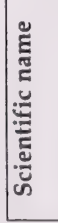 & 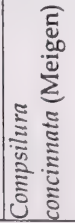 & & 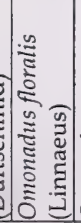 & 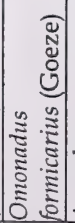 & 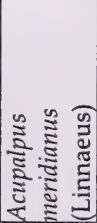 & 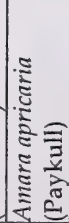 & 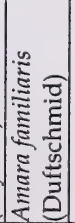 & 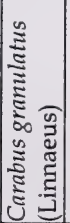 & 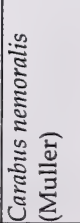 & 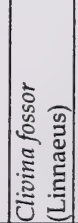 & 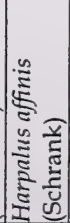 & 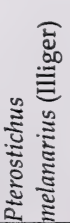 \\
\hline
\end{tabular}




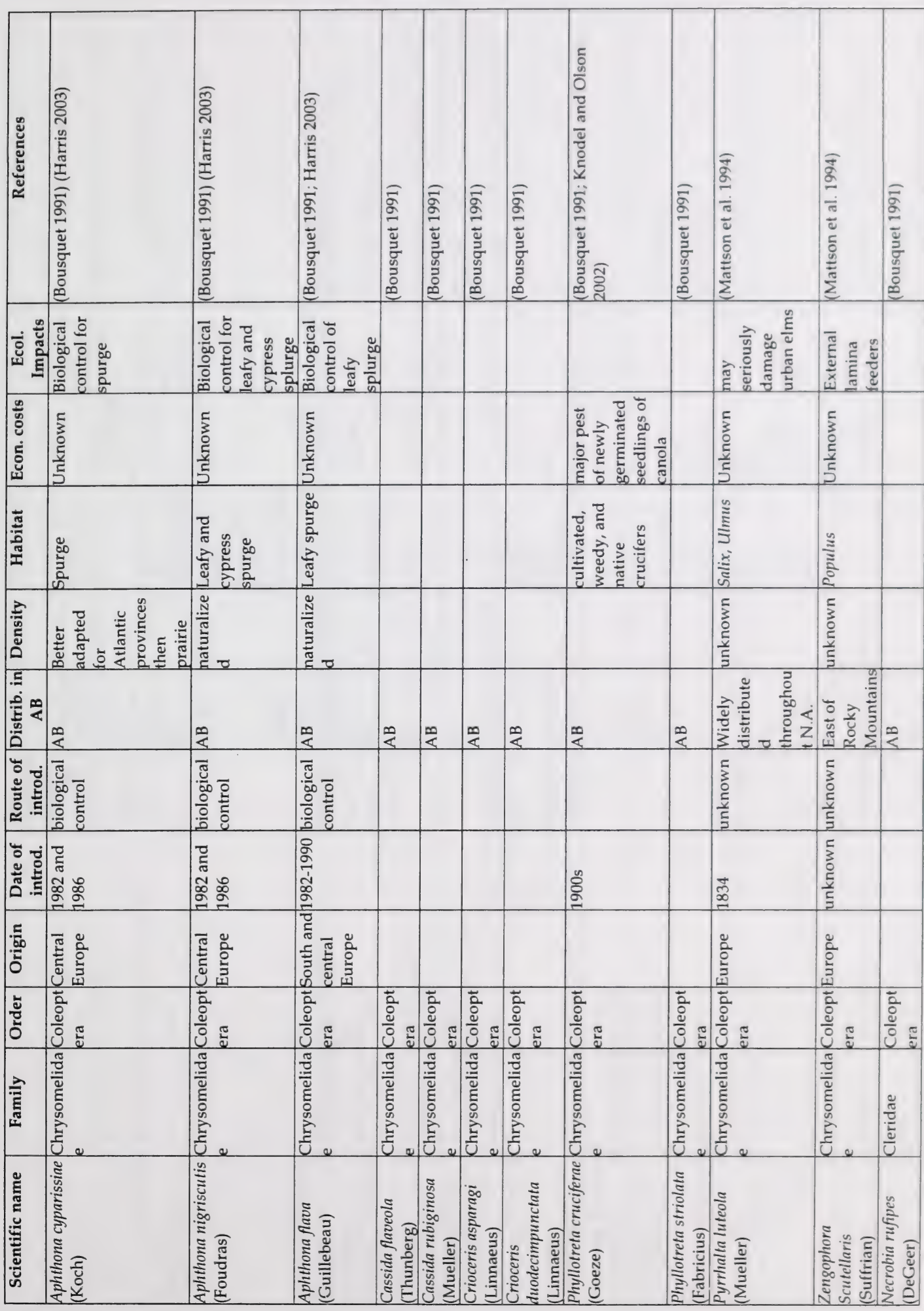




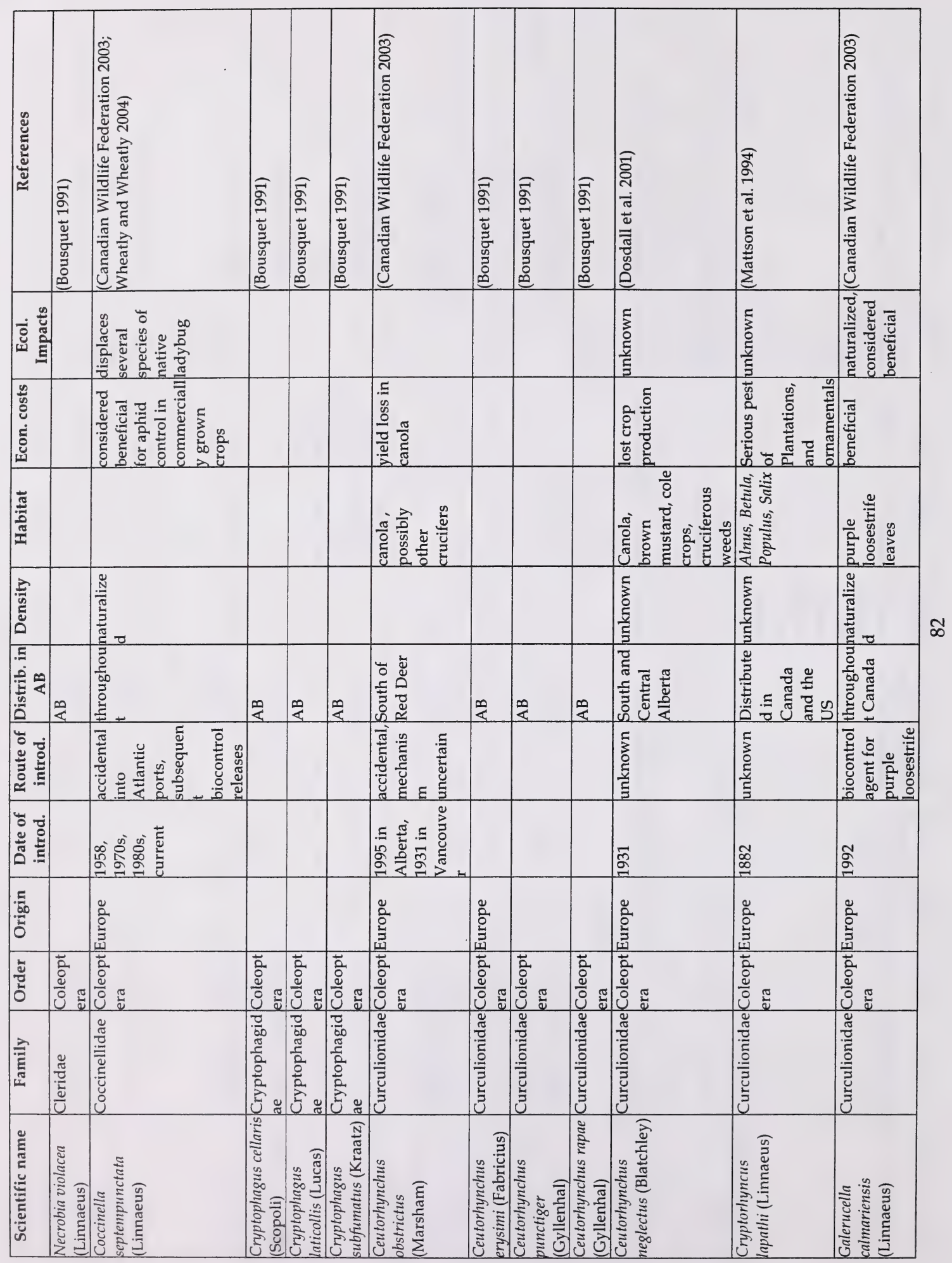




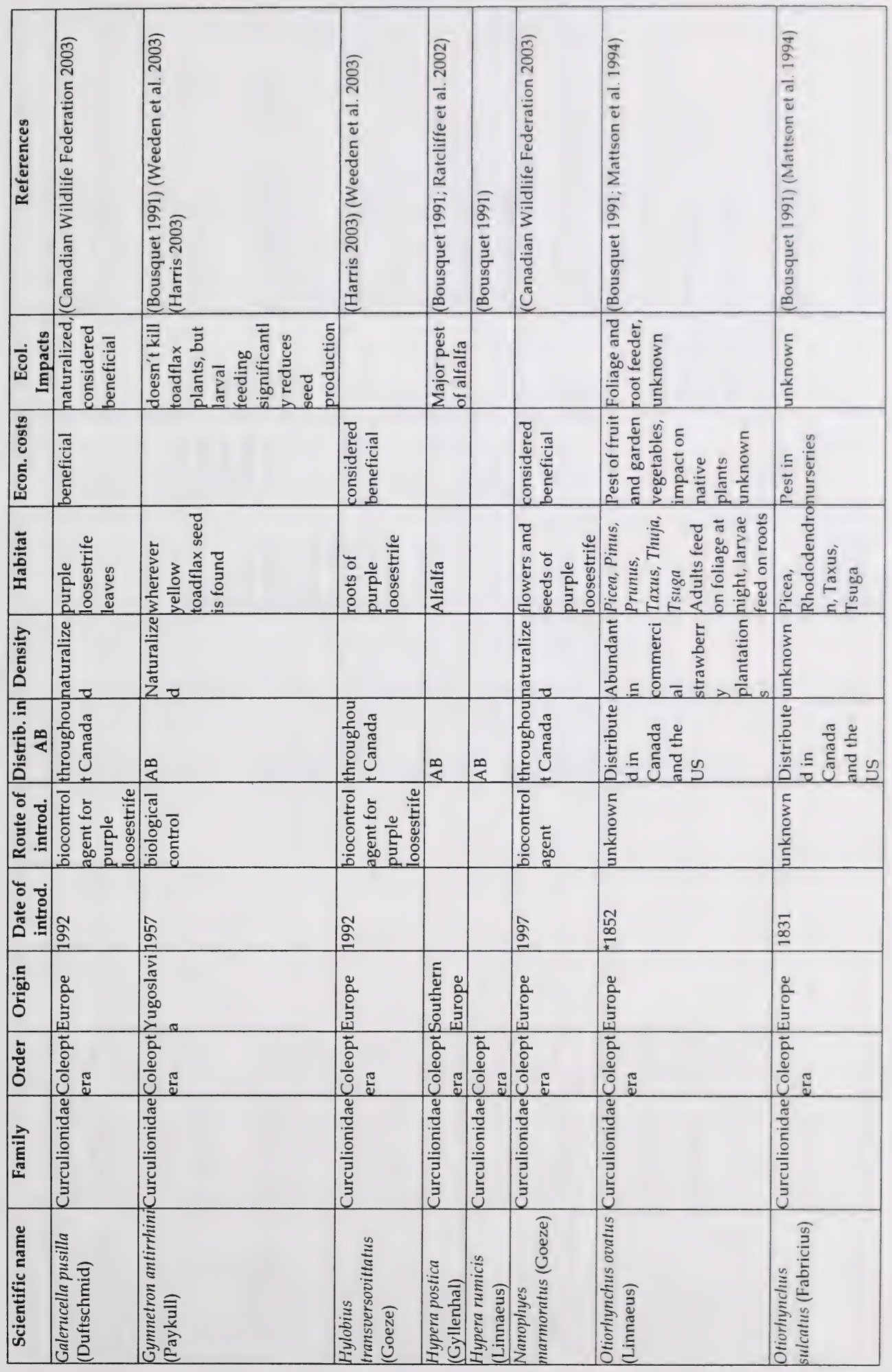



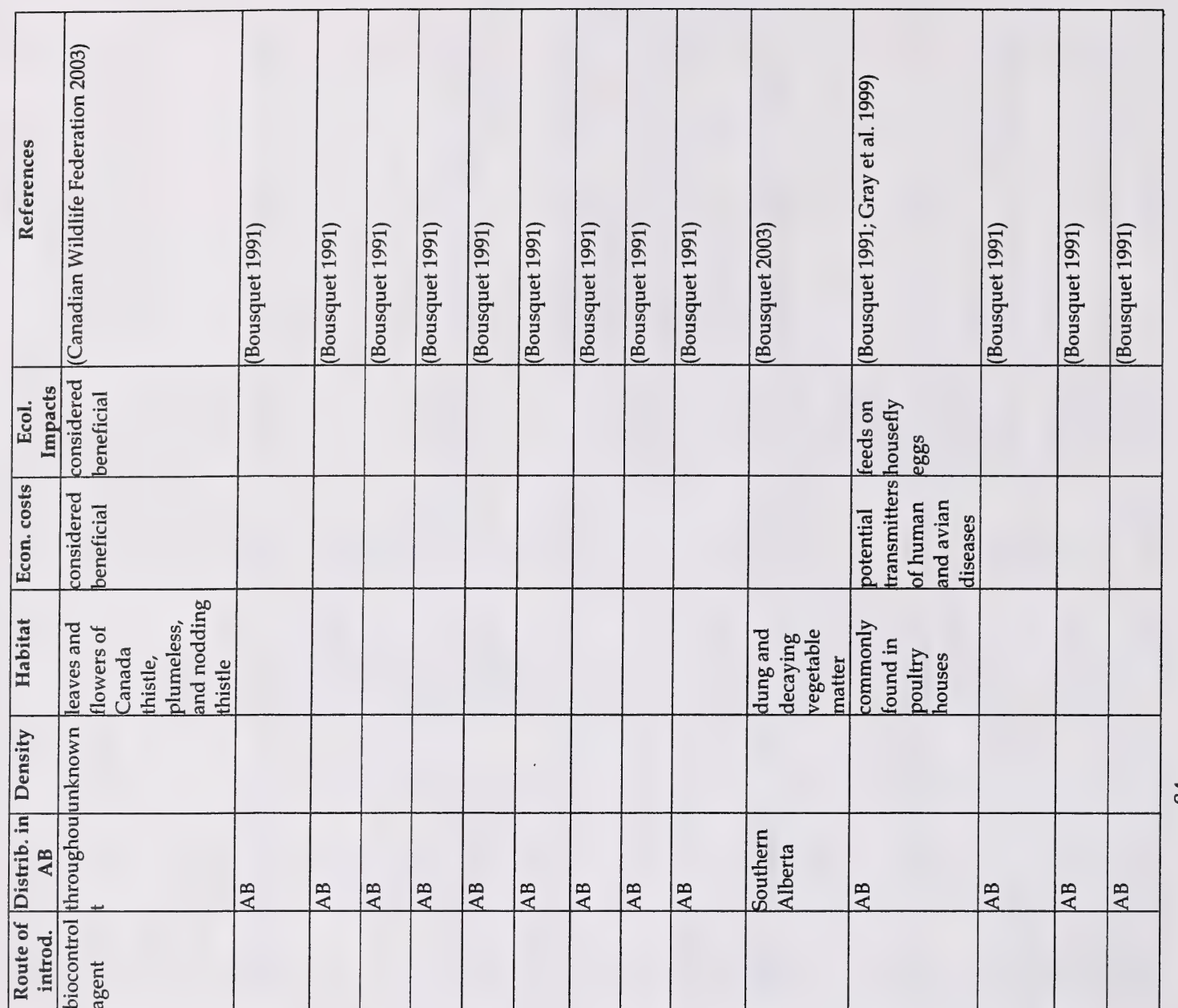

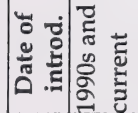

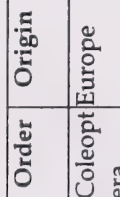

产颜

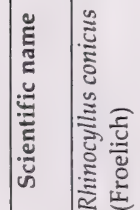

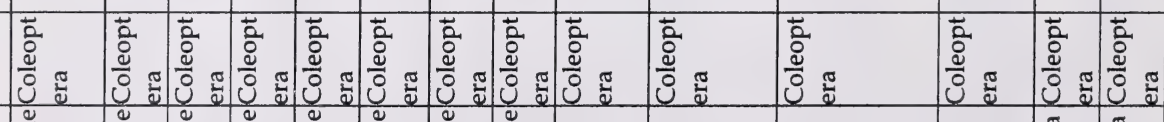

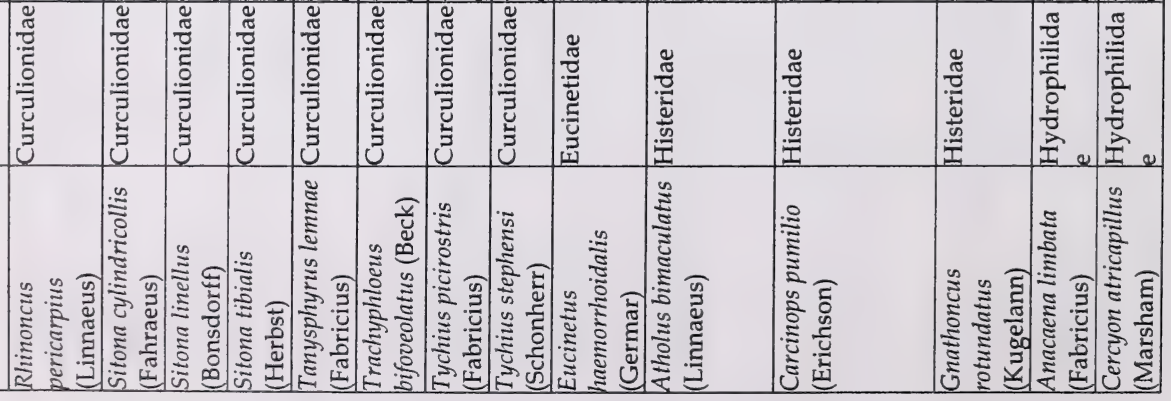




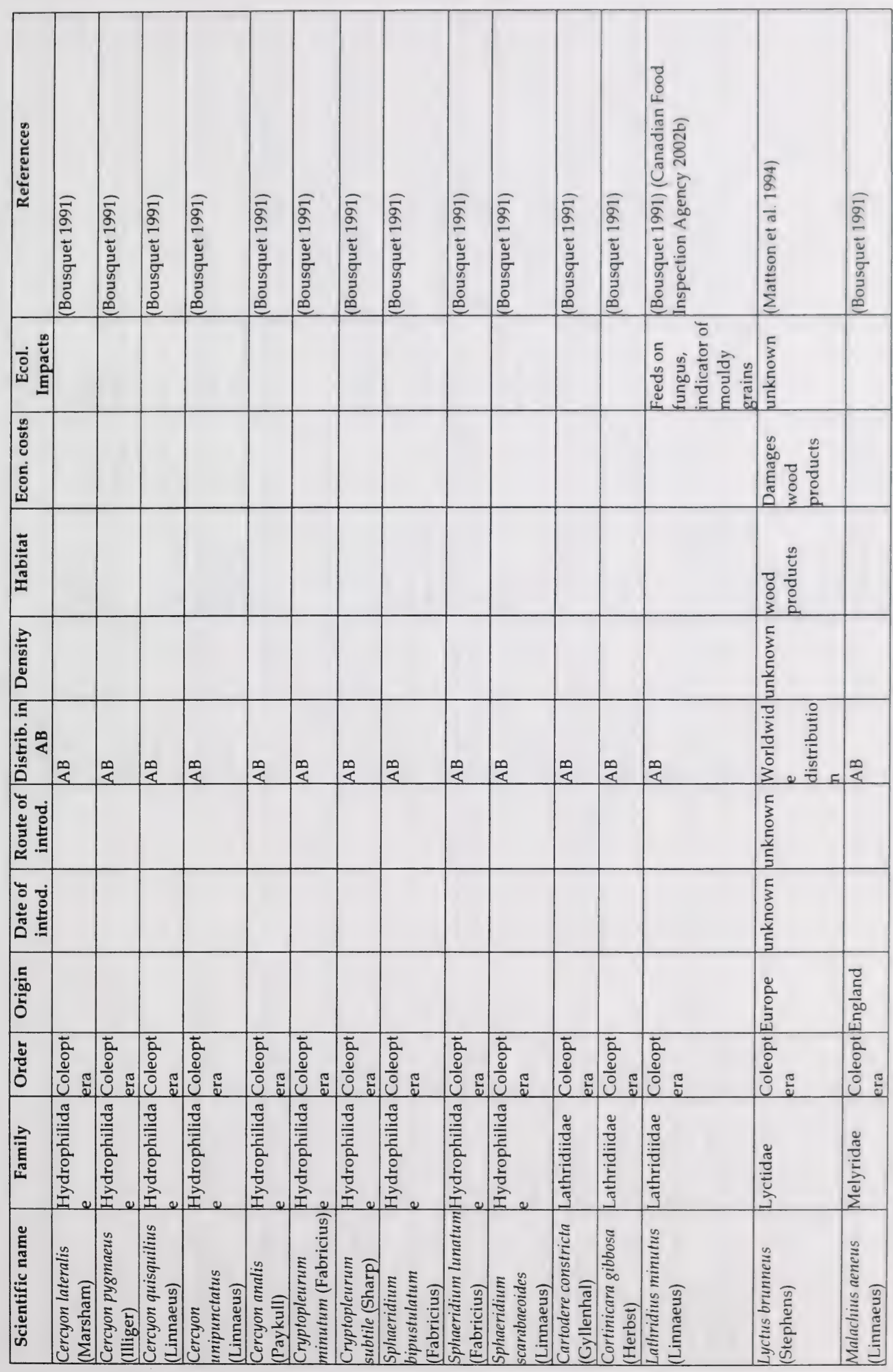




\begin{tabular}{|c|c|c|c|c|c|c|c|c|c|c|c|c|c|c|c|}
\hline 苋 & 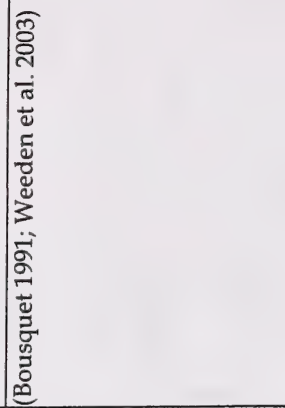 & 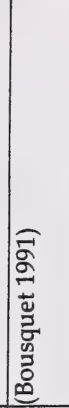 & 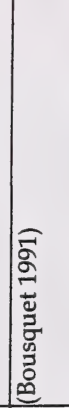 & 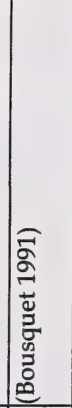 & 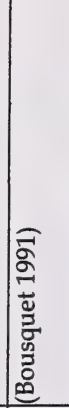 & 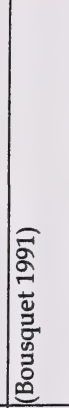 & 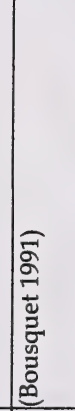 & 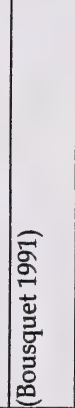 & 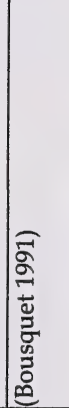 & 䒬 & 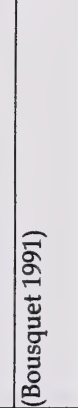 & 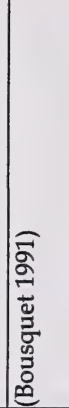 & 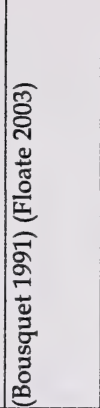 & 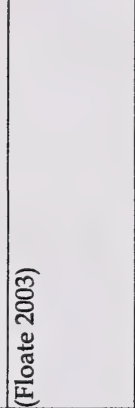 & 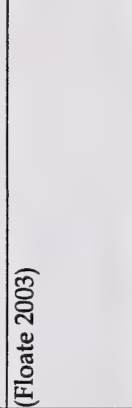 \\
\hline 造 & $\mid \begin{array}{l}\frac{5}{3} \\
0 \\
\frac{5}{5} \\
\frac{5}{3} \\
\end{array}$ & & & & & & & & & & & & 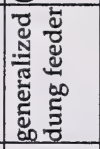 & $\begin{array}{l}\infty \\
\frac{\infty}{3} \\
\frac{2}{2} \\
\frac{\pi}{2} \\
\end{array}$ & 哠 \\
\hline 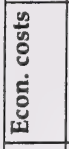 & $\begin{array}{l}5 \\
5 \\
0 \\
\tilde{z} \\
\frac{5}{5} \\
\end{array}$ & & & & & & & & & & & & 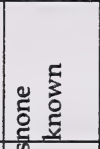 & 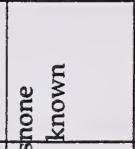 & 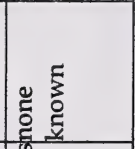 \\
\hline 竎 & 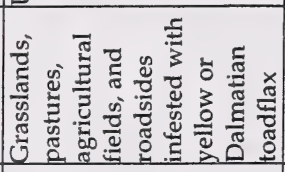 & & & & & & & & & & & & 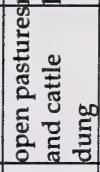 & 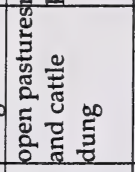 & 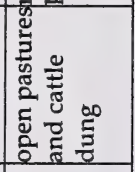 \\
\hline 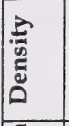 & \begin{tabular}{|l|l|} 
\\
$\vdots$ \\
0 \\
$\vdots$ \\
5 \\
5 \\
\end{tabular} & & & & & & & & & & & & 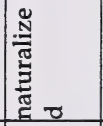 & 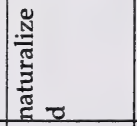 & $\frac{\pi}{\frac{\pi}{\pi}}$ \\
\hline 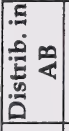 & $\frac{1}{4}$ & $\frac{\infty}{<}$ & $\frac{\infty}{4}$ & $\stackrel{\infty}{<}$ & $\frac{\infty}{<}$ & $\frac{m}{4}$ & $\stackrel{\infty}{<}$ & $\stackrel{2}{<}$ & $\stackrel{2}{<}$ & $\frac{\infty}{<}$ & $\stackrel{\infty}{<}$ & $\frac{\infty}{<}$ & $\stackrel{\infty}{<}$ & 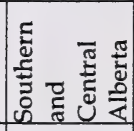 & 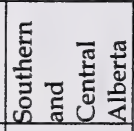 \\
\hline \begin{tabular}{|c|c|} 
\\
0
\end{tabular} & 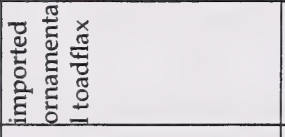 & & & & & & & & & & & & & & \\
\hline 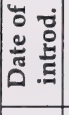 & ڤ్సి & & & & & & & & & & & & & & \\
\hline 5 & 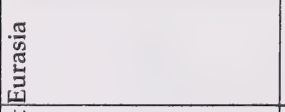 & & & & & & & & & & & & 荾 & 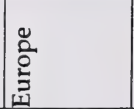 & 农 \\
\hline ठّ & 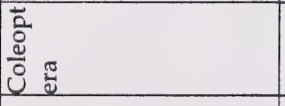 & 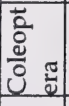 & \begin{tabular}{|l|}
$\overrightarrow{0}$ \\
$\frac{0}{0}$ \\
0 \\
0 \\
0
\end{tabular} & 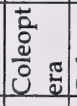 & 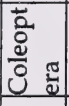 & 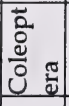 & \begin{tabular}{|l|}
$\overrightarrow{0}$ \\
0 \\
0 \\
0 \\
0 \\
0
\end{tabular} & 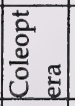 & 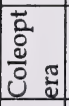 & \begin{tabular}{|l|}
$\overrightarrow{0}$ \\
0 \\
0 \\
0 \\
0
\end{tabular} & 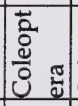 & $\begin{array}{l}\overrightarrow{0} \\
0 \\
0 \\
0 \\
0\end{array}$ & 蒙 & 递 & 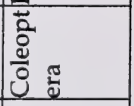 \\
\hline 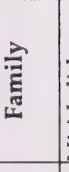 & 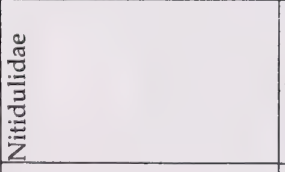 & 莡 & 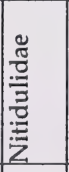 & 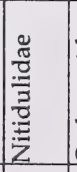 & 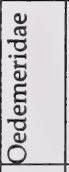 & 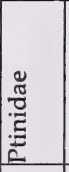 & 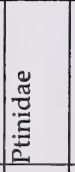 & 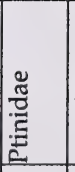 & 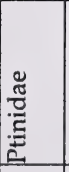 & 苋 & 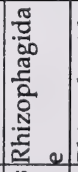 & 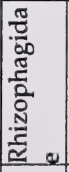 & 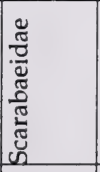 & 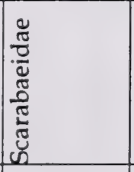 & 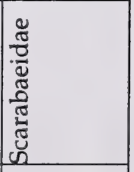 \\
\hline 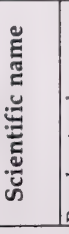 & 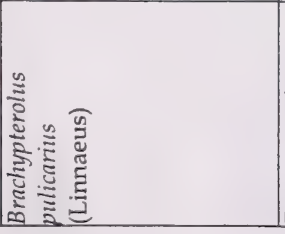 & 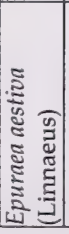 & 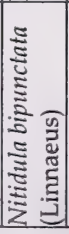 & 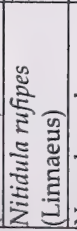 & 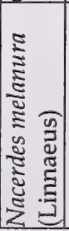 & 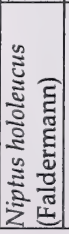 & 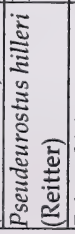 & 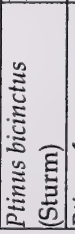 & 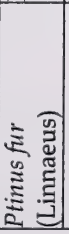 & 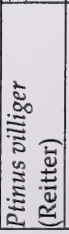 & 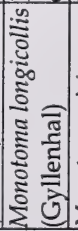 & 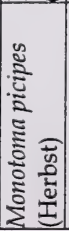 & 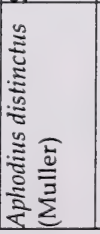 & 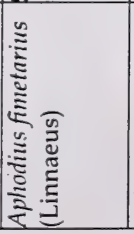 & 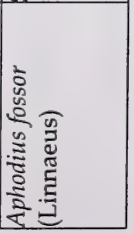 \\
\hline
\end{tabular}




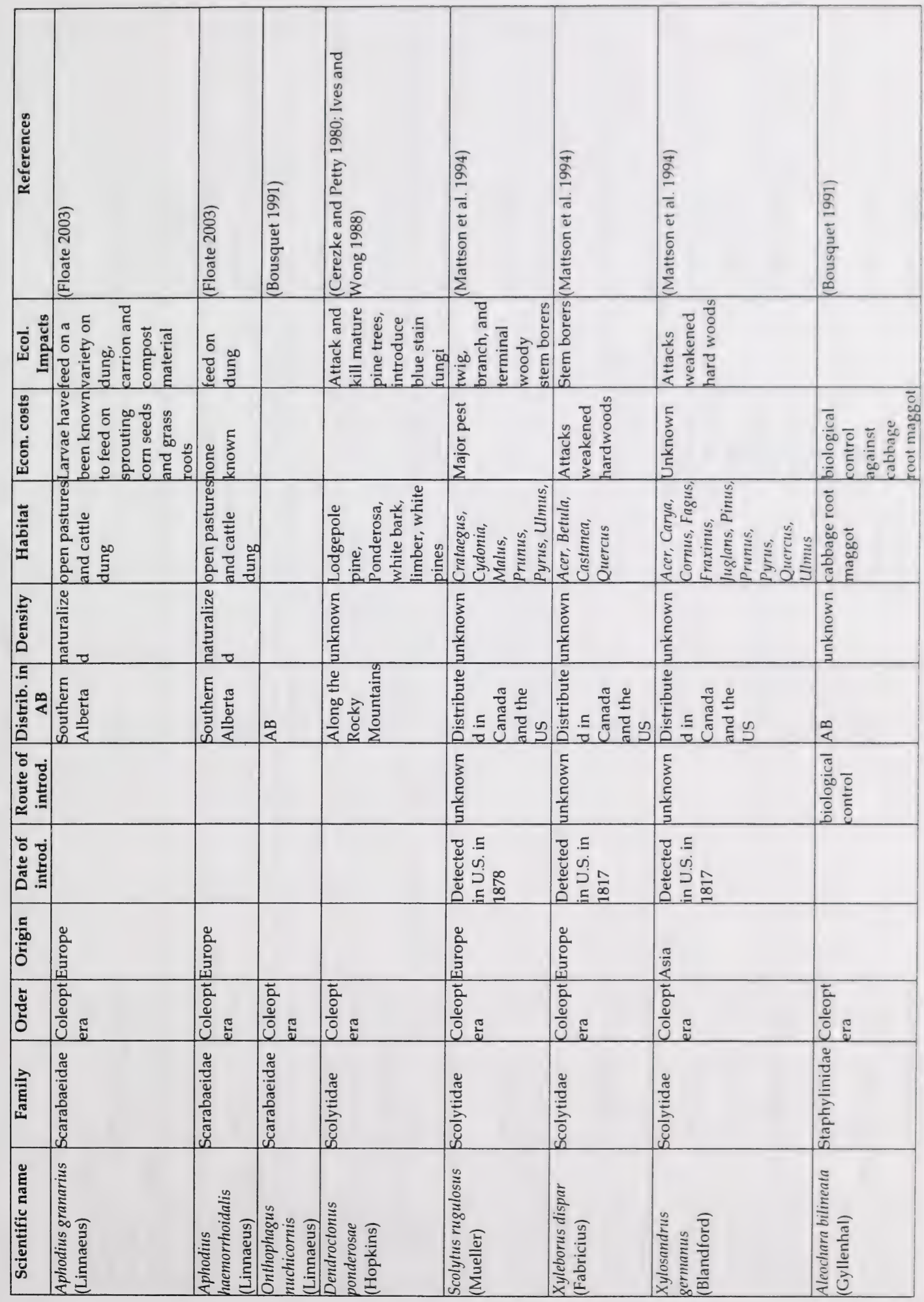




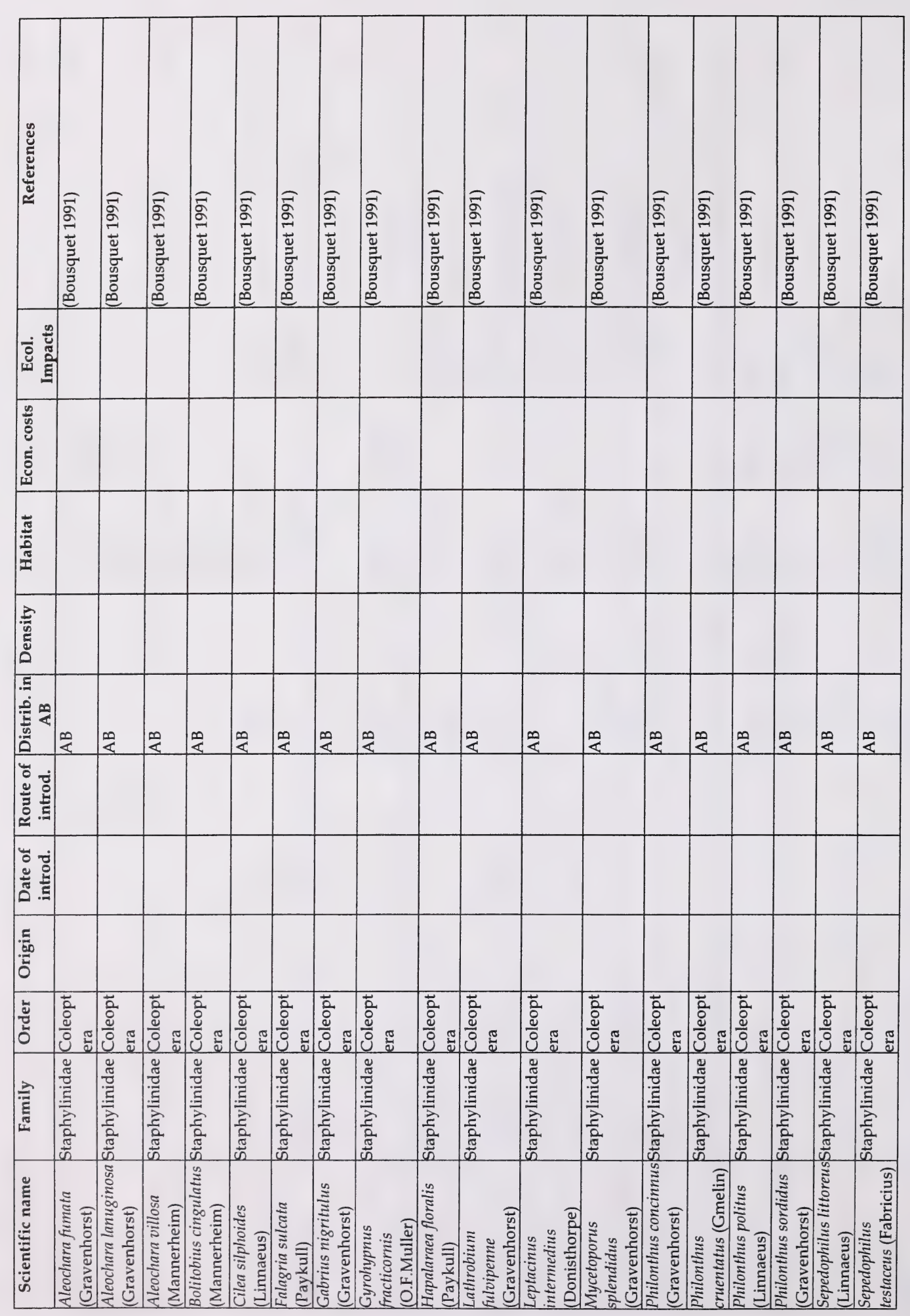

$\infty$ 


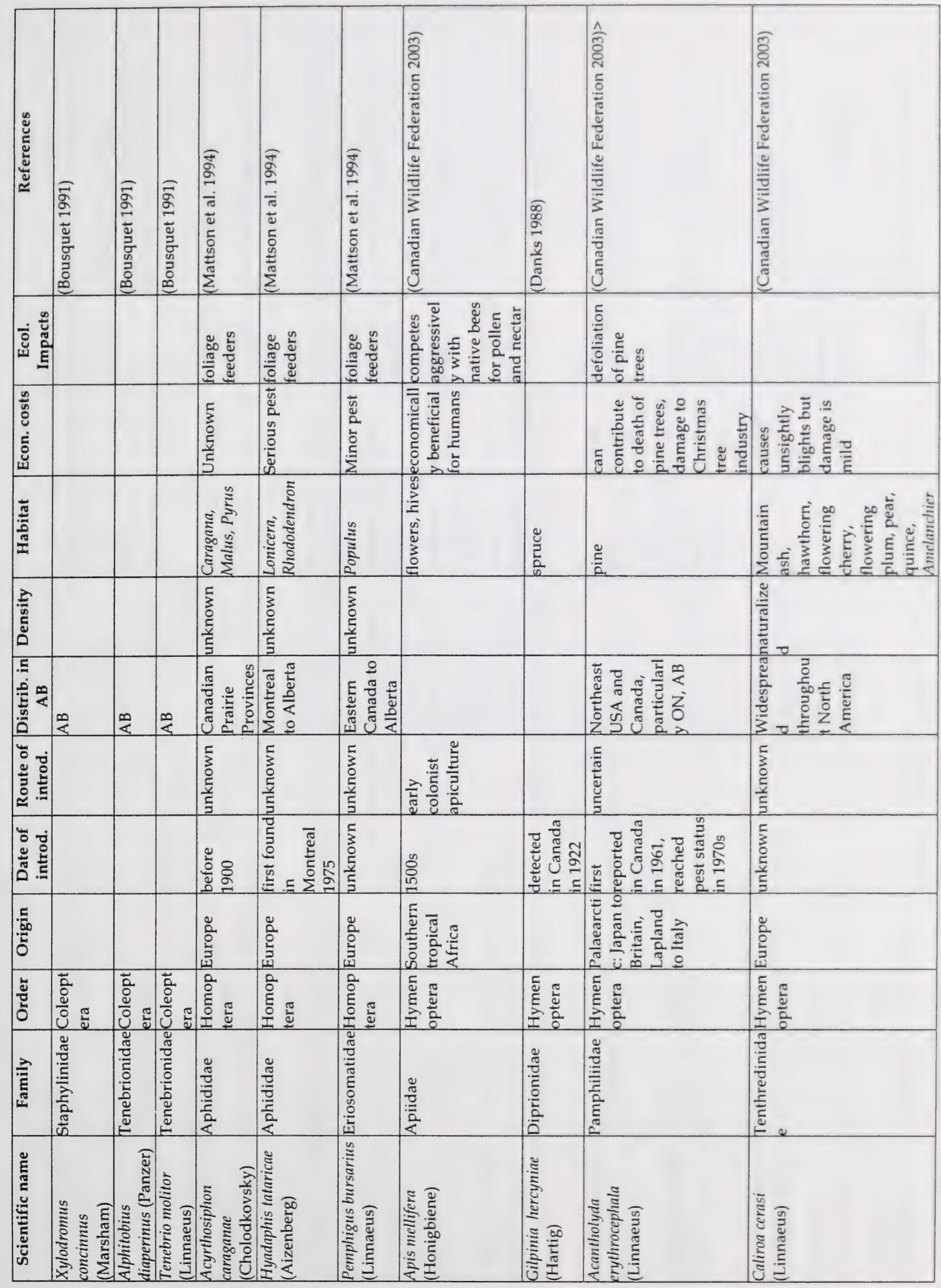

$\infty$ 


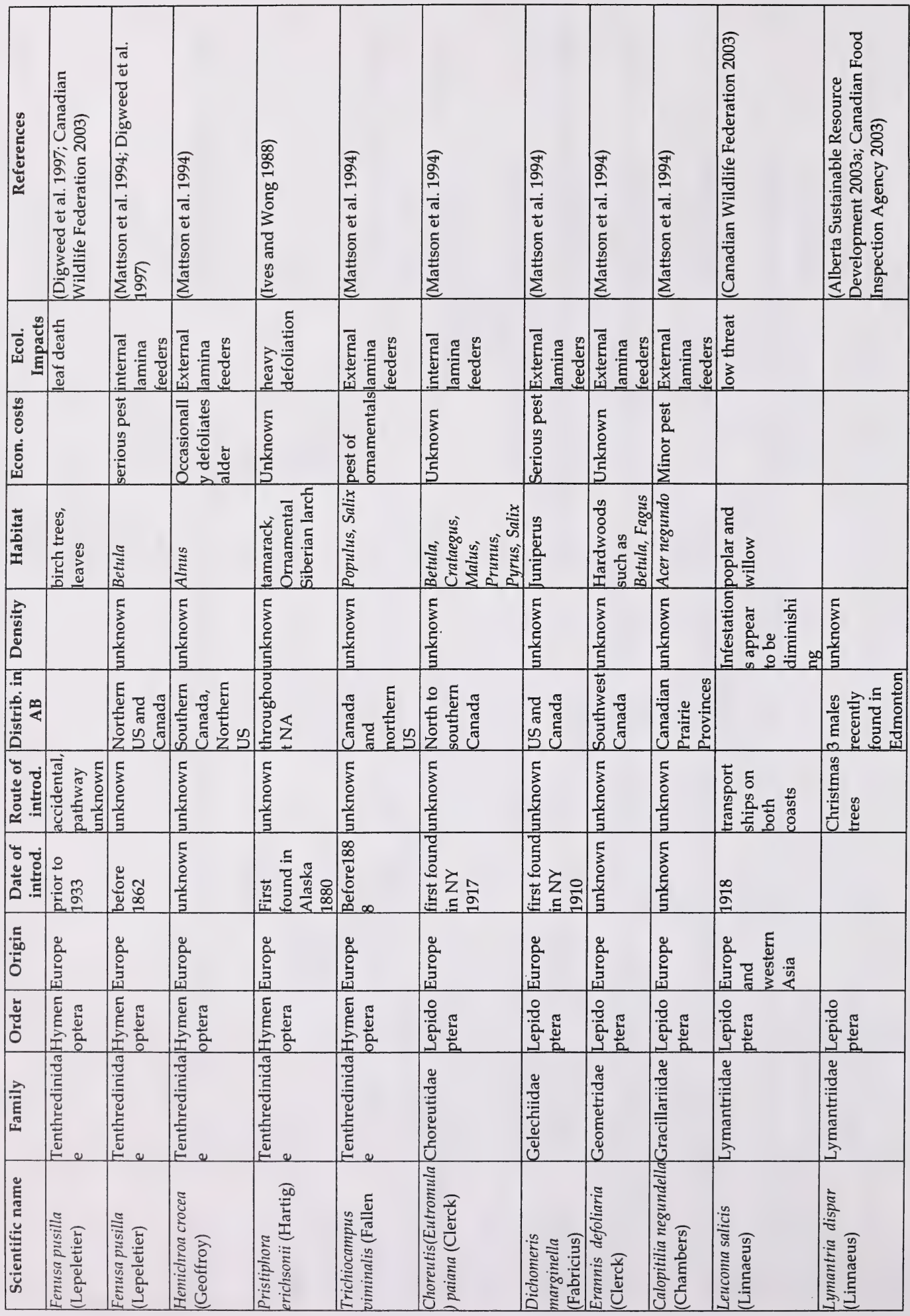




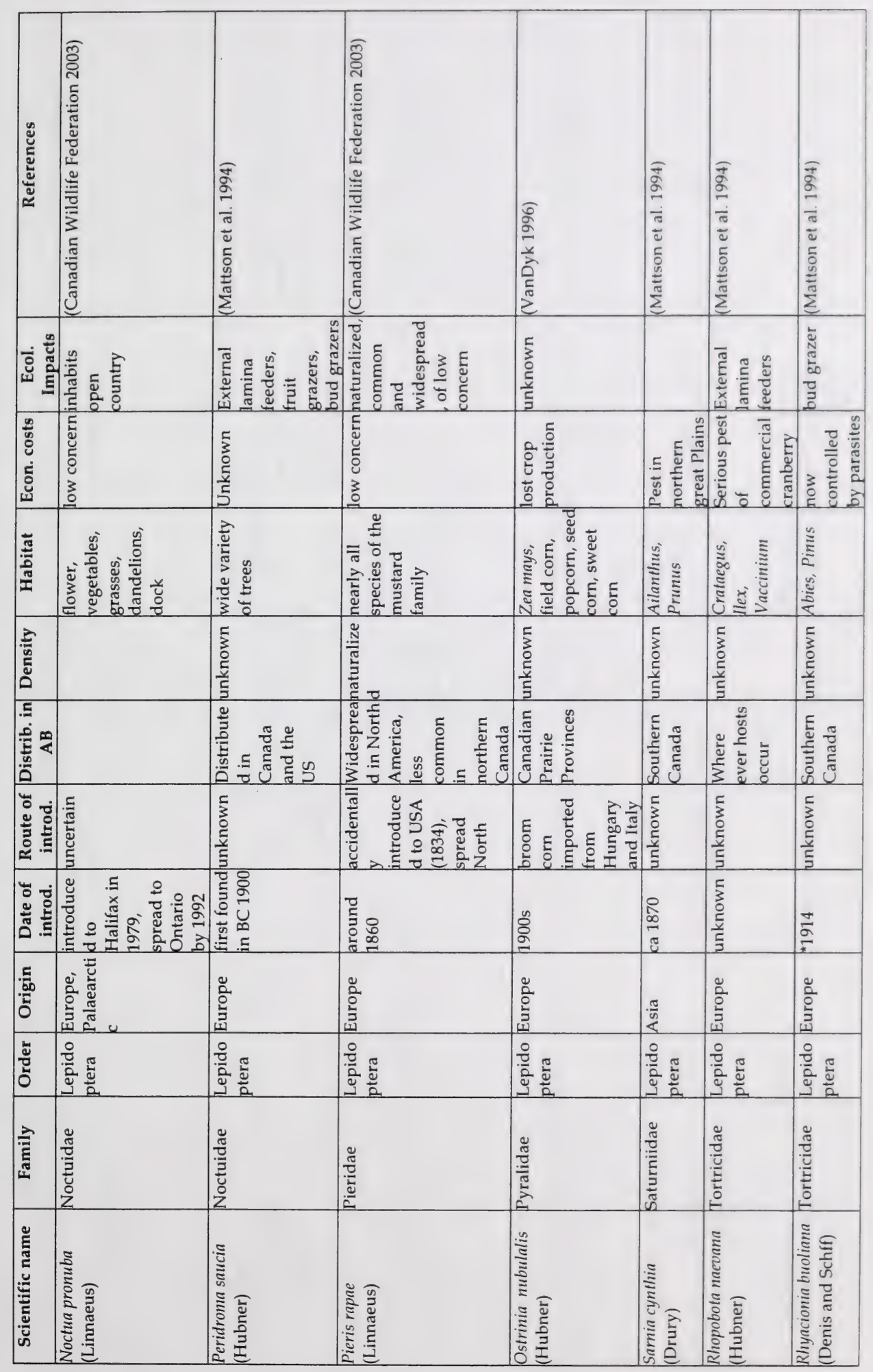




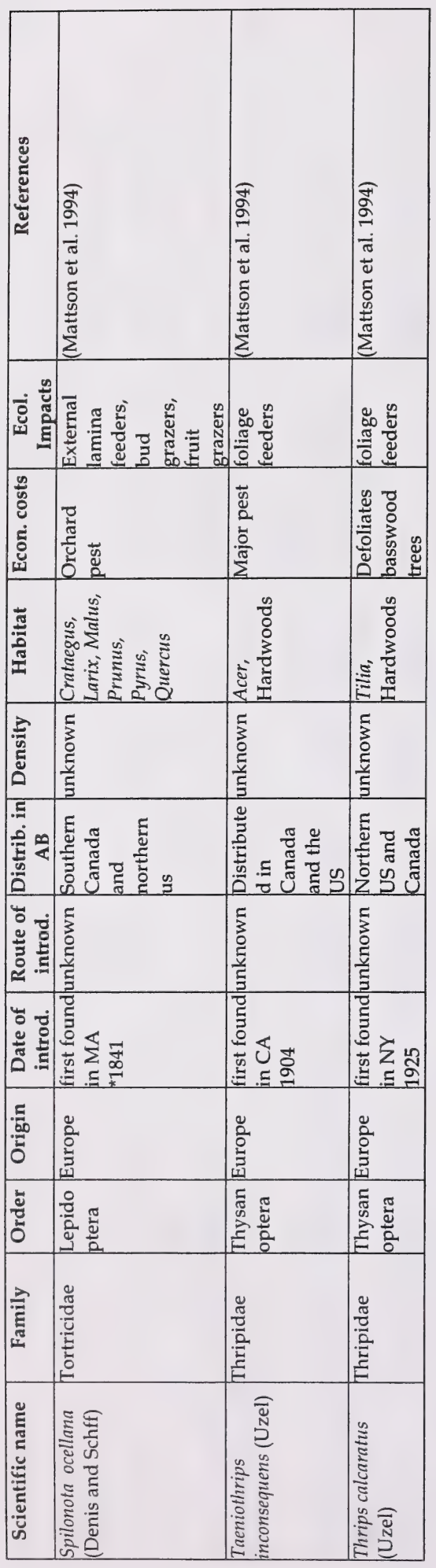

ส 


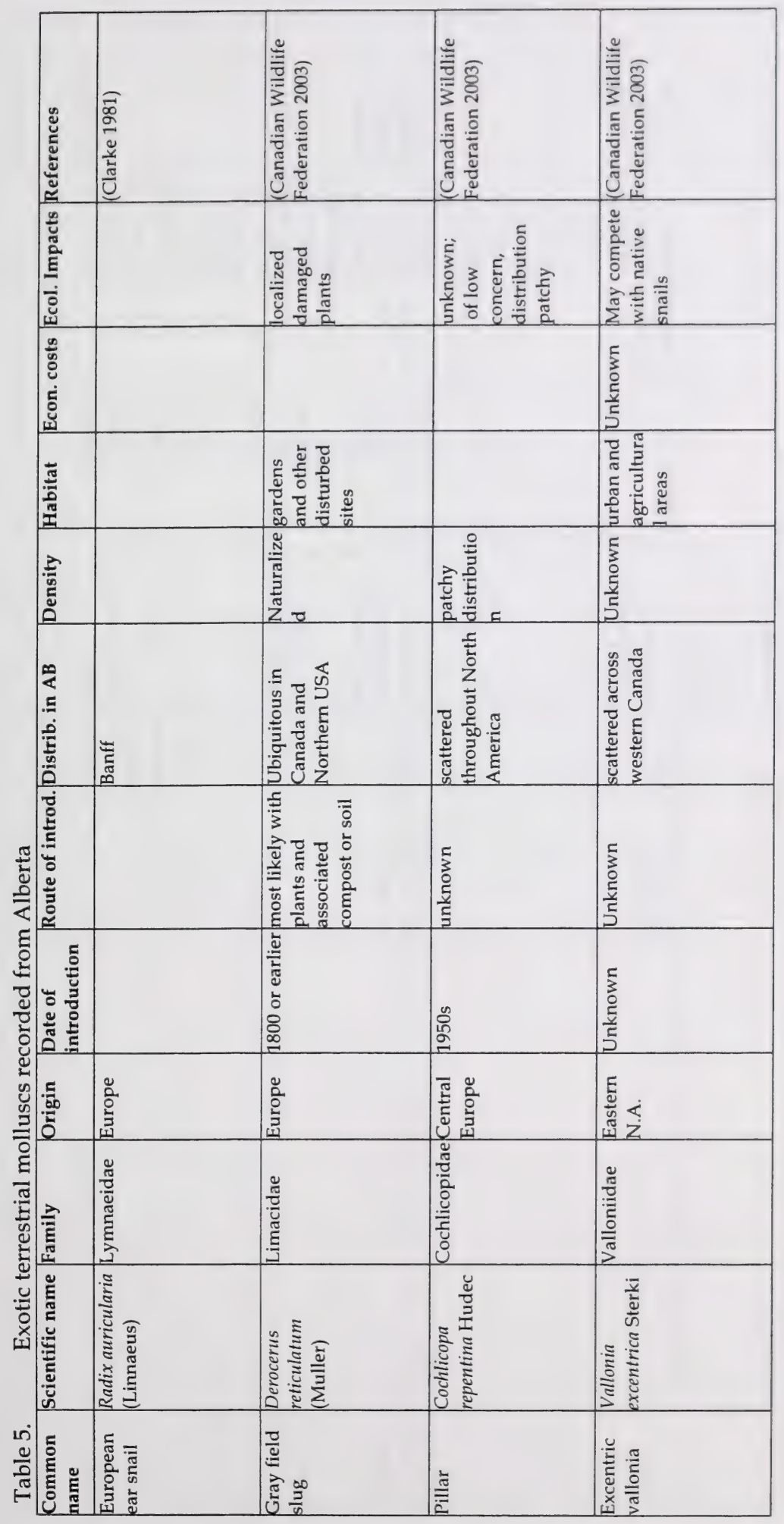




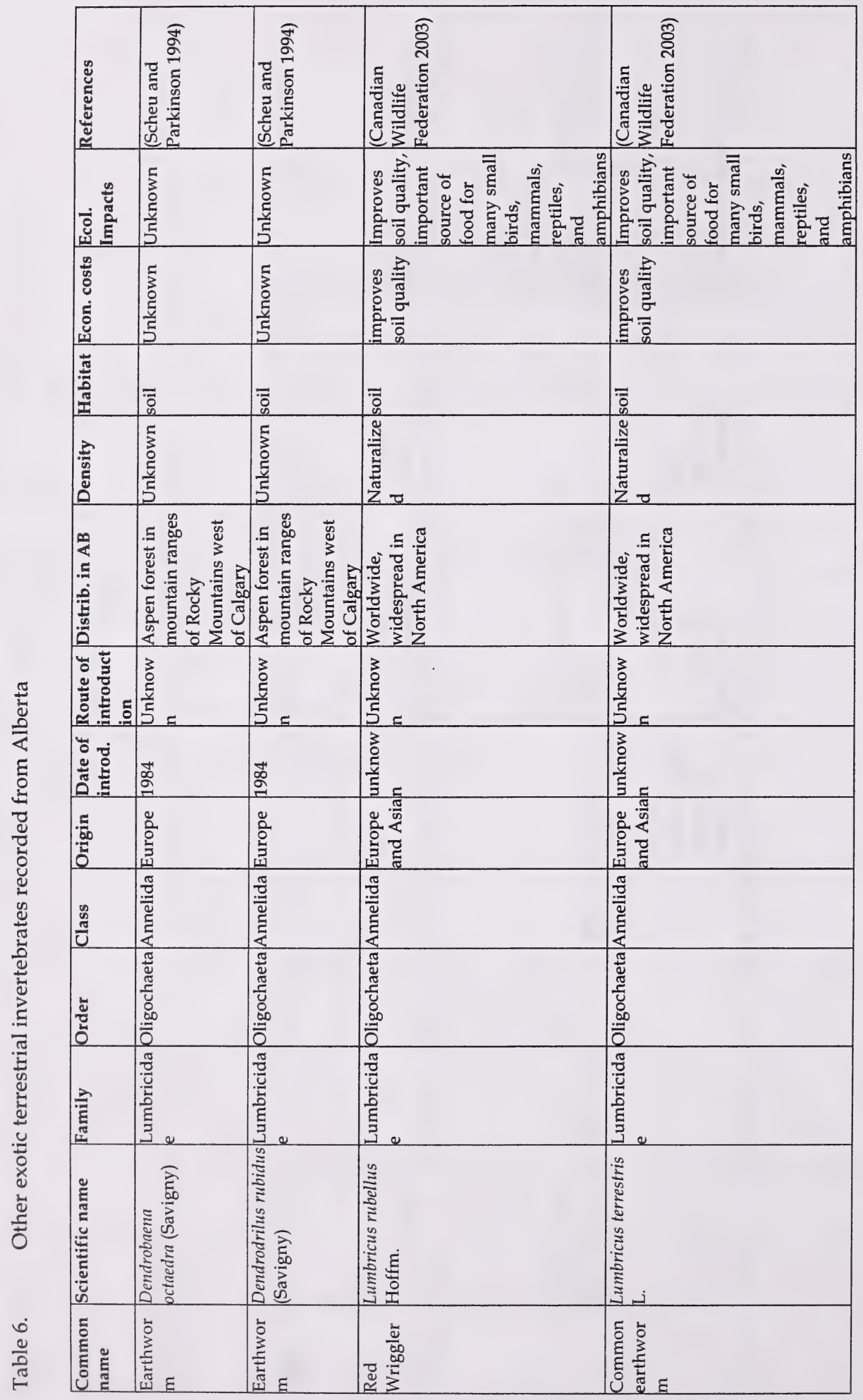




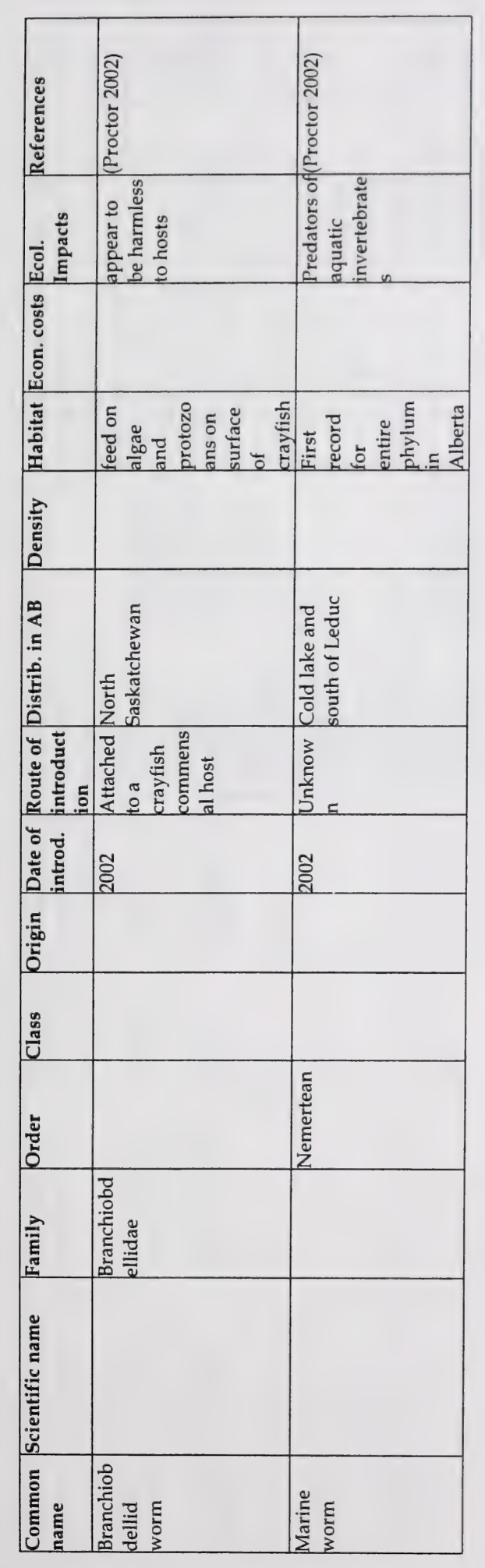




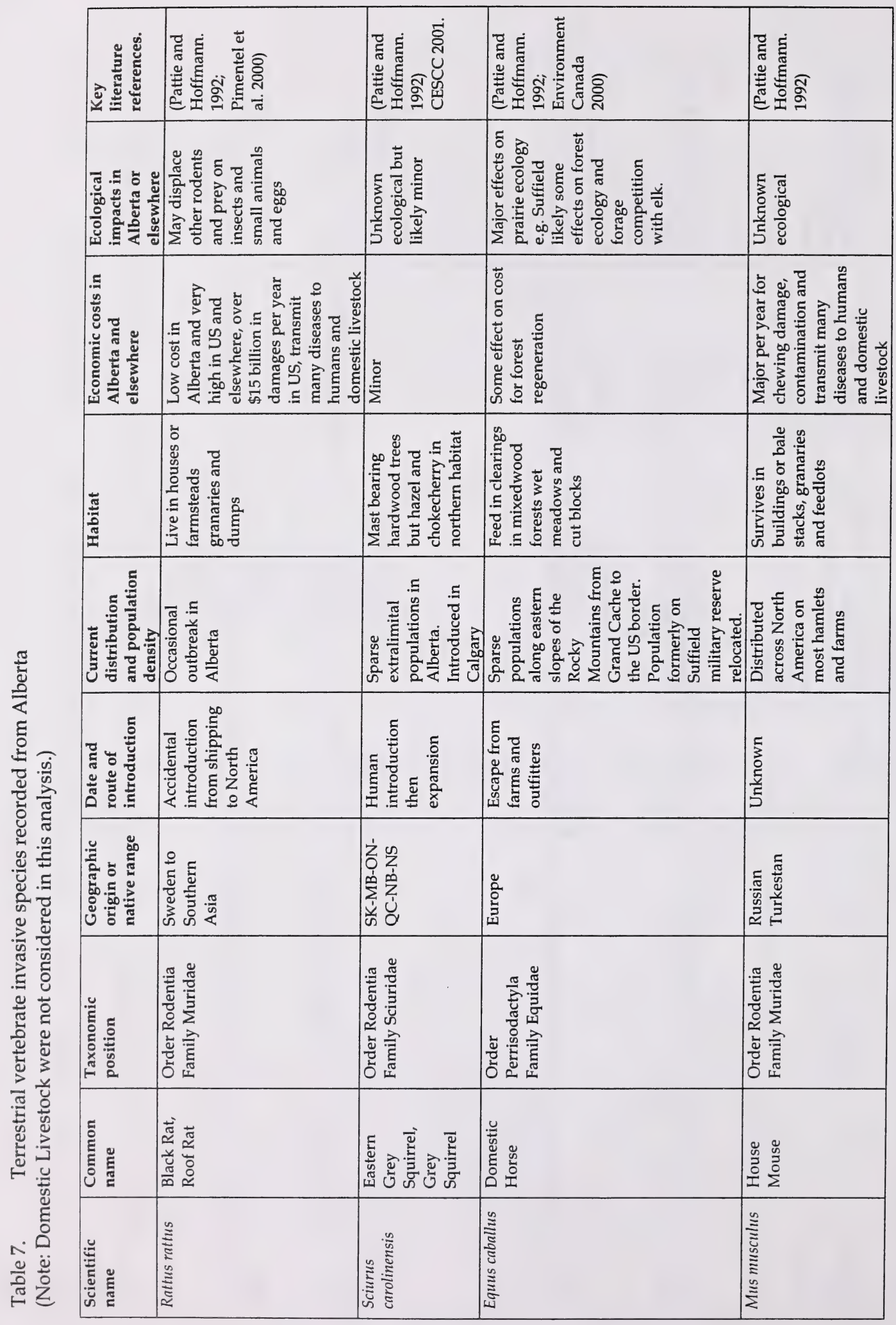




\begin{tabular}{|c|c|c|c|c|}
\hline 窟 & 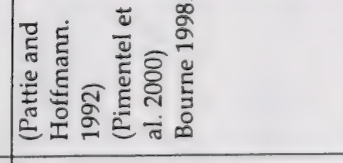 & 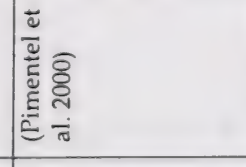 & 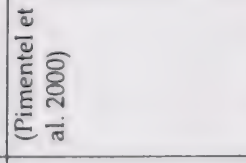 & 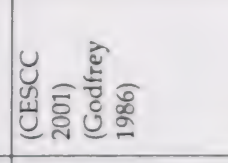 \\
\hline 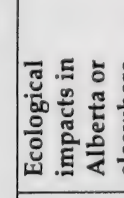 & 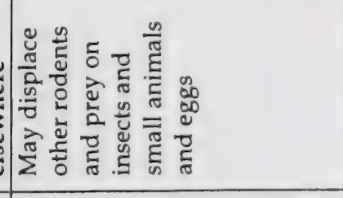 & 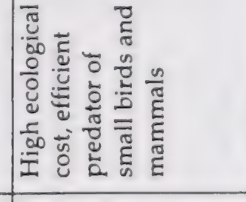 & 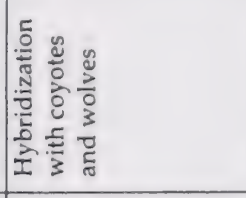 & 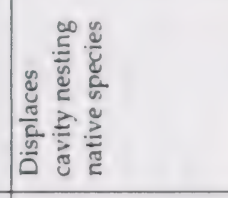 \\
\hline 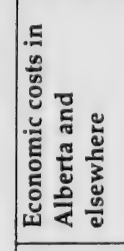 & 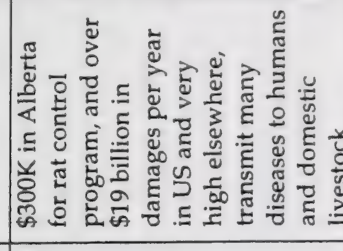 & 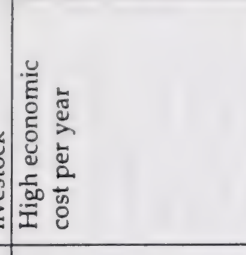 & 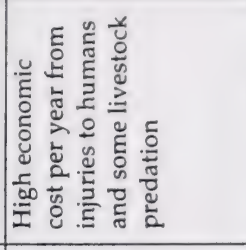 & 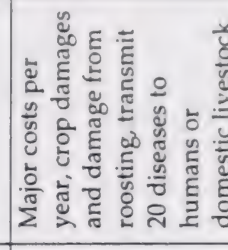 \\
\hline & 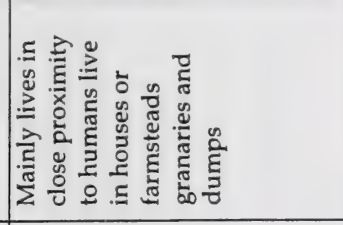 & 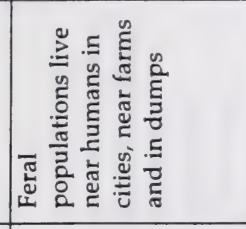 & 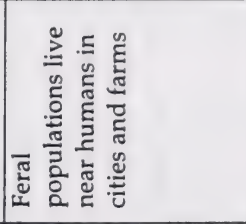 & 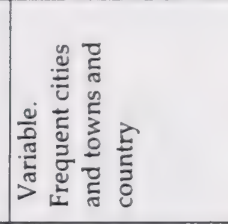 \\
\hline 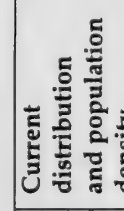 & 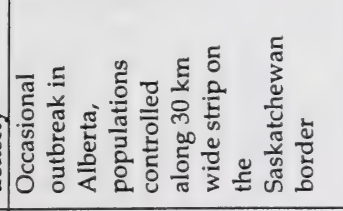 & 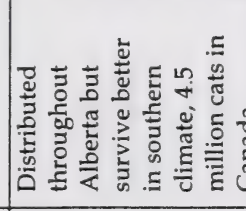 & 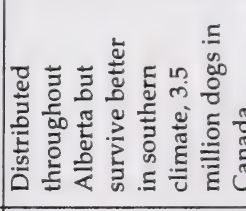 & 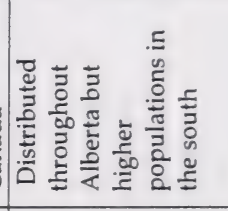 \\
\hline 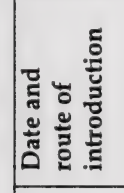 & 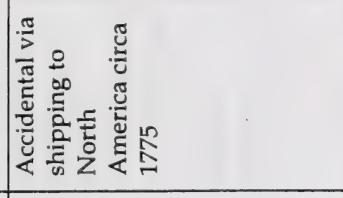 & 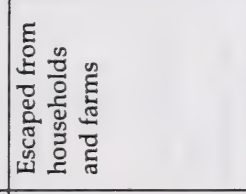 & 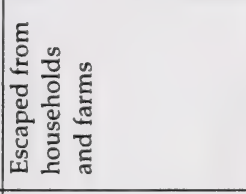 & 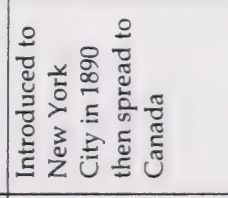 \\
\hline 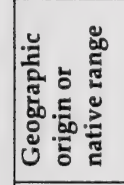 & 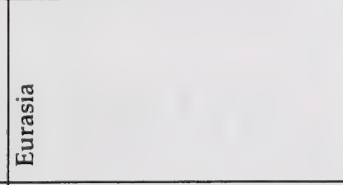 & 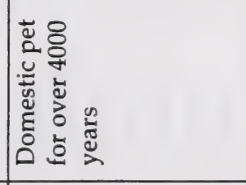 & 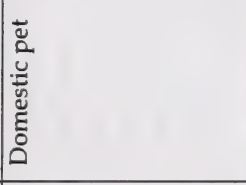 & \\
\hline 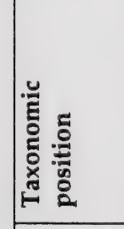 & 要 & 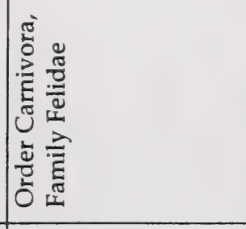 & 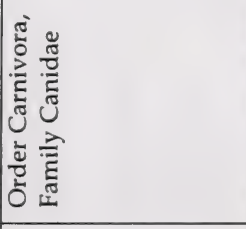 & 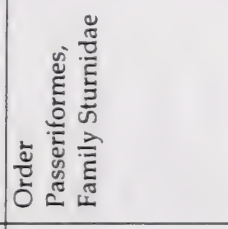 \\
\hline 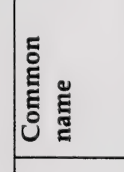 & $\mid$ & 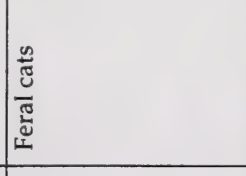 & 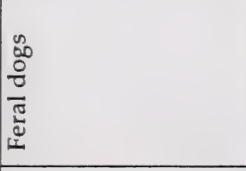 & 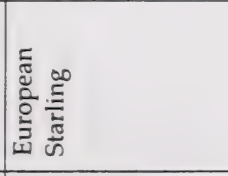 \\
\hline 总 & 逽 & 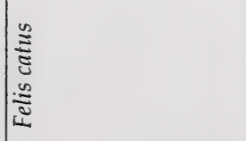 & 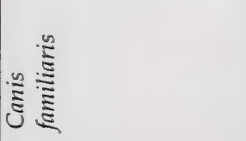 & 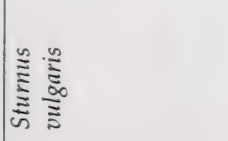 \\
\hline
\end{tabular}




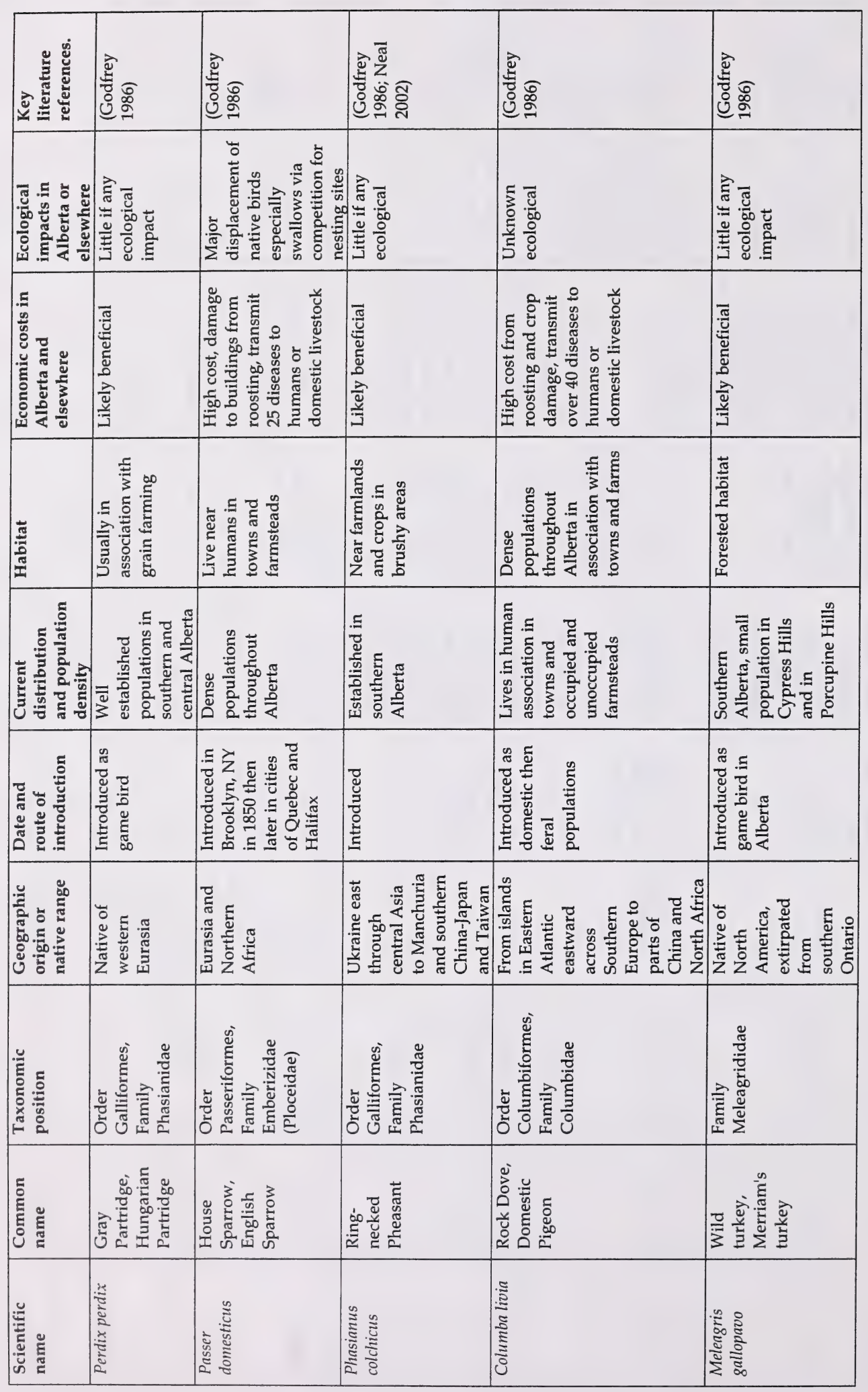




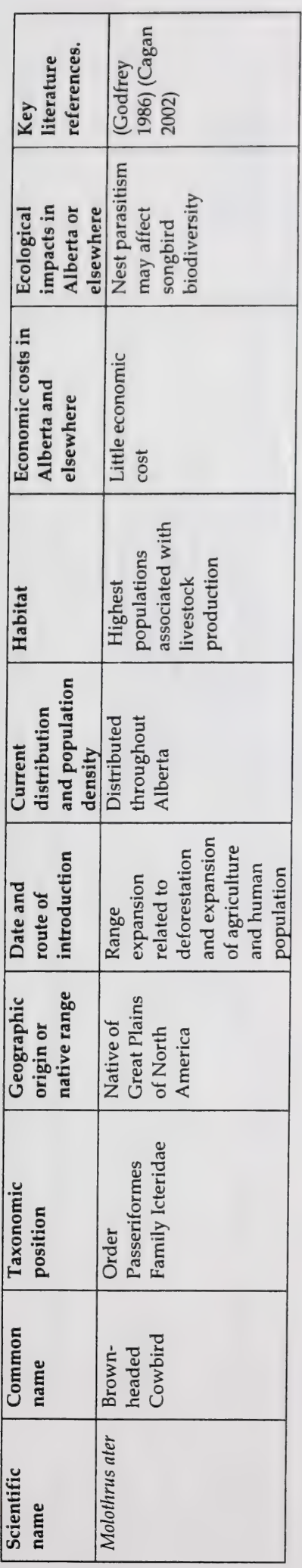




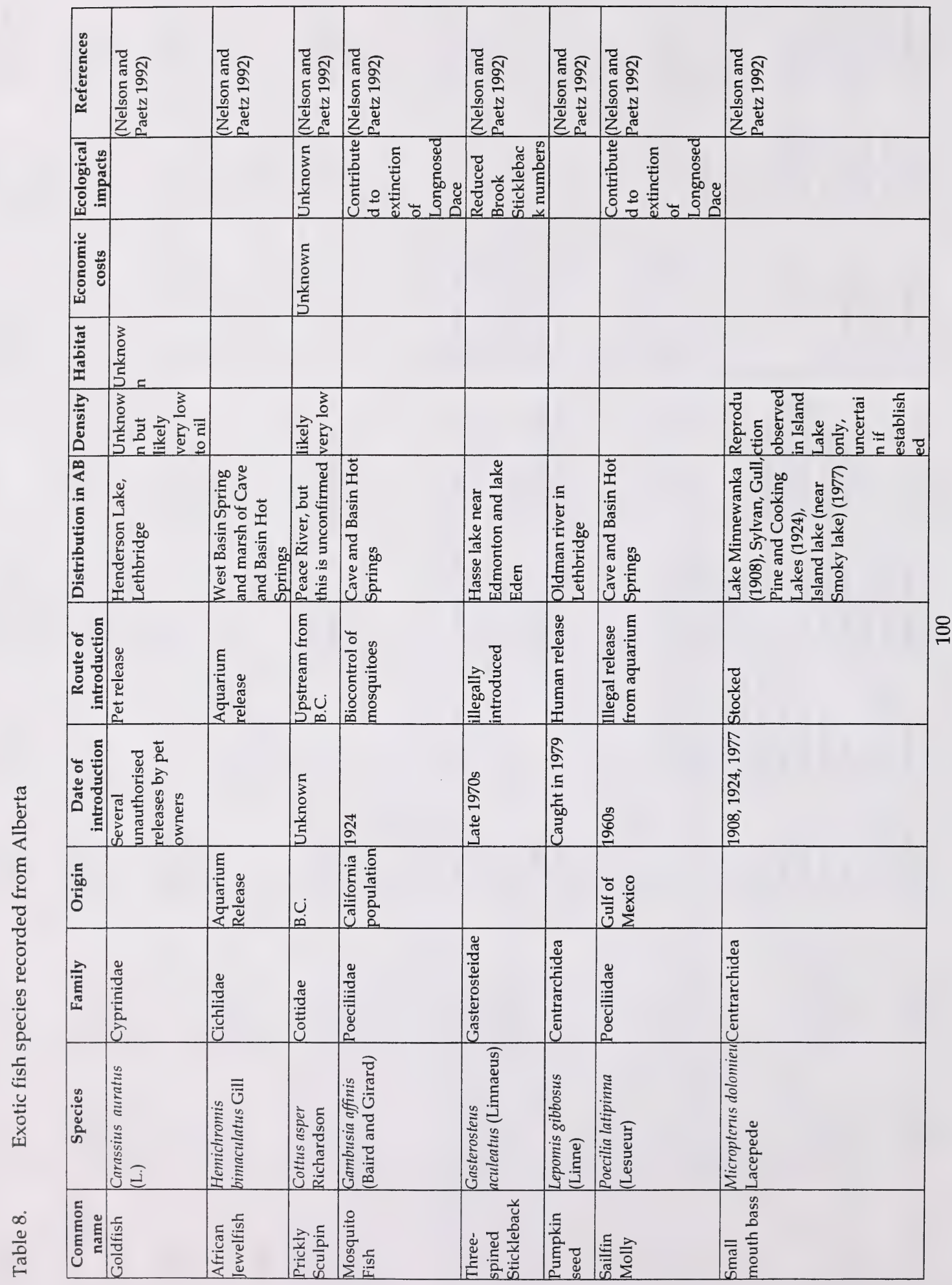




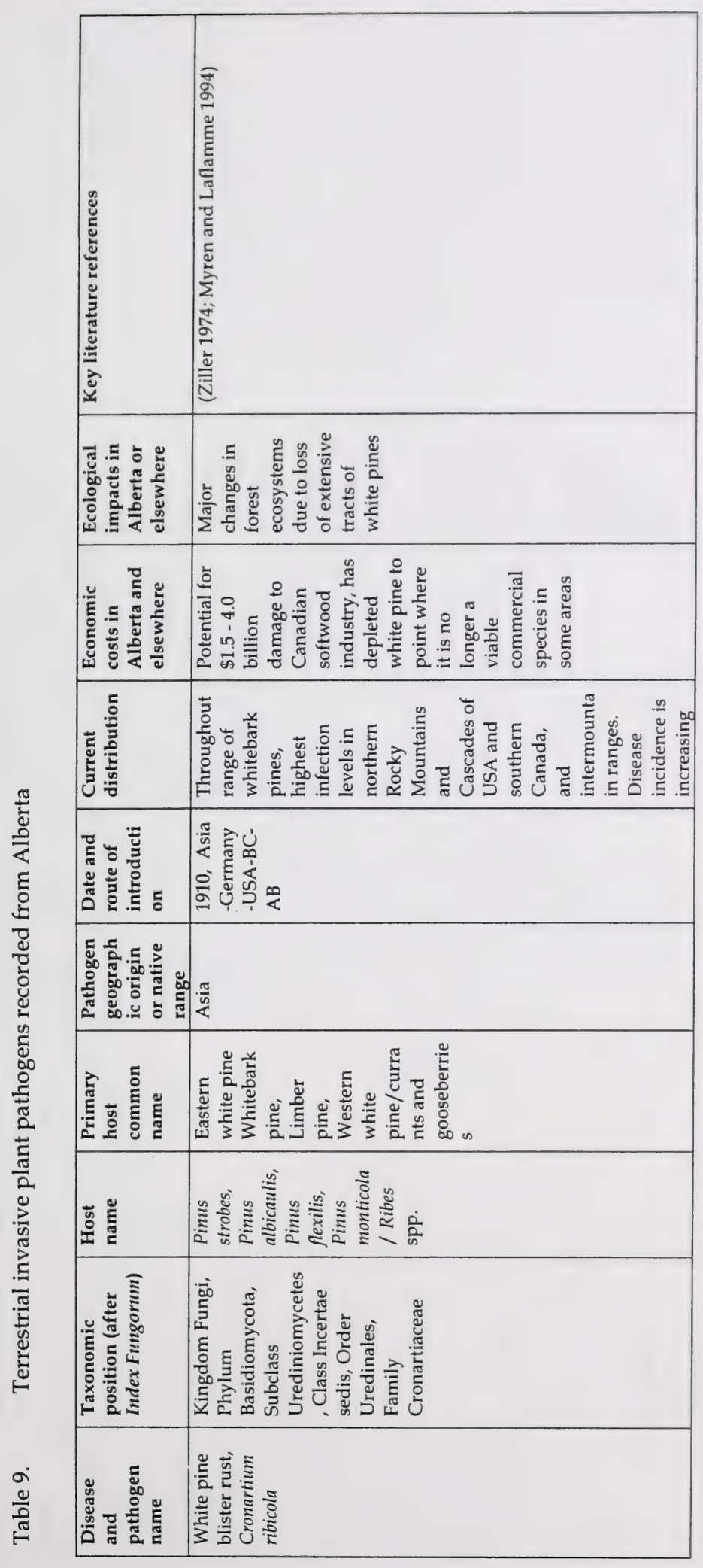




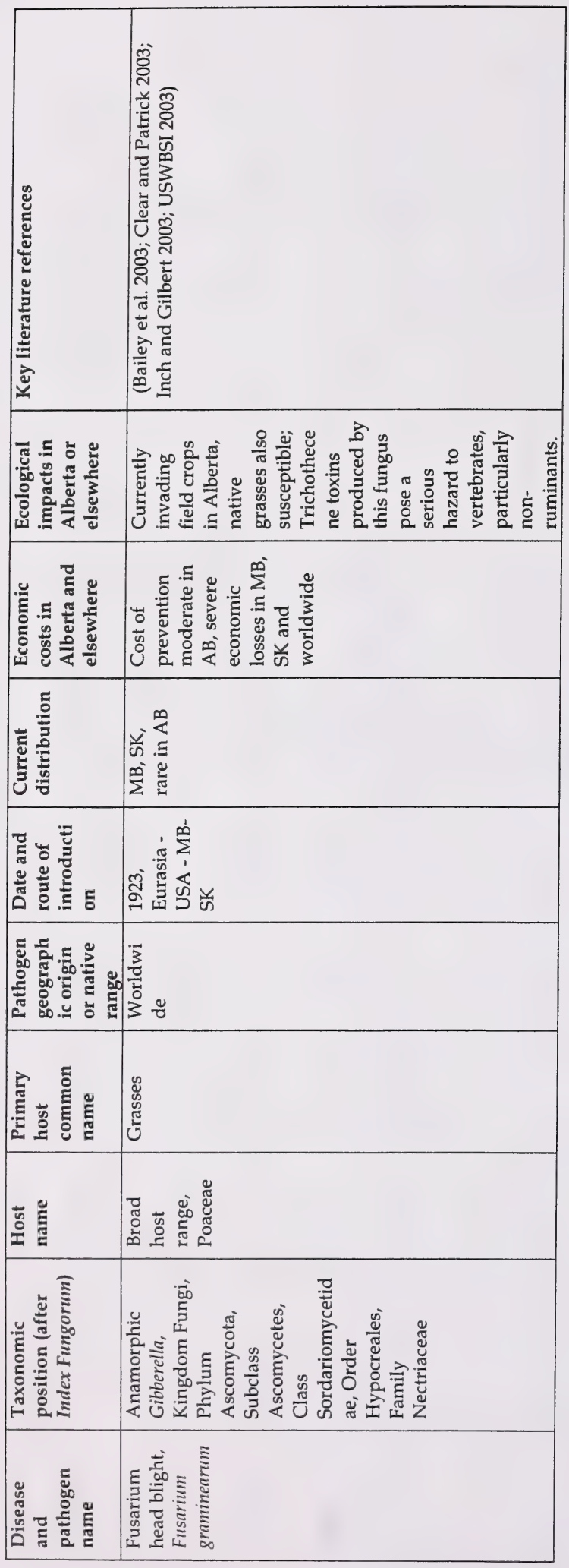

$\Xi$ 


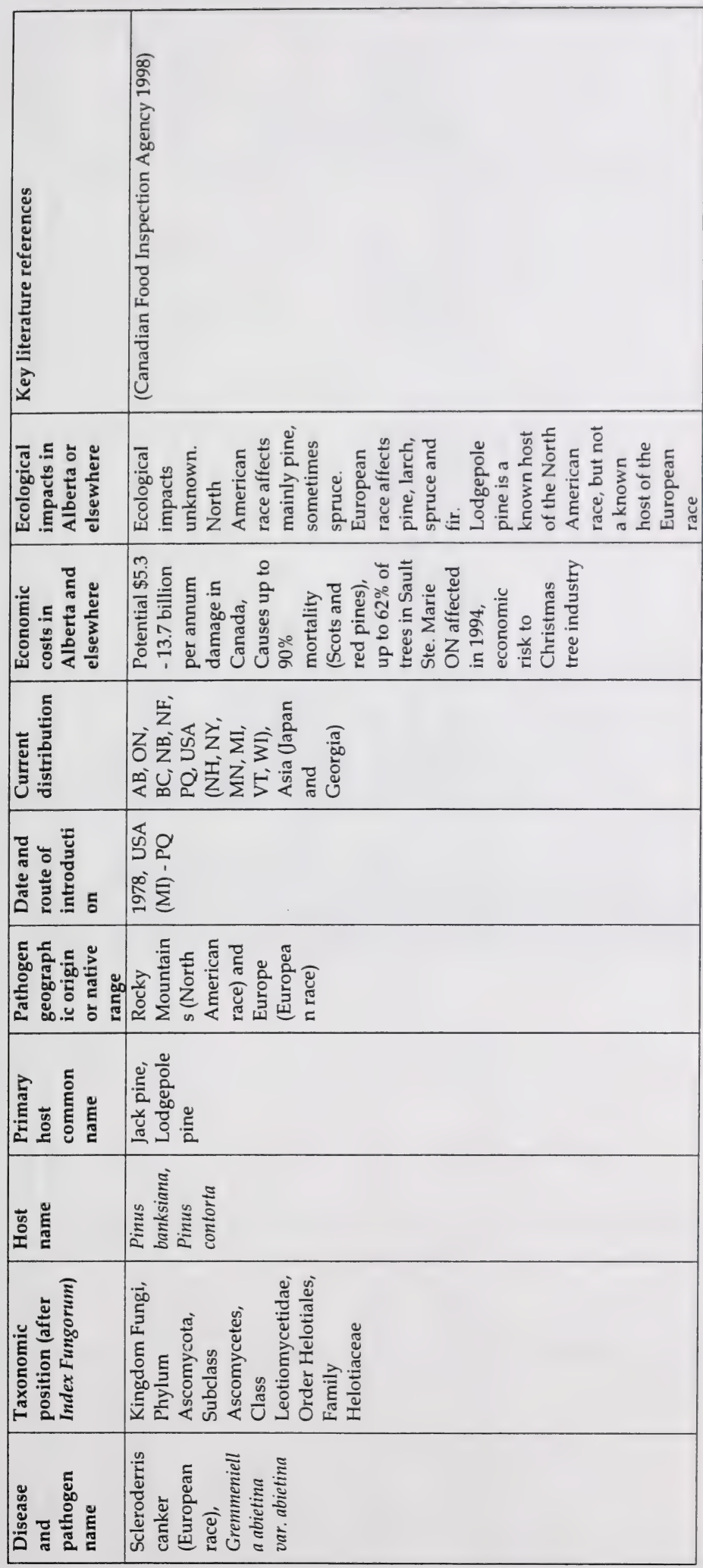




\begin{tabular}{|c|c|c|}
\hline 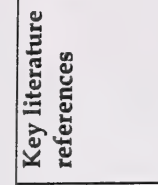 & 星 & 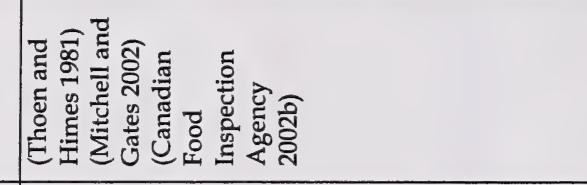 \\
\hline 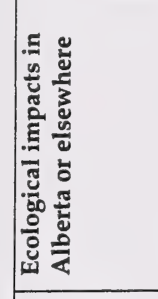 & 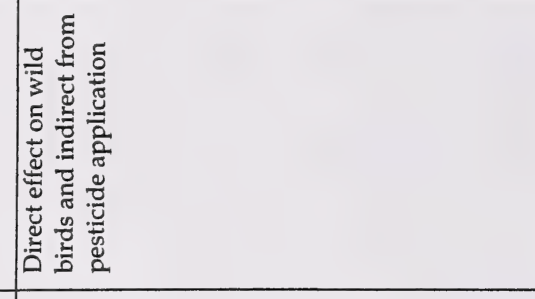 & 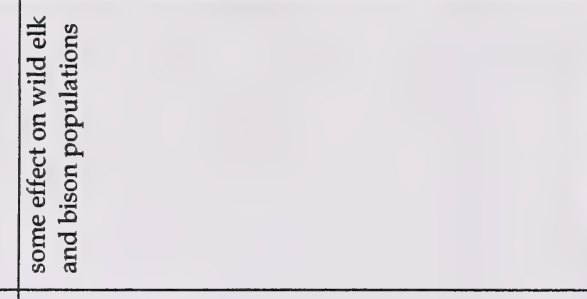 \\
\hline 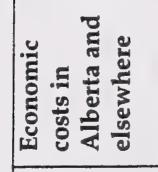 & 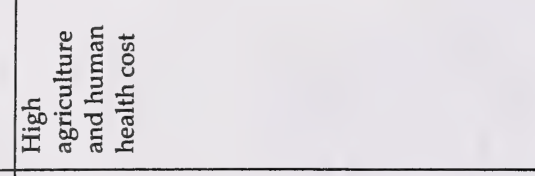 & 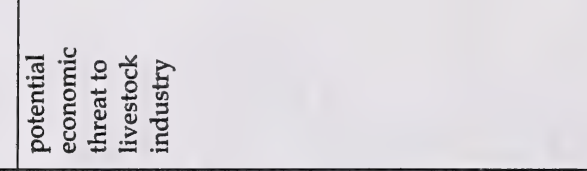 \\
\hline 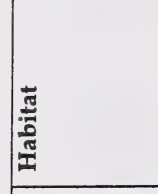 & 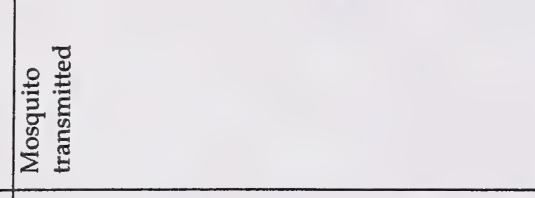 & 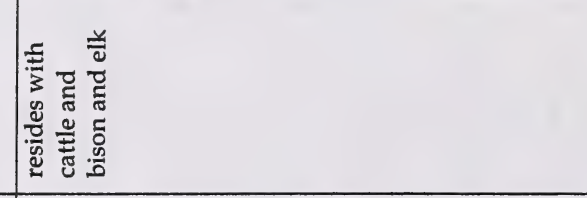 \\
\hline 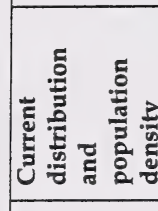 & 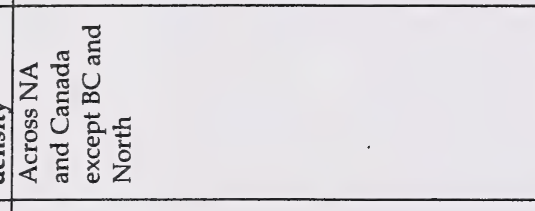 & 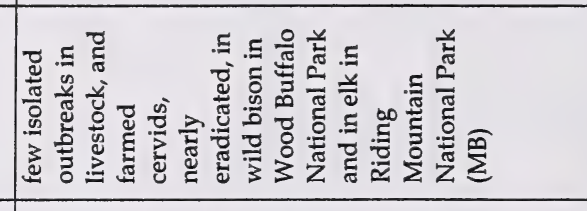 \\
\hline 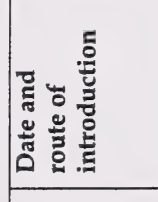 & 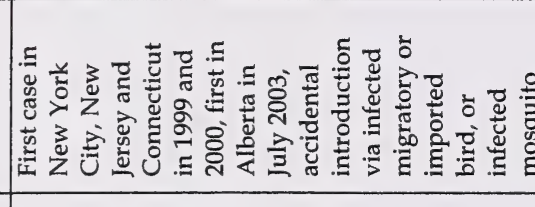 & 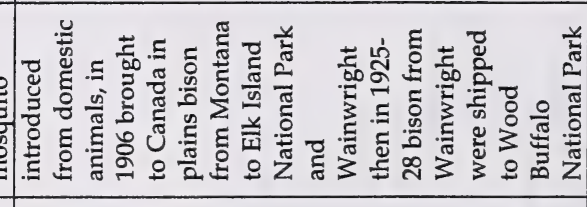 \\
\hline 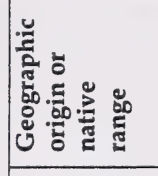 & 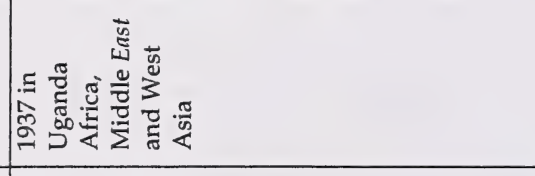 & 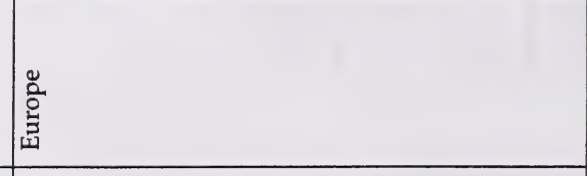 \\
\hline 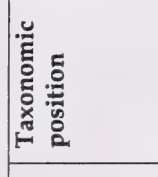 & 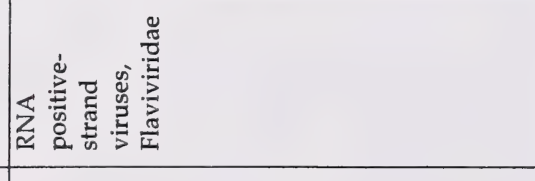 & 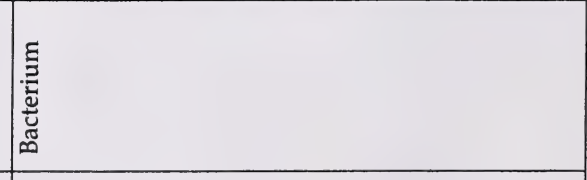 \\
\hline 总 & 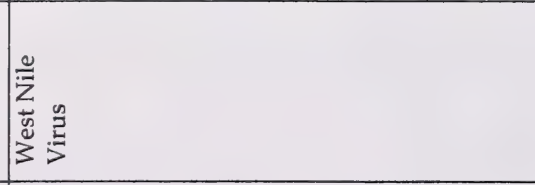 & 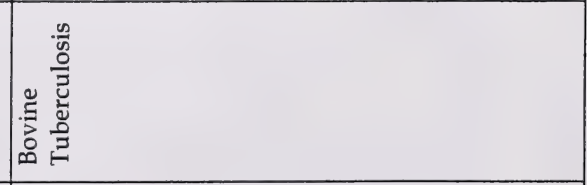 \\
\hline 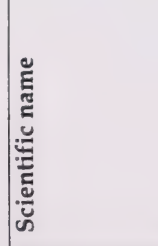 & $\frac{\hbar}{z}$ & 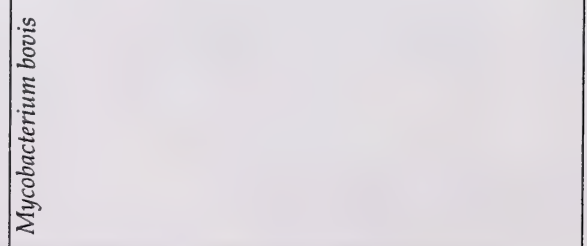 \\
\hline
\end{tabular}




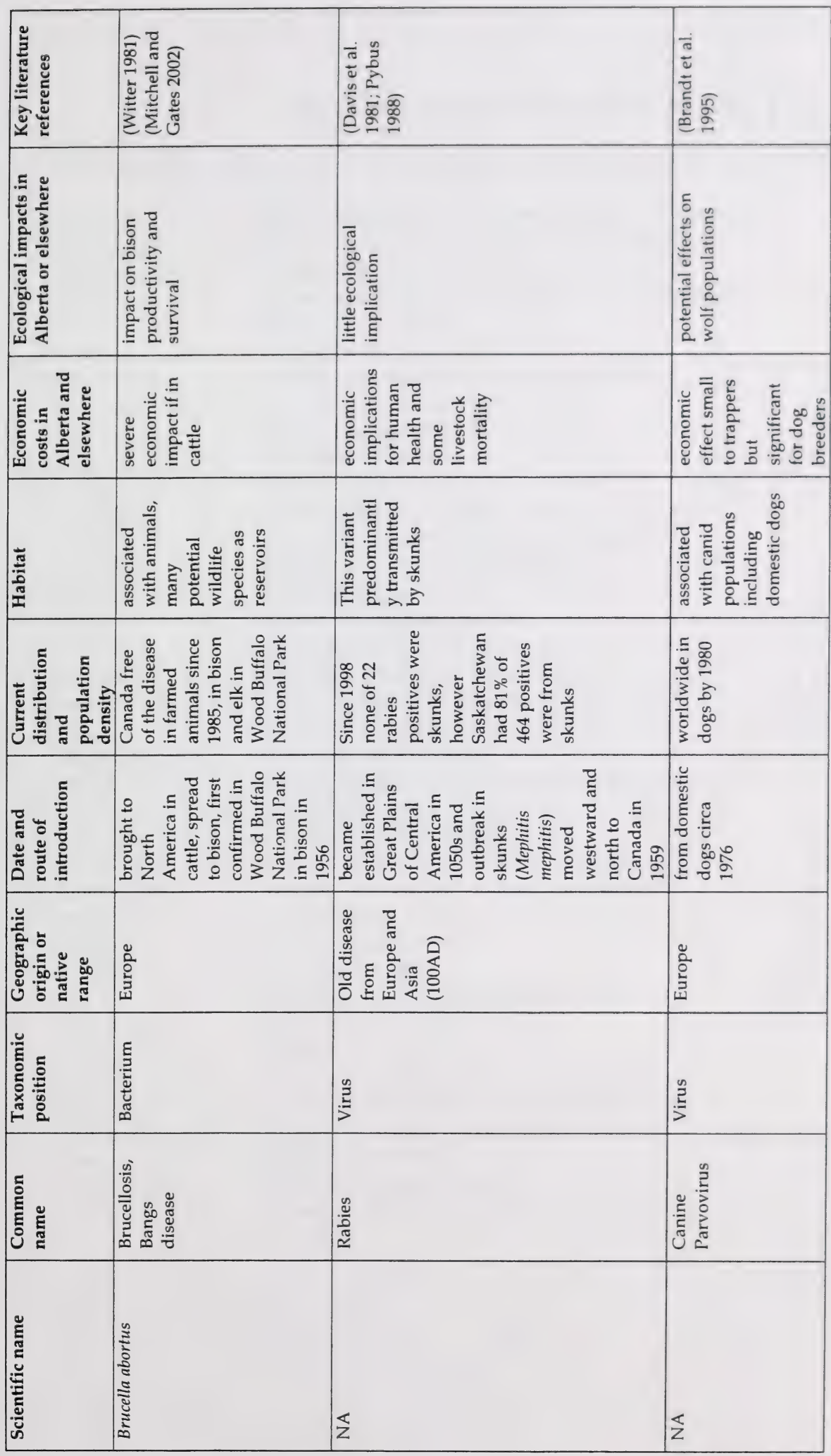




\begin{tabular}{|c|c|}
\hline 递 & 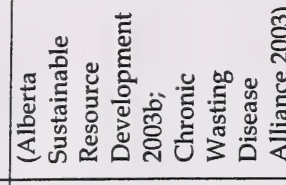 \\
\hline 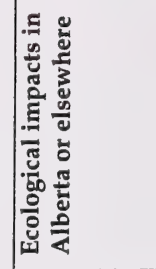 & 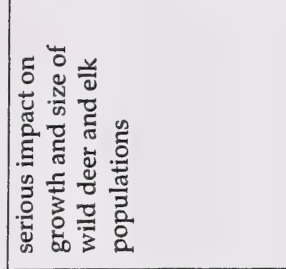 \\
\hline 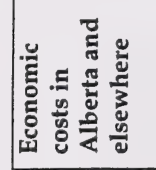 & 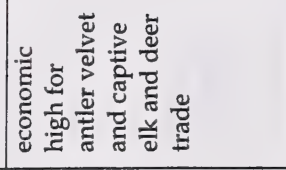 \\
\hline 苛 & 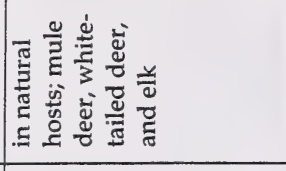 \\
\hline 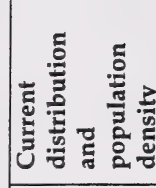 & 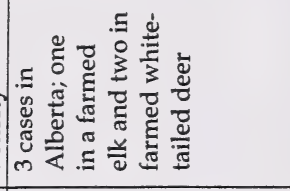 \\
\hline 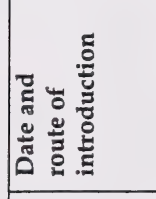 & 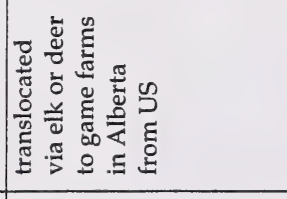 \\
\hline 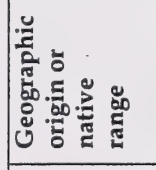 & 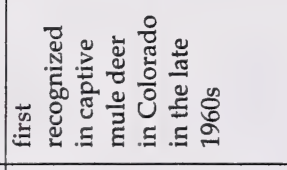 \\
\hline 莀 & 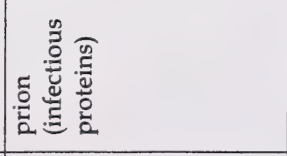 \\
\hline 总 & 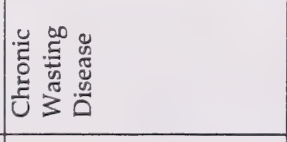 \\
\hline 苋 & ź \\
\hline
\end{tabular}




\section{APPENDIX 2: INDIVIDUALS CONSULTED}

We are grateful to all the following experts who provided information for this report:

Aasen, A.

Adams, B.

Alexander, M.

Ali, S.

Ball, G.

Bork, E.

Borutski, D.

Bouchard, P.

Cárcamo, $\mathrm{H}$.

Craig, D.

Dietzler, T.

Dosdall, L.

Ehlert, G.

Forsyth, R.

Foster-Stubbs, S.

Haber, E.

Hartley, D.

Johnson, D.

Jones, $\mathrm{M}$.

Lane, C.

Langor, D.

Norris, $\mathrm{H}$.

O'Hara, P.

Pohl, G.

Pybus, M.

Ranasinghe, S.

Roger, L.

Roland, J.

Saunders, C.

Sela, S.

Spence, J.

Sperling, F.

Sullivan, M.

Sundquist, K.

Undershultz, M.

Visser, S.

Volney, J.

Yaki, G.
Alberta Agriculture, Food and Rural Development

Alberta Sustainable Resource Development

Alberta Sustainable Resource Development

Alberta Agriculture, Food and Rural Development

University of Alberta

University of Alberta

Alberta Sustainable Resource Development

Agriculture and Agri-Food Canada

Agriculture and Agri-Food Canada

University of Alberta

M.D. of Rocky View

Alberta Agriculture, Food and Rural Development

Alberta Sustainable Resource Development

Royal British Columbia Museum

20/20 Seed Laboratories

National Botanical Services

University of Alberta

Agriculture and Agri-Food Canada

Alberta Sustainable Resource Development

Alberta Sustainable Resource Development

Canadian Forestry Service

Alberta Sustainable Resource Development

M.D. of Fairview

Canadian Forestry Service

Alberta Sustainable Resource Development

Alberta Sustainable Resource Development

WWF Canada

University of Alberta

City of Edmonton

Canadian Food Inspection Agency

University of Alberta

University of Alberta

Alberta Sustainable Resource Development

Alberta Sustainable Resource Development

Alberta Sustainable Resource Development

University of Calgary

Canadian Forestry Service

Alberta Native Plant Council 


